\author{
Banco de México \\ Documentos de Investigación
}

Banco de México

Working Papers

$N^{\circ} 2017-15$

\title{
The International Bank Lending Channel of Monetary Policy Rates and QE: Credit Supply, Reach-for-Yield, and Real Effects
}

\author{
Bernardo Morais \\ Federal Reserve Board
}

Jessica Roldán-Peña

Banco de México

\author{
José-Luis Peydró \\ ICREA-Universitat Pompeu Fabra \\ Claudia Ruiz \\ World Bank
}

September 2017

La serie de Documentos de Investigación del Banco de México divulga resultados preliminares de trabajos de investigación económica realizados en el Banco de México con la finalidad de propiciar el intercambio y debate de ideas. El contenido de los Documentos de Investigación, así como las conclusiones que de ellos se derivan, son responsabilidad exclusiva de los autores y no reflejan necesariamente las del Banco de México.

The Working Papers series of Banco de México disseminates preliminary results of economic research conducted at Banco de México in order to promote the exchange and debate of ideas. The views and conclusions presented in the Working Papers are exclusively the responsibility of the authors and do not necessarily reflect those of Banco de México. 
Documento de Investigación 2017-15
Working Paper

2017-15

\title{
The International Bank Lending Channel of Monetary Policy Rates and QE: Credit Supply, Reach-for-Yield, and Real Effects*
}

\author{
Bernardo Morais ${ }^{\dagger}$ \\ Federal Reserve Board
}

Jessica Roldán-Peña ${ }^{\S}$

Banco de México

\author{
José-Luis Peydró \\ ICREA-Universitat Pompeu Fabra
}

\author{
Claudia Ruiz \\ World Bank
}

\begin{abstract}
We identify the international credit channel of monetary policy by analyzing the universe of corporate loans in Mexico matched with firm and bank data, and by exploiting foreign monetary policy shocks in a country with a large presence of European and U.S. banks. The robust results show that a softening of foreign monetary policy increases the supply of credit of foreign banks to Mexican firms. Each regional policy shock mainly affects supply via their respective banks, in turn implying strong real effects, with lower elasticities from QE. The impact of low foreign monetary policy rates and expansive QE is stronger on local borrowers with higher ex-ante loan rates -reach-for-yield- and with higher ex-post loan defaults, thus suggesting an international risk-taking channel of monetary policy. All in all, the results suggest spillovers of core-countries' monetary policies on emerging markets, both in the foreign monetary softening and tightening part.

Keywords: Monetary policy, financial globalization, quantitative easing (QE), credit supply, risk-taking, foreign banks.

JEL Classification: E52, E58, G01, G21, G28.
\end{abstract}

Resumen: Identificamos el canal de crédito internacional de la política monetaria mediante el análisis del universo de préstamos corporativos en México en conjunto con datos de firmas y bancos, y explotando choques de política monetaria internacional en un país en el que la presencia de bancos europeos y estadounidenses es importante. Los resultados del análisis muestran que un relajamiento de la política monetaria en el exterior aumenta la oferta de crédito por parte de bancos extranjeros a las empresas mexicanas, principalmente a través de sus respectivos bancos, implicando, a su vez, efectos reales significativos. El impacto de bajas tasas de política monetaria internacional y expansiones en el QE es mayor para las empresas que enfrentan tasas de interés ex-ante más altas y mayores tasas de impago ex-post, sugiriendo la existencia de un canal de toma de riesgos internacional de la política monetaria.

Palabras Clave: Política monetaria, globalización financiera, flexibilización cuantitativa, oferta de crédito, toma de riesgos, bancos extranjeros.

\footnotetext{
*Acknowledgments and important disclaimers can be found at the end of the paper.

$\dagger$ Emerging Market Economies Section. Email: bernardo.c.morais@frb.gov.

$\ddagger$ CREI, Barcelona GSE, Imperial College, CEPR. Email: jose.peydro@upf.edu.

$\S$ Dirección General de Investigación Económica. Email: jroldan@banxico.org.mx.

** DECFP. Email: cruizortega@worldbank.org.
} 


\section{Introduction}

The recent global financial crisis, as well as other previous crises, have shown that bank credit cycles have a crucial impact on the economy, that financial globalization can affect financial stability, and that monetary policy may be a key public policy tool (Bernanke, 1983; Reinhart and Rogoff, 2009; Schularick and Taylor, 2012). Strong bank credit growth, especially financed by foreign liabilities, is the most important predictor of financial crises (Jorda, Schularick and Taylor, 2011; Gourinchas and Obstfeld; 2012), which are in general accompanied by bank credit crunches and sudden stops of foreign capital (Bernanke and Lown, 1991; Calvo and Reinhart, 2000). Moreover, as argued by Rey (2013) in the annual Federal Reserve's conference in Jackson Hole, monetary policy by the Federal Reserve may have substantial spillovers in emerging markets' credit cycles, thereby generating an international risk-taking channel of monetary policy. The Fed's Vice Chairman, Stanley Fischer (2014), similarly warned about the international spillovers that both interest rate and

quantitative easing $(\mathrm{QE})$ may have, pointing out that European monetary policy also plays a key role, as European banks are strongly globalized. In emerging markets, central bankers like Raghuram Rajan (2014), Governor from the Reserve Bank of India, have been alerting about the spillovers of U.S. and Europe's monetary policy on the financial stability of their economies.

We study the international credit and risk-taking channel of monetary policy, in particular, the impact of core countries' monetary policy on emerging markets' credit cycles, risk-taking, and the associated local real effects. More concretely, we analyze: (a) whether foreign monetary policy affects the supply of credit from foreign banks to local firms; (b) whether there are real effects associated with foreign monetary policy shocks, including firm investment, employment and survival, or whether local firms are able to reduce these shocks by substituting credit with local banks or with other sources of finance; (c) whether an expansive foreign monetary policy creates an international risk-taking channel by affecting global banks' reach-for-yield incentives; (d) whether these effects depend on the type of monetary policy used, i.e., policy rates versus QE; and finally, (e) whether foreign and local banks finance differently their local credit expansion. 
Despite the importance of these questions for policy and macro-finance, the identification of foreign monetary policies on the credit and risk-taking channel by foreign banks has been elusive. This has been due to the lack of exploitation of comprehensive credit registry data, matched with firm and bank information, especially in emerging markets, with enough years to analyze monetary policy. As we explain below, a matched credit-firm dataset is necessary to identify (and analyze) credit supply, including risk-taking and reach-for-yield, as well as the associated real effects of credit supply. Moreover, foreign banks are important around the world, and even more in emerging markets and developing countries where they have around 50 percent of the market share in terms of loans, deposits and profits (see Claessens and van Horen, 2012).

We overcome these hurdles by using the proprietary dataset of the Mexican bank supervisor containing all business loans matched with firm balance-sheet information, including for example firm investment and employment, as well as bank information on ownership and funding. Importantly, the dataset includes all new and outstanding commercial loans at a monthly frequency from all banks in Mexico, as well as the relevant loan terms, including loan rates (that are absent in most credit registers around the world).

The importance of foreign banks in Mexico (notably U.S., Eurozone and U.K.) in conjunction with the exhaustive credit data (matched with firm and bank level data) makes Mexico an excellent empirical laboratory to identify the transmission of foreign monetary policy shocks - both interest rates and QE - through the credit supply of foreign banks, as well as the associated real effects on borrowers, and the reach-for-yield incentives of banks. In particular, the credit extended to Mexican firms by banks in Mexico owned by U.S. and European banks represents 58 percent of all commercial bank credit in Mexico. Furthermore, unlike most credit registries, the Mexican one does not have a minimum loan size for inclusion in the dataset. ${ }^{1}$ Overall, our dataset includes $8,268,794$ loans given by 38 banks to 169,576 firms.

\footnotetext{
${ }^{1}$ For example, in Germany the threshold is 1.5 million euros while in Italy it is 75,000 euros. This implies that loans to small and even medium size firms may not be included in those credit registers.
} 
To identify the credit and risk-taking channels of monetary policy (Bernanke and Gertler, 1995; Kashyap and Stein, 2000; Stein, 1998 and 2011; Adrian and Shin, 2011; Rey, 2013), we analyze loan-level data at the monthly frequency with borrower (or borrower*period) fixed effects. This allows us to control for unobserved (time-variant) firm fundamentals (such as investment opportunities or risk) that proxy for credit demand, given that foreign banks may lend to different types of firms (Khwaja and Mian, 2008; Mian, 2006). Since only 21 percent of all firms borrow from multiple banks in the same period, in some specifications we use firm*bank and state*industry*period fixed effects to include firms that in a given period borrow only from one bank. Note that as period fixed effects control for unobserved global shocks, identification also comes in a given month from the differential of monetary policies between Mexico, U.S., U.K., and the Eurozone. Our results also suggest strong exogeneity of firm fundamentals to bank shocks since, despite a huge increase in $\mathrm{R}^{2}$, our estimated coefficients do not change if we control for firm*period fixed effects as compared to state*industry*period fixed effects (following Altonji et al, 2005). Finally, to identify the risk-taking channel of monetary policy, we classify borrowers into high- and low-yield (based on their ex-ante loan rates) and analyze changes in credit supply, including ex-post loan defaults.

For the identification of the associated real effects, we analyze total bank credit and also total (bank and non-bank) firm-level credit availability as well as the dynamics of firm assets, net investment, employment and a proxy of firm survival due to loan defaults. Analyzing firm-level credit is key as firms could potentially minimize the international monetary policy shocks by substituting their current credit suppliers with credit from other banks or from other sources of finance. Note that for identification we need a firm matched credit register to study firm outcomes for differently affected firms by foreign banks. Furthermore, and different from papers that analyze local monetary policy on local credit conditions, we examine European and U.S. monetary policies, which are exogenous to the Mexican economy; for monetary rates, we use a measure of the Taylor rule-type shocks, 
while for QE we use the change in the balance sheets of U.S., U.K. and Eurozone central banks' as a share of GDP. ${ }^{2}$

We find the following robust results. A foreign policy rate shock affects the supply of credit to Mexican firms mainly via their respective foreign banks in Mexico: U.S., U.K. and Eurozone monetary policies impact the supply of credit to Mexican firms mostly through U.S., U.K. and Eurozone banks, respectively. Furthermore, all loan terms are significantly affected, reinforcing the supply driven channel; interestingly, though, the effects are weaker for loan rates. Overall, a 1 standard deviation reduction in foreign monetary policy rates: increases the credit volume supplied by foreign banks in Mexico by around 2.1 percent, lengthens the loan maturity by 6.7 percent, and increases the probability of future loan default (delinquencies) over the next year by 9.8 percent. $^{3}$

We also find that foreign QE has an expansionary effect on credit supply to Mexican firms. More concretely, QE originated in the U.S. and the U.K. mainly works respectively through U.S. and U.K. banks in Mexico (primarily on credit volume and maturity). Moreover, an increase in foreign QE is related with a rise in loan defaults from Mexican firms to foreign banks over the following year. However, we find that even though these non-standard monetary policies have an expansionary effect, their economic magnitudes tend to be lower than those of changes in policy rates. For instance, for US monetary policy, which have the largest economic effects, whereas a one standard deviation decrease in Fed Funds rate expands credit volume of U.S. banks by 6 percent and maturity by 9.9 percent, a one standard

\footnotetext{
${ }^{2}$ To account for additional concerns of endogeneity of foreign monetary policy rates, while controlling for foreign economic activity, we take the residual of the regression of the policy rate of a country on its GDP growth and inflation (thus proxying a Taylor rule-type shock). Apart from controlling for global shocks via month fixed effects, we also control for foreign economic activity in interactions with our main variables, as this could be a separate channel of influence, including current and expected annual GDP growth and inflation, as well as a measure of financial risk. Finally, and as an additional robustness check, we also instrument for foreign monetary policy. Moreover, it is important to note that while the Fed and the Bank of England pursued explicitly QE as a key non-standard monetary policy, the ECB main non-standard monetary policy was until 2015 the full provision of liquidity to banks (ECB (2009 and 2011)).

${ }^{3}$ Moreover, a softening of foreign monetary policy increases collateral by 5.7 percent, which could be due to higher valuation of the collateralized assets when policy is softer; our main results hold when controlling for changes in collateral. Note that we summarize the results for softening, but we do not find any statistically significant asymmetric effects, except for expansive non-standard monetary policy on higher loan defaults.
} 
deviation increase in QE raises volume by only 2.5 percent and maturity by 7.1 percent. $^{4}$ Moreover, the speed of transmission of both types of monetary policy shocks becomes weaker after 12 to 15 months. There is some heterogeneity in the speed of transmission across loan margins in the first 12 months, but effects are generally strongest between 6 and 12 months for both monetary rates and QE. The impact of monetary policy rates on loan volume and rates peaks at around 12 months; the strongest result for loan defaults is also 12 months (statistically significant in both rates and QE, though the estimated coefficient on monetary rates is higher in 6 than in 12 months).

We also analyze the implications of the changes in monetary policy at the firm level. While loan-level analysis is needed to identify the credit supply, including risk-taking, firm level data is necessary to analyze both substitution of different sources of finance and the associated real effects. ${ }^{5}$ We find that the international monetary policy channel has significant real effects, with stronger elasticities from monetary rates than QE. In particular, a softening by one standard deviation of foreign monetary rates leads to an increase of: 1.5 percent of total bank credit volume, 4.9 percent on average loan maturity, 5.3 percent of future default rates, 1.2 percent in all firm liabilities, 0.5 percent in net investment, 0.4 percent in employment, and 1 percentage point in the probability of firm survival. ${ }^{6}$ Instead, a softening

\footnotetext{
${ }^{4}$ Results for QE are stronger though, the lower the CDS of the sovereign where the foreign bank is headquartered, which may explain why for some results, QE elasticities are lower than the results on interest rates, especially for Euro area banks that suffered the sovereign debt crisis. Moreover, as the next paragraphs will show, results for QE are also stronger in the high-yield segment of firms that were paying higher ex-ante interest rates.

${ }^{5}$ Importantly, the loan level regressions show that controlling for firm*month fixed effects provides very similar coefficients to controlling only for firm and state*industry*month fixed effects - i.e., results suggest that both specifications control similarly for unobserved borrower fundamentals despite a very different $\mathrm{R}^{2}$, which further suggest strong exogeneity of firm fundamentals to bank shocks following Altonji et al. (2005). Therefore, the firm-level regressions, where we cannot include firm*period fixed effects but we can include firm and state*industry*period fixed effects, can be interpreted as providing the credit availability channel. Similarly, results at the loan level are very similar for exporters versus non-exporters, proxying them by firms in either tradable vs. non-tradable industries following Mian and Sufi (2014), or in northern versus southern states, since the northern states have substantially more economic relations with the U.S. (INEGI (2014)) as well as a larger share of exports to GDP (39 percent compared to 12 percent).

${ }^{6}$ Bank-firm relationships are highly persistent, with only 9 percent of firms switching their main bank from one year to the next. Therefore, firms are affected by shocks to the banks they were dealing with in the previous period, and hence by the monetary policy affecting those banks. In addition to defaults (delinquencies) at the loan level, we also analyze a proxy for firm survival due to credit defaults, i.e. firms that disappear after they had loan defaults.
} 
of one standard deviation in QE increases future defaults on total bank credit at the firm-level by 6.5 percent but without overall significant real effects. ${ }^{7}$

Finally, expansive monetary policy leads to important heterogeneous effects of credit supply. Quantitative effects of the international channel are strongest to local corporate borrowers with higher ex-ante loan rates - proxying for reach-for-yield - with foreign banks engaging more in this risk-taking when foreign monetary policy is expansive. This finding is present along all the credit dimensions. For borrowers with high ex-ante loan rates (higher than the average), the ex-post default rates associated with a reduction of 1 standard deviation in foreign monetary policy increase by 11.7 percent, whereas for the remaining borrowers there is a 0 effect. Likewise, a 1 standard deviation expansion of QE leads to an 8.6 percent increase in the future default rate of firms with higher ex-ante loan rates, and has a substantial smaller impact on firms with lower ex-ante loan rates. Hence, greater risk-taking is associated with ex-ante observable variables (previous high loan rates) and with higher ex-post defaults. ${ }^{8}$ The overall evidence suggests an international risk-taking channel of monetary policy through foreign monetary policy rates and QE.

The overall results suggest spillovers of core-countries' monetary policies on emerging markets, both in the foreign monetary softening part (with higher liquidity and credit risk taken by foreign banks) and in the tightening part (with the negative associated local real effects in terms of lower firm total assets, net investment, employment and survival). It is interesting to note that at the bank level, we find that when foreign monetary policy is softer, the foreign subsidiaries take on more liabilities, especially foreign and shortterm, and have more loan defaults and higher expansion of the balance sheet. Hence, our results are consistent with banks taking on higher liquidity risk (partly from foreigners that are more fragile) and higher credit risk, providing more credit, to riskier ex-ante and ex-post

\footnotetext{
${ }^{7}$ Apart from the crisis effects measured by CDS (see a previous footnote) QE results are lower due to high standard errors in firm-year data; for example, results at the firm level on loan outcomes using monthly level data are all significant.

${ }^{8}$ This result is also consistent with Carabarin et al. (2016) who show that an expansive foreign monetary policy leads very large Mexican corporations to borrow more from abroad, freeing up funds for smaller borrowers.
} 
borrowers, and despite the shorter foreign liabilities, these banks lend at longer maturities in their assets.

Our key contribution is the identification of the international risk-taking and credit channel of monetary policy via foreign banks, which allows us to pin down the associated credit supply channel, including the spillovers on real effects, and the risk-taking, both exante reach for high yield and ex-post defaults. In particular, our paper contributes to the literature analyzing the international channel of monetary policy. Cetorelli and Goldberg (2012a, 2012b) provide direct evidence that global banks manage liquidity on a global scale, actively using cross-border internal funding in response to local shocks. We contribute by showing that local credit supply, including associated local real outcomes and risk-taking, is affected by foreign monetary policy shocks through foreign (global) banks. It is key to stress that foreign banks in emerging markets and developing countries have around 50 percent of the market share in terms of loans, deposits and profits (see Claessens and van Horen, 2012). Furthermore, not only do we analyze interest rate shocks but also QE monetary shocks, and thus our findings are also important given the recent policy debate about the impact of changes in U.S. and European QE/tapering and interest rate policies on the emerging markets (apart from many recent newspaper articles, see e.g. IMF/WB speech by Fed Vice Chairman Fischer (2014), Jackson Hole's Rey (2013) and a speech by Governor Rajan of the Reserve Bank of India (2014)). ${ }^{9}$

Our paper contributes to the literature analyzing the risk-taking channel of monetary policy, in particular, the international channel. Expansive monetary policy rates may promote higher risk-taking by banks and other financial institutions, as argued by an IMF Chief Economist Rajan (2005), by a Federal Reserve Governor, Stein (2013), and by Adrian

\footnotetext{
${ }^{9}$ Our paper also contributes to the literature in international finance that shows that foreign shocks affects the local economy through the banking sector (Peek and Rosengren. 2000; Mian, 2006; Acharya and Schnabl, 2010; Schnabl, 2012; Giannetti and Laeven, 2012; Popov and Udell, 2012; De Haas and Van Horen, 2012, 2013; Jeon, Olivero and $\mathrm{Wu}, 2013)$. We contribute to this literature by analyzing the foreign monetary shocks through foreign banks and quantifying the credit supply and real outcome elasticities associated to central banking policies. Note that a large part of financial globalization is through the banking sector (Kalemli-Ozcan, Papaioannou and Peydró, 2013). Moreover, as we exploit a firm-credit matched register as compared to these papers, we can pin down the real effects of credit supply and the heterogeneous risk-taking effects of credit supply.
} 
and Shin (2011) in the last Handbook of Monetary Economics, among others, and there is local empirical evidence for this channel (e.g., Jiménez et al., 2014; Altunbas, Gambacorta and Marques, 2014; Paligorova and Santos (forthcoming); Dell'Ariccia, Laeven and Suarez (forthcoming)). ${ }^{10}$ We contribute by showing the international channel (Rey, 2013; MirandaAgrippino and Rey, 2015; Bruno and Shin, 2015a, 2015b); in particular that low monetary policy rates and QE in high-income countries lead global banks to increase credit supply in emerging markets to reach for higher yield, especially to local borrowers with high ex-ante loan rates that default more (ex-post) on their loans.

Finally, we contribute to the recent literature on the credit channel of monetary policy that analyzes the impact of monetary policy at the loan level (e.g., Jiménez et al., 2012 and 2014) by showing the real effects associated to credit availability. Since these loan-level papers do not match their credit register data with firm level data, they cannot analyze the real effects associated to the bank lending channel of monetary policy. Nevertheless, real effects of monetary policy (conventional and non-conventional) on the economy, through the banking sector, may be crucial, as shown by recent theoretical papers (Diamond and Rajan, 2006, Gertler and Kiyotaki, 2010; Kiyotaki, and Moore, 2012; Gertler and Karadi, 2011). Some empirical papers using aggregate macro data have analyzed the real effects of monetary policy (Bernanke and Blinder, 1992), but as we explain in this paper (following Khwaja and Mian, 2008), loan level data is necessary for the identification of credit supply. Moreover, bank-level data (e.g., as in Kashyap and Stein, 2000) cannot identify credit supply, or the associated firm-level real effects. Therefore, another crucial contribution of our paper is to show the real effects of the bank lending channel of monetary policy with loan level data matched with firm level data.11

\footnotetext{
${ }^{10}$ See also Nuguer and Cuadra (2016) and several models of Allen and Gale (2000 and 2004) summarized in Allen and Rogoff (2011), Borio and Zhu (2008), Shleifer and Vishny (2010) and Diamond and Rajan (2012). This theoretical work suggests that expansive monetary policy through the increase in funding provided by households and other agents to banks may cause an increase in risk-taking in lending, as banks face strong moral hazard problems. A low short-term interest rate makes riskless assets less attractive and may lead to a reach-for-yield by those financial intermediaries that have short-term time horizons. Ioannidou, Ongena, and Peydro (2015) analyze risk-taking on loans over 4 years in a country, Bolivia, which is dollarized in the credit market, and do not analyze foreign banks, nor overall credit supply effects, nor real effects due to credit.

${ }^{11}$ Loan-level data is crucial to identify credit supply (and risk-taking), especially as, for example, foreign banks may lend to different type of firms, and matched firm-credit level data is needed to measure the associated real
} 
The remainder of the paper is structured as follows. Section 2 presents the empirical strategy, including the data, institutional details, and econometric equations we run. Section 3 presents and discusses the results, and Section 4 concludes.

\section{Empirical Strategy}

In this section, we present the empirical strategy to identify the impact of foreign monetary policy on local credit supply by foreign banks, and the associated risk-taking and real effects. We discuss the data and the institutional details, along with the empirical identification, and the associated econometric equations we run at the loan-, firm- and banklevel.

In our empirical analysis we use three main datasets. The first dataset has supervisory monthly information at the loan level on commercial bank lending. The second dataset contains balance-sheet and income statement information from non-financial firms at the yearly level, while the third main dataset has supervisory aggregate monthly information at the bank level, including balance sheet and income statements. Overall, the supervisory monthly datasets span from June 2001 to December 2015 albeit with different coverages, while the yearly dataset has information until 2014. Finally, we also use macroeconomic information, including local and international monetary policy variables.

The first dataset, at the loan-level, uses supervisory information on the universe of business loans. The data comes from reports sent monthly by every commercial bank to the regulator. Reports are mandatory, updated electronically, and include detailed characteristics of all the new and continuing loans made to firms by every bank in Mexico. Moreover, all business loans, regardless of their size, have to be reported. ${ }^{12}$

effects of the credit channel of monetary policy at the firm level differentiating firms by how affected they are by foreign banks via monetary policy. Additionally, our paper also contributes to the literature by analyzing the lags of the transmission of monetary policy on loan and firm outcomes, and by analyzing the impact of monetary policy on loan rates (our results are consistent with theoretical literature that argues that banks may adjust more volumes than rates in lending, see Stiglitz and Weiss (1981) and the literature following this paper).

12 To guarantee the comparability of our results across banks, and given our focus on corporate lending, we exclude from our analysis banks that specialize in consumer lending as well as niche banking, which comprise less than 3 percent of the assets in corporate bank lending. 
For each loan, we know the issuing bank, the borrower (firm), the outstanding amount, the (annualized) interest rate, both start and ending date of the loan (maturity), the fraction covered by collateral, as well as certain firm information, such as its location, and industry. Since loans are tracked every month, we are able to see their evolution until maturity. Therefore, we observe whether the debtor obligations are being fulfilled, and in case they are not, by how much and for how long the loan has been underperforming. To ensure the consistency of the data and to obtain real effects associated with credit, we exclude from our study loans to people with entrepreneurial activity, restricting our analysis to loans to commercial firms, as the dataset we use to study the real effects on firms only has balance sheet information for commercial firms, not on individual entrepreneurs. ${ }^{13}$

Overall, the loan-level dataset contains information on 169,576 firms and 38 banks. We aggregate the observations at the firm-bank-month level, which we define as a "loan", ending up with $8,268,794$ observations. For the vast majority of variables, we aggregate individual loans using a weighted average by loan volume; the only exception is loan volume, which is the sum of the value of all outstanding loans that a firm has from a certain bank in a given month. Table 1 presents the summary statistics of our main variables of interest: loan volume, maturity of the loan, fraction of the loan covered by collateral, loan interest rate and average default rate. The variable loan volume corresponds to the sum of the value of all outstanding loans of a firm from a certain bank in a given period. The average credit volume is MXN 2,244,000 (roughly USD 172,000), while the median loan is close to USD 30,000. ${ }^{14}$ The median loan interest rate and loan maturity are 15 percent and 36 months, respectively. Furthermore, the median loan is not collateralized, but the average collateral value is 26 percent. Finally, the variable default corresponds to the fraction of loans that are in arrears for more than 90 days (this definition follows the academic and policy literature). While the

\footnotetext{
${ }^{13}$ Individuals with entrepreneurial activity are legally defined as "personas físicas con actividad empresarial" whereas commercial firms are defined as "personas morales". Banks may change the classification of loans to individuals with entrepreneurial activity from commercial to consumption loans and vice versa, artificially moving the number of commercial loans in our data. Therefore, for identification of both credit supply and for real effects of credit, it is better to only analyze loans to commercial firms.

${ }^{14}$ Around 97 percent of the loans in our dataset are denominated in Mexican pesos. Loans in foreign currency does not alter our results in any significant way.
} 
average default rate is 7 percent, the median loan is not in default. See Table A1 in the Appendix for the exact definition of all the variables used in the paper.

The macroeconomic and policy independent variables used in our empirical analysis are also exhibited in Table 1 (summary statistics) and in Figure A1 (graphs). The Mexican monetary policy rate used is the Tasa de Interés Interbancaria a 1 Día (variable intrate-mex), while the U.S., U.K. and Eurozone policy rates are the Fed Funds rate (intrate-us), the Sonia rate (intrate-uk), and the Eonia rate respectively (intrate-euro). Considering that the Mexican economy is a small open economy highly influenced by the U.S. economy, we run an OLS regression of the Mexican overnight interest rate on the Mexican annual real GDP growth and CPI inflation, as well as on the Fed Funds rate and U.S. annual real GDP growth and CPI inflation, and use the residuals (variable intrate-mexr) in our benchmark regressions to isolate movements in the domestic monetary policy that are not explained by movements in the Mexican or U.S. economic activity. ${ }^{15}$ Similarly, we regress the overnight rates of the foreign central banks - U.S., Eurozone and U.K. - on their respective annual real GDP growth and CPI inflation. For example, the variable intrate-usr is the residual from the regression of the Fed Funds rate on U.S. annual real GDP growth and CPI inflation, proxying for a Taylorshock, and accounts for any movement in the monetary policy from the U.S. that is not related to the U.S. business cycle. Given the synchronization of the world economy, one possible concern is the multicollinearity of the monetary policies; however, as we are controlling for the business cycles, the correlations between the residual monetary policies are relatively moderate (see Figure A1 in the Appendix). ${ }^{16}$

After the Lehman failure, as U.S. and European overnight interest rates went to very low levels, especially in 2009, central banks engaged in different non-standard policies such as large scale asset purchases and unlimited lending to banks with the objective of further stimulating the economy. In our analysis, we include these policies (the variables qe-us, qe-

\footnotetext{
${ }^{15}$ As a robustness test, we have also run a specification using the residual of an OLS regression of the Mexican overnight interest rate only on the Mexican macro variables. The results are qualitatively similar.

${ }^{16}$ For example, the correlation of intrate-usr and intrate-euro is 0.38 . Moreover, the correlations up to mid-2009 - when policy rates hit the zero lower bound - are around 0.15. As a robustness test, in Table A7 in the Appendix, we replicate our results using that subsample.
} 
$u k$ and qe-euro) as the yearly real change of the balance sheet of the central banks as a share of GDP to account for all the different non-standard policies across the core central banks. All three central banks increased sharply their assets holdings in the third quarter of 2008, by around 8 to 10 percent of GDP, nevertheless, going forward these programs exhibited different purchasing patterns (see Figure A1 in the Appendix and Table 1). While the Federal Reserve, and in smaller scale the BoE, maintained their purchasing rate for a full year through the third quarter of 2009, the ECB sharply decreased its buying rate by early 2009. These differences are important for identification. Later, in the second half of 2010, the Federal Reserve boosted its program (dubbed QE2), while the BoE and the ECB only increased their purchasing programs by the second half of 2011 (the ECB introduced the 3-year LTRO in December 2011). Since 2013 there has been further divergence between central banks, while for example the Fed pursued tapering (reduction in the buying of assets), the ECB started TLTROs and QE. Overall, and since the start of the financial crisis, the Federal Reserve, the ECB and the BoE expanded their balance sheet as a share of GDP by an average of 15 percentage points, but with significant differences in intensity and direction over the different years.

Table 1 also presents indicator variables on whether the loan is from a Mexican, U.S., U.K. or Eurozone owned bank (variables bank-mex, bank-us, bank-uk and bank-euro, respectively). 39 percent of loans are from Mexican banks, followed by Eurozone banks, concentrating 32 percent of loans. U.S. and U.K. banks account for around 15 and 13 percent of the loans respectively. Additionally, in some specifications we include period or borrower*period fixed effects to exhaustively control at the monthly level for unobserved time-varying global shocks. Apart from controlling for global shocks via month fixed effects, we also control for foreign economic activity in interactions with our main variables, as this could be a separate channel of influence, including annual real GDP growth and CPI inflation as well as the sovereign CDS as a measure of financial risk.

The second main dataset used - Orbis - contains information on the balance sheet and income statement of the borrowing firms at the yearly level. We use this dataset to examine whether movements in foreign monetary policy have real effects on firms. To do 
so, we aggregate our credit dataset to one observation per firm and year. Table 1 presents the summary statistics of the firm-year level data set. The first variable, loan volume ${ }^{Y}$, corresponds to the sum of the value of all outstanding bank loans that a firm has in a given year from all the different banks. The variable loan maturity ${ }^{Y}$ is the average maturity of all bank loans of a firm in a given year, weighted by loan volume. Similarly, the variables loan collateral $^{Y}$, loan rate $^{Y}$ and loan default ${ }^{Y}$ correspond to the weighted averages of the collateral, interest and default rates of all bank loans of a firm in a given year, again weighted by their respective loan volume. Finally, the variable exit ${ }^{Y}$ is an indicator variable that takes the value of 1 if a firm with loan default drops from the loan-level dataset in a given year until the end of the sample proxying for firm closure. Combining the credit information with Orbis results in a significant loss of observations, since information of many firms in Orbis is missing. Nevertheless, we successfully match around 14,563 firm-year observations, with information on firms' total assets, fixed-assets (whose variation provides net investment), total employment, as well as total, current and non-current liabilities to check for other sources of firm finance. The vast majority of firms in Orbis, around 98 percent, are non-listed firms. Using the employment information from the loan-level data we find that the Orbis sample is not very different from the universe of firms (see Table A5 of the Appendix) though it is biased towards larger firms. Moreover, in Table A19 in the Appendix, we show that the results on real effects are stronger for smaller firms. Therefore, our results by using Orbis for the firm balance-sheet variables are a lower-bound estimate of the real effects of the average firm in Mexico.

To identify the real effects at the firm level, we aggregate information at the firmyear level, and therefore weigh the monetary policy of each country (both standard and nonstandard) by the share of the loans that a firm had with banks from this country in the previous year. The intuition is as follows: if a firm borrows only from one bank (say an U.K. one), then the most relevant monetary policy affecting the firm's outcomes through the bank lending channel should be the U.K. one. In other words, assume that in the previous year 40 percent of a firm's debt was obtained from U.K. banks and 60 percent from Mexican banks. If firm-bank relations are persistent, which in our dataset they are, then the most relevant 
monetary policies for this firm are from the U.K. (with a 0.4 weight) and Mexico (with a 0.6 weight). ${ }^{17}$

For each firm, the variable intrate ${ }^{Y}-$ mexr $^{*}$ share $^{Y}$-mex refers to the annual Mexican monetary policy times the share of bank credit that a firm had with Mexican banks in the previous year. Similarly, the variable intrate ${ }^{Y}-\operatorname{fgnr}^{*} \operatorname{share}^{Y}-f g n$ is the annual average of the U.S., U.K. and Eurozone monetary policy rates, weighted by the share of debt that a firm had with U.S., U.K. and Eurozone banks, respectively, times the share of foreign loans in the previous year. These aggregate monetary policy variables allow us to investigate whether firms with higher shares of credit from banks of a particular country are more vulnerable to changes of the monetary policy of that country. ${ }^{18}$ If firms can switch banks at no cost, then their past banking relationships should not impact their current or future real activity following a particular monetary policy shock, since they could smooth it by switching to other banks or to other sources of financing. However, if switching banks is costly, the impact of, say, a U.K. monetary policy shock (through U.K. banks) can have real effects on outcomes of Mexican firms' that are dependent on U.K. banks.

The third main dataset has monthly aggregate information on the banks' balance sheets, as well as information on their income and financial statements. We use this dataset to analyze the banks providing the commercial loans, to control for their characteristics, and also to test how the different sources of bank funding are affected by international monetary policy shocks. While there have been 38 commercial banks operating in Mexico during the period we analyze, the banking system has been dominated by five large banks concentrating 72 percent of total assets, which is common in most countries. Four of these banks are foreign-owned subsidiaries of major international banks from the U.S., U.K. and the Eurozone, with one, one and two banks respectively. The remaining banks are mostly

\footnotetext{
${ }^{17} \mathrm{We}$ find that bank-firm relationships are indeed very sticky, with only 9 percent of firms switching their main bank from one year to the next. Furthermore, persistence of bank-firm relations is not different across foreign and domestic banks (Table A6 in the Appendix). Regarding the switching determinants, we find that switching rates are positively related with firm size and with the number of bank relations of a firm, and negatively related with loan's duration and volume. Somewhat surprisingly, if we define small (large) firms as those with fewer (more) than 50 employees (as defined by Beck and Demirguc-Kunt (2006)) we find that the switching rates are somewhat similar at 8 and 11 percent respectively.

${ }^{18}$ For convenience, we will refer to the Eurozone as a country.
} 
domestic and represent a very heterogeneous group that focuses on different segments, such as corporate and consumer lending as well as niche banking.

Table A2 in the Appendix presents some summary statistics of all the commercial banks in our sample. The top half of the panel displays common bank measures such as total assets, liquidity and capital ratios as well as return on assets, while the bottom half exhibits the fraction of commercial loans that go into each sector. The Mexican banking system as a whole is profitable, liquid and well capitalized with average returns on assets of 1.0 percent and average returns on equity of 12.9 percent from 2001 to 2015. For comparison, during the same period the average returns on assets for U.S. banks were 1.0 percent while their average returns on equity were 10.4 percent. Lastly, the remaining columns of the Table present the statistics of the largest five banks, divided by the country of their parent bank. As highlighted in the Table, compared to the largest foreign banks, the characteristics of the largest Mexican bank are roughly within the range. Our results moreover go through if we only analyze the five largest banks in Mexico (see e.g. Table A13).

Apart from banking, capital markets in Mexico are substantially small and used exclusively by the largest corporations (Carabarin, de la Garza and Moreno (2016); IMF, 2012). Furthermore, shadow banking has grown as an alternative form of financing for firms over the last decade, albeit from a very low base. By 2014, the assets from the shadowbanking sector, defined as financial entities not subject to traditional banking regulation, represented 16 percent of Mexico's GDP, compared to 42 percent for the banking industry (Banco de Mexico, 2014). ${ }^{19}$ Therefore, and even though Mexico is a bank dominated economy, we further analyze in this paper the substitution of bank credit with other sources of liabilities for firms, in particular total firm liabilities, as well as current and non-current ones.

\footnotetext{
19 In Mexico shadow banks comprise brokerage firms, multiple purpose financial companies (Sofomes), investment funds, companies or entities granting all kinds of loans (e.g. auto financing companies or those issuing non-bank credit cards), together with entities issuing asset-backed securities or securitizations, including local exchange traded funds (ETFS), development capital certificates (DCCS) and infrastructure and real estate trusts.
} 
Finally, to understand whether banks engage in reach-for-yield as monetary policies become more expansive, we split our sample in two, depending on the previous (ex-ante) loan rates firms paid in the previous quarter. More concretely, for each period we calculate the average loan interest rate charged to all Mexican firms, weighted by loan volume. We then define firms that are above (below) this threshold to be high-yield (low-yield) firms. The loan characteristics of these two groups are displayed in Table A3 in the Appendix. Lowyield firms pay lower interest rates, by definition, and have substantially higher collateral rates and lower default rates as compared to high-yield firms, thus suggesting that they are indeed less risky.

As discussed earlier, we use regressions at the loan-month level (more concretely, firm-bank-month level) to identify changes in the credit margins of firms, and regressions at the firm-year level to examine changes in firms' real effects and credit substitution. We first discuss the loan-level econometric equations and then the firm-level ones.

\section{A. Outcomes at the loan level}

Our main objective is to understand whether foreign monetary policy shocks are transmitted to local firms through banks from the countries where the shocks occur (e.g., Eurozone monetary policy transmitted by Eurozone banks in Mexico through their lending to Mexican firms). To do so, we investigate whether credit availability of a given bank is especially affected by changes in the monetary policy of the country where the bank is headquartered. As borrowers from different banks can be different, we need to analyze firmbank-month data for identification.

Our baseline specification is given by equation 1 . This specification consists of an OLS regression relating the credit outcome of each firm-bank pair in a given month to the quarterly-lagged monetary policies of each of the four countries examined (both traditional and non-standard monetary policies). ${ }^{20}$ Each monetary policy is also interacted with an

\footnotetext{
${ }^{20} \mathrm{We}$ also perform different lags of monetary policy, other than a quarter. As robustness tests, instead of using the monetary policies with one-quarter lag, we ran specification (1) using the alternative monetary policies with lags up to 24-month months. Up to 12 months all these tests yield qualitatively similar results, but slightly different quantitative results. After 12-15 months, the coefficients start to become statistically indifferent from zero.
} 
indicator variable that equals one if the bank providing the loan is headquartered in this country and zero otherwise. For example, a loan given by a UK bank will have 0 for all the dummies except for UK monetary policy.

$$
\begin{aligned}
& y_{i, b, t}=\rho+\sum_{\text {country }}\left[\alpha_{\text {country }} \text { intrate-country } t_{t-3}+\beta_{\text {country }} \text { intrate-country }{ }_{t-3} * \text { bank-country } y_{b}\right]+ \\
& +\sum_{\text {country }}\left[\gamma_{\text {country }} q \text {-country }{ }_{t-3}+\delta_{\text {country }} q \text { e-country }{ }_{t-3}{ }^{*} \text { bank-country }{ }_{b}\right]+\mathrm{X}_{\mathrm{b}, \mathrm{t}}+\varepsilon_{\mathrm{i}, \mathrm{b}, \mathrm{t}}
\end{aligned}
$$

In equation (1), $y_{i, b, t}$ corresponds to the credit outcome $y$ of firm $i$ with bank $b$ at month t. Credit outcome $y$ refers to $\log$ (loan volume), $\log$ (loan maturity), collateral rate, loan rate or the fraction of loans in default 12 months ahead. ${ }^{21}$ The regressor intrate-countryi,t-3 is the one-quarter lagged monetary policy rate of a country $=\{U . S .$, U.K., Euro, Mex $\}$, whereas bank-country is an indicator of bank nationality. ${ }^{22}$ The regressor qe-country $y_{i, t-3}$ measures the yearly real change in the balance sheet of the central bank (over its GDP) of a country in the previous quarter $(t-3)$. Moreover, additional controls included in $X_{b, t}$ are the one-quarter lagged annual growth rates of all countries' GDPs and CPIs (all in levels and interacted with the indicator variables of banks' nationalities) as well as sovereign CDS. These variables allow us to control for the business cycles, and to better isolate changes in monetary policy from other changes in economic activity. ${ }^{23}$

Equation (1) also has several fixed effects. A key challenge of our empirical strategy is that different banks may have borrowers with different characteristics, complicating the identification of the (international) bank lending (supply) channel of monetary policy. To achieve identification, we first saturate our loan-level specification with fixed effects at the

\footnotetext{
${ }^{21}$ For robustness, we also tested for the fraction of loans in default 6 and 24 months ahead. The main results hold in all specifications. Results are available upon request.

${ }^{22}$ We use the residuals of the regression of monetary policy on macro movements intrate-countryr instead of intrate-country to isolate in our analysis the monetary policy shocks from changes in rates due to business cycle movements. More concretely, to calculate intrate-mexr we use the residuals of the regression of intrate-mex on Mexican and U.S. annual real GDP growth and CPI inflation, and on intrate-us. For the remaining countries we use the residuals of the regression of intrate-country on country annual real GDP growth and CPI inflation. For simplicity, the residuals of the monetary policy regressions described above are referred to as monetary policy rates in the empirical strategy and results' sections.

${ }^{23}$ Furthermore, when we saturate the regressions with different sets of time fixed effects to control for timevarying unobservable heterogeneity in fundamentals, the macro controls are spanned by these fixed effects (including all unobserved time-varying bank fundamentals).
} 
firm*bank level. ${ }^{24}$ By doing this, we exploit the variation within the same firm and bank over time. This not only controls for unobserved (time-invariant) firm heterogeneity (industry, location, ownership), or bank heterogeneity, but also for sticky bank-firm relationships. Our identification comes from the fact that within a period, banks from different nationalities may be affected differently by the monetary policy shocks of their respective countries.

We also include in some specifications firm*month fixed effects. By doing so, we examine whether for the same firm in the same month, the loans offered by different banks depend on the monetary policy shocks of their parent countries. In this case, we control exhaustively for unobserved time-varying firm fundamentals (such as firm risk, investment opportunities and balance sheet characteristics). One drawback of the specifications that include firm*month fixed effects is that these restrict the sample to firms that in a given point in time have loans with more than one bank, which represent only 21 percent of the firms, holding 37 percent of the loans. Therefore, this exercise could bias our results since these firms tend to be larger and older. Therefore, in some specifications instead of firm*month, we use state*industry*month fixed effects to proxy for demand shocks. However, in order to determine whether differences across specifications are due to unobservables or to the sample selection of firms, we run the latter specification twice: First using all the firms in our data, and then using only firms with multiple bank relationships. As further robustness checks, we test the validity of the bank-lending channel by analyzing the impact of foreign monetary policy on different subsamples of firms, such as firms in more tradeable versus less tradeable sectors, following Mian and Sufi (2014), and firms located in the northern versus southern states (Tables A9 and A10 of Appendix). Furthermore, period fixed effects control for unobserved global shocks, and, hence, the identification also comes in a particular period from the differential of monetary policies among Mexico, U.S., U.K., and the Eurozone. Therefore, since our identification also compares lending from different foreign banks (themselves shocked by their home monetary policy), borrower selection is less of an issue. ${ }^{25}$

\footnotetext{
${ }^{24}$ Importantly, note that identification is not possible with just bank level or firm level data as different banks may lend to different type of firms. For example, foreign banks could lend to firms that tend to export more.

${ }^{25}$ For instance, we find that within the largest banks, borrowers are not statistically different. Using loan and firm level information, we find that across the largest banks (which include one domestic bank as well as banks from the U.S., U.K. and the Euro Area) borrowers have similar characteristics in terms of their bank credit
} 
Note that time fixed effects imply that we identify how foreign monetary policies affect foreign versus domestic banks in lending to the same firm (or industry-location) in the same month. Finally, to identify the risk-taking channel of monetary policy, we test equation (1) in the sample of firms with high versus low ex-ante loan yield, and analyze all credit outcomes, including (ex-post) loan defaults.

\section{B. Outcomes at the firm level}

While monetary policy shocks may be passed to firms through the bank lending channel, this may not imply a substantial real impact on firms if, for instance, they can smooth monetary policy shocks by easily switching banks, or by replacing bank credit for other sources of finance, like market debt, including finance from the shadow banking sector. Therefore, to analyze any real effects, we need to examine firm level data (matched with credit data to differentiate firms across their dependence on foreign banks, and hence monetary policy). Equation 2 presents the specification that we use to test the impact of monetary policy shocks on firms' credit and on real effects.

$$
\begin{aligned}
& y_{i, t}^{Y}=\theta+\lambda_{\text {mex }} \text { intrate }^{Y}-\text { mexr }_{t}{ }^{*} \text { share }^{Y}-\text { mex }_{i, t-1} \\
& +\lambda_{\text {foreign }} \sum_{\text {country }} \text { intrate }^{Y} \text {-country }{ }_{t}{ }^{*} \text { share }^{Y} \text {-country }{ }_{i, t-1} \\
& +\mu_{\text {foreign }} \sum_{\text {country }} q e^{Y} \text {-country }{ }_{\mathrm{t}} \text { share }^{Y} \text {-country } y_{\mathrm{i}, \mathrm{t}-1}+\epsilon_{\mathrm{i}, \mathrm{t}}
\end{aligned}
$$

The dependent variable $y^{Y}$ corresponds to: (i) the bank-credit outcomes aggregated at the firm-year level (loan volume ${ }^{Y}$ and loan maturity ${ }^{Y}$ in logs, loan collateral ${ }^{Y}$, loan rate ${ }^{Y}$ and loan default ${ }^{Y}$ ); (ii) an indicator of whether a firm with loan defaults closes down in a given year $\left(\right.$ exit $\left.^{Y}\right)$; (iii) firm total, current and long-term liabilities (liabilities ${ }^{Y}$, current $^{2}$ liabilities $^{Y}$ and non-current liabilities $^{Y}$ ); and (iv) firm total assets $\left(\right.$ assets $^{Y}$ ), fixed assets (fixed-assets $^{Y}$ ), which its variation proxies for net investment, and employment

volume and total assets (Table A4 of Appendix) and, therefore, conditional on borrowing from the largest banks, firms with loans from U.S., Eurozone or U.K. banks are not statistically different from each other and from firms with loans from the largest Mexican bank. Interestingly, we also confirm that our results of the main regressions hold for firms only borrowing from large banks, foreign or Mexican (Table A13 in the Appendix). 
$\left(\right.$ employment $^{Y}$ ). These last six variables (from Orbis) are in logs and only available at the yearly frequency, thus the main regressions for firm level are at the firm-year. ${ }^{26}$

The first covariate, intrate ${ }^{Y}$ country $_{i, t} *$ share $^{Y}$-country cot, $_{1}$, refers to the average monetary policy rate of country $=\{$ U.S., U.K., Euro, Mex $\}$ in year $t$ times the share of previous year's bank loans that a firm had with banks headquartered in that country (see also previous subsection on data and Appendix Table 1 for all the definitions of the variables).

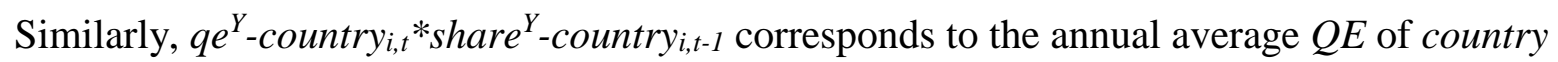
$=\{U . S .$, U.K., Euro $\}$ times the one-year-lagged share of a firm's loans with a bank from that country. Given our interest in contrasting foreign from domestic banks, we aggregate the foreign monetary policies (weighting each foreign policy by the lagged share of loans that a firm has from banks of each foreign country), intrate ${ }^{Y}-\operatorname{fgnr}_{i, t}{ }^{*} \operatorname{share}^{Y}-\operatorname{fgn}_{i, t-1}$, and $q e^{Y}$ $f g n_{i, t} * \operatorname{share}^{Y}-\operatorname{fgn}_{i, t-1}$, and we calculate two coefficients $\left(\lambda_{\text {mex }}, \lambda_{\text {foreign }}\right)$ for the monetary rates and one coefficient ( $\left.\mu_{\text {foreign }}\right)$ for the $\mathrm{QE}$.

Different from specification (1), on the left hand side we analyze all bank credit to a firm in a given year. The right hand side of this specification consists of a measure of firmlevel exposure to each monetary policy shock that is based on previous bank relationships. Given that banking relationships are sticky over time (see Table A6 for our Mexican data and Ongena and Smith, 2001, for other countries), the assumption behind this specification is that the intensity of the monetary policy shock of a particular country is proxied by the previous year share of a firm's debt with banks from that country. ${ }^{27}$

Finally, we saturate our specification with fixed effects at the firm level allowing us to control for time-invariant unobserved firm heterogeneity (such as location), and at the state*industry*year level, which allow us to control for time varying borrower fundamentals (and exploit the variation among loans from different banks to the same industry, in the same location and the same period). Importantly, as we discuss in the next section, following

\footnotetext{
${ }^{26}$ However, and for comparison purposes for the variables at the loan level we also run the regressions at the monthly level for bank credit related variables.

${ }^{27}$ In our dataset only a small fraction of borrowers ( 9 percent) change their main bank from one year to the next. See Table A6 for an analysis of the determinants of bank switching.
} 
Altonji et al (2005), the loan level regressions show that controlling for firm*period fixed effects provides very similar coefficients to controlling only for firm and state*industry*period fixed effects (i.e., results suggest that both specifications similarly control for borrower fundamentals). Therefore, the firm-level regressions, where we cannot include firm*year fixed effects, but can include firm and state*industry*year fixed effects, can be interpreted as identifying the credit availability channel.

All in all, in equation (2) we investigate if firms are able to smooth monetary policy shocks of a foreign country by switching banks or other sources of finance. If firms can easily switch banks to smooth shocks, the coefficients $\lambda_{\text {foreign }}$ and $\mu_{\text {foreign }}$ should not be statistically different from zero. Thus, this equation tests if a monetary policy shock of the country of origin of the firm's previous banks influences the firm's overall bank credit in the current year. Therefore, if changing banks is relatively easy, previous bank relationships should not be important and monetary policy shocks should have little real impact on a firm.

Since we also analyze firms' total (current and non-current) liabilities, we can check whether firms are able to replace bank credit for other types of debt, or if foreign monetary policy shocks passed through the bank lending channel have a binding effect on firms' overall liabilities. In this latter case, the coefficients $\lambda_{\text {foreign }}$ and $\mu_{\text {foreign }}$ for liabilities ${ }^{Y}$, non-current liabilities $^{Y}$ and current liabilities $^{Y}$ should be statistically different from zero. Finally, if bank credit and overall liabilities are affected, real effects stemming from foreign monetary shocks should probably exist. We test this by looking at the change on firms' total assets and employment as well as firm net investment (variation of fixed assets). ${ }^{28}$

\footnotetext{
${ }^{28}$ We further analyze bank-level data at the monthly frequency to verify whether our findings are also observed at a more aggregate level, and to understand the mechanism underlying our results. With this dataset, we examine how sensitive are the total bank assets, the various liabilities and share of credit in arrears of foreign and domestic banks to movements in monetary policies. Results are displayed in Table A8, where the regressors correspond to: intrate-fgnr*bank-fgn, which is the one-quarter lagged foreign monetary policy rate residual times an indicator variable that equals one if the bank is foreign; intrate-mexr*bank-mex, which is the onequarter lagged residual of the Mexican policy rate times an indicator variable that equals one if the bank is headquartered in Mexico; and qe-fgn*bank-fgn, which is the one-quarter-lagged yearly change in the balance sheet of its corresponding central bank over the GDP times an indicator variable that equals one if the bank is of foreign origin. Finally, we also include macro controls, namely, the annual GDP and CPI growth, a linear trend for each country/region where banks are headquartered (to allow for different growth rates of the regions examined), in addition to period and bank fixed effects.
} 


\section{Results}

This section presents our findings. We use data at the borrower-lender-month (loan) level to analyze the influence of foreign monetary policy on credit supply and risk-taking of banks. ${ }^{29}$ To study the associated real effects and credit substitution we use firm-year level data.

\section{A. Loan-Level Credit Supply Outcomes}

Panel A of Table 2 presents the results of the impact of the various foreign monetary policies on the volume of loans to firms in Mexico. The first column exhibits the baseline specification outlined in equation (1) controlling for fixed effects at the firm*bank level. As column 1 shows, the three different foreign monetary policy rates affect more strongly credit outcomes of banks from the same country. That is, each regional policy shock mainly affects lending via their respective foreign banks: U.S., U.K. and Eurozone policy affects more the lending in Mexico via U.S., U.K., and Eurozone banks respectively. ${ }^{30}$ As for the non-standard monetary policies, the QE of the U.S., U.K. and the Eurozone affects more the credit volume of firms whose loans are from U.S., U.K. or Eurozone banks respectively. In contrast, the Mexican policy rate affects the credit volume of all banks, regardless of their nationality. In other words, the overnight rate set by the Bank of Mexico has an impact on banks operating in Mexico irrespective of whether they are Mexican. ${ }^{31}$

To further control for time-varying unobserved borrower characteristics, column 2 saturates equation (1) with state*industry*period in addition to firm*bank fixed effects. Results from columns 1 and 2 suggest that even after controlling for these proxies of credit demand, the coefficients of monetary policy remain statistically and economically

\footnotetext{
${ }^{29}$ In addition, we also exploit bank-month data to further explore the mechanisms behind our loan and firmlevel results.

${ }^{30}$ Despite the numerous time-varying controls and the exogeneity of foreign monetary policy, Table A12 provides an additional robustness check of the exogeneity of the U.S. monetary policy. In that table, we instrument the Fed Funds rate (following the instruments suggested in Gertler and Karadi, 2015) for the period June 2001-November 2009, which correspond to the period in which the Fed Funds rate had not reached the zero lower bound. The results using the instrument of the U.S. policy rate are consistent with our findings. We thank Mark Gertler and Peter Karadi for sharing their data.

${ }^{31}$ This may be due to the fact that, similar to domestically owned banks, foreign subsidiaries in Mexico have substantial local retail deposits and are therefore also affected by local monetary policy. See also Table A2.
} 
significant. As mentioned above, variation in a foreign monetary policy rate affects substantially more the banks from that origin. For example, and focusing on column 2, a 1 standard deviation decrease in the Fed Funds rate raises the average loan volume of U.S. banks in Mexico by 6 percent, and a 1 standard deviation decrease in the monetary policy from U.K. (Eurozone) expands credit by an average of 4.8 (2) percent. ${ }^{32}$ It is important to stress that the coefficients of column 2 are better identified than in column 1 as in addition to firm*bank fixed effects we control for time-varying firm fundamental heterogeneity via state*industry*period fixed effects.

While the impact of QE on the supply of credit volume is not trivial, it is lower than that of standard monetary policy rates. For example, a 1 standard deviation expansion in the assets held by the Federal Reserve (relative to the U.S. GDP) increases the volume of loans from U.S. banks by 2.6 percent. Similarly, a 1 standard deviation increase in the BoE's assets expands credit by 2.1 percent. In contrast, the QE of the Eurozone becomes statistically insignificant once we control for time-varying unobservables at the state and industry level. This result showcases that analyzing credit-supply outcomes with only bank-level data would be partially misleading as lenders are not matched exogenously with borrowers. ${ }^{33}$

In column 4 we saturate equation (1) with firm*month fixed effects (in addition to firm*bank effects) and focus on variation across loans offered by different banks to the same firm in the same month. However, this specification requires firms to be holding loans from multiple banks in the same month, and these firms tend to be larger and therefore may be differently affected by monetary policy shocks. In fact, we lose more than half of the observations and some coefficients lose statistical significance. To better understand if our coefficients change due to the sample selection, in column 3 we use the same specification as in column 2, but restrict the sample to firms that in a given period have loans with more than one bank. As column 3 indicates, the coefficients that drop by half in column 4 do so

\footnotetext{
${ }^{32}$ Note that the standard deviations of interest rates and also of QE are different across the different countries' monetary policies. See Table 1.

${ }^{33}$ However, we next show that monetary policy effects are stronger when the sovereign risk of the foreign country is lower, hence the weak results of Eurozone banks in the crisis via QE reflects the higher financial risk. See also Table A14.
} 
because of the sample selection towards larger firms. Importantly, note that in column 4 the estimated coefficients are not statistically different from those of column 3 despite a substantial increase of the $\mathrm{R}^{2}$ (around 43 percentage points). This suggests that our main coefficients on credit supply shocks (foreign banks and monetary policy) are exogenous to unobserved demand proxied by (firm*month) time-varying firm unobservables and observables (following Altonji et al., 2005).

Panel B of Table 2 displays the effects of monetary policies on the three other margins of loans - maturity, collateral, and interest rate, respectively - as well as future loan defaults. On average, a 1 standard deviation reduction in foreign monetary policy translates into loans not only of larger volume, but also of longer-term maturity, and, for U.S. banks, in lower loan interest rates. ${ }^{34}$ While the supply of bank credit also increases with an expansion of foreign QE, its economic effect is lower, and is concentrated on volume. Moreover, movements in qe-us have a larger impact than movements in qe-uk or qe-euro, as it affects not only loan volume but also loan rate and maturity. More concretely, a 1 standard deviation increase in qe-us results in loans from U.S. banks that are on average 2.6 percent larger in volume, 7.8 percent lengthier, with no change on collateral and 0.3 percentage points lower loan rate.

Finally, in the last two columns we further investigate if future loan defaults (the share of loans observed in default at $t+12$ months) are influenced by the loosening of credit conditions in response to softer monetary policy. ${ }^{35}$ The results suggest that in general, softer monetary policies abroad (standard and non-standard) induce higher future loan default rates of banks from the same country or region. Furthermore, and as we show later, softer monetary

\footnotetext{
${ }^{34}$ Moreover, a softening of foreign monetary policy increases collateral by 5.7 percent, which could be due to higher valuation of the collateralized assets when policy is softer. Our main results hold when we control for changes in collateral; that is, our results are robust to controlling for the collateral as right hind side value (so even if collateral value is higher, the softening effects on the other loan outcomes are significant).

${ }^{35}$ Our measure of future default for the firm-bank relation at time $t$ is the default rate of the firm-bank pair at $t+12$, or in case the pair left our sample prior to $t+12$, the last observation available. In the empirical exercises involving the default rate at $t+12$ we only use data until December of 2014. In addition, to $t+12$ we also studied the impact on default at $t+6$ and $t+24$; results are qualitatively similar.
} 
policy induces banks to lend relatively more to firms with higher risk as proxied by higher ex-ante loan rates, which also explains our result on defaults. ${ }^{36}$

Next, in Panel C, we analyze the sensitivity of changes in the various credit margins to the timing of the monetary policy. We classify banks in domestic or foreign, and regress the different credit margins on different lags of foreign and domestic monetary policies (ranging from 3 to 24 months). In this way, the level of observation is still at the firm-bankperiod level but each firm has at most two observations per period depending on whether it has loans from both domestic and foreign banks. ${ }^{37}$

Our results first suggest that, when the benchmark one-quarter lagged foreign monetary policy rate declines by 1 standard deviation, loans from foreign banks increase their volume by 1.5 percent, lengthen their maturity by 4.8 percent and increase collateral values by 4.6 percent. Second, the impact of lagged foreign monetary policy on credit supply is somewhat persistent within a range of 3 and 12 months, and declines after 12 months (not shown). Loan volume, collateral, rates and loan rates coefficients have the maximum absolute value at the 12 month lags, while maturity and the default rate are relatively less persistent. Regarding the coefficients on QE, we also find that they increase for higher lags, especially for volume and defaults. All in all, the speed of transmission of both types of monetary policy shocks becomes weaker after 12 to 15 months, there is some heterogeneity in the speed of transmission across loan margins in the first 12 months, but effects are generally strongest between 6 and 12 months for both monetary rates and QE.

A possible concern is that the results in Table 2 could be driven by the commercial characteristics of banks and not by the specificities of foreign monetary policies. ${ }^{38}$ To test

\footnotetext{
${ }^{36}$ As a robustness check, we also analyzed asymmetric monetary policy effects, and we do not find statistically different results. The results of this test are displayed in Table A15 in the Appendix, with most of the coefficients on asymmetry being not different from zero, though in some other few cases, it may be due to lack of statistical power. One coefficient which is asymmetric is the impact of $\mathrm{QE}$ on loan defaults, which entirely comes from the expansive monetary period.

${ }^{37} \mathrm{We}$ construct the credit margins as follows: In each month, the loan volume that a given firm obtains from foreign (domestic) banks corresponds to the sum of the outstanding loans that a firm has from all foreign (domestic) banks in the period. Similarly, the other credit margins of loans from foreign (domestic) banks maturity, collateral and loan rate- as well as defaults correspond to their average weighted by loan volume.

${ }^{38}$ In Table A2 in the Appendix, we show that while foreign banks are indeed larger than the average bank, they are very similar to the largest Mexican bank.
} 
formally for this possibility, we re-estimate Panel A of Table 2, controlling for a series of time-varying bank characteristics (in addition to bank*firm fixed effects) such as bank total size, liquidity and capital ratio. Results are displayed in Table A11 of Appendix, and are not affected in any meaningful way by the introduction of these controls. Moreover, in Table A13 we find similar results when we estimate the loans of the only five large banks (the four foreign and the largest Mexican one). Furthermore, another similar concern is that the results are driven by a segmentation of customers. For example, U.K. banks may be serving firms exporting to the U.K. To control for this hypothesis, we compare our regressions for exporters vs. non-exporters, proxying them by firms in either (i) tradable vs. non-tradable industries following Mian and Sufi (2014) or in (ii) northern vs. southern states, since the northern states have substantially more economic relations with the U.S. (INEGI (2014)) as well as a larger share of exports to GDP (39 percent compared to 12 percent). Results are displayed in Tables A9 and A10, and show not different results for exporters and non-exporters for the impact of foreign monetary policy on credit outcomes via foreign subsidiaries. This result, we believe, is not surprising as the subsidiaries of foreign banks in Mexico are important across all sectors as displayed in Table A2 in the Appendix.

Finally, we use bank-level data to test whether our loan-level results are also present at a more aggregate level, and to further understand the economic mechanisms behind our findings. The results are displayed in Table A8 of the Appendix. Columns 1 and 2 corroborate our loan-level results: when foreign monetary policy becomes more expansive, the total assets and one-year-ahead credit-in-arrears of foreign banks increase relatively more. We find a similar pattern with changes of foreign QE. The next three columns provide an insight on the economic mechanisms behind our results. Compared to domestic banks, foreign banks borrow substantially more, especially from abroad, when foreign monetary policy is softer. That is, compared to domestic banks, foreign banks obtain more funds from foreign markets when foreign monetary policy is softer. Furthermore, and while not statistically significant, the economic magnitude of the coefficient of foreign monetary policy on short-term liabilities is very strong (the coefficient is high and larger than in the other margins but with substantial higher standard errors), thereby suggesting that foreign banks obtain more short-term funding 
when foreign monetary policy is softer.

All in all, our results are consistent with foreign banks taking on higher liquidity (partly from abroad) and credit risk (providing more credit and with higher ex-post defaults), and despite that the liabilities are more fragile (i.e., foreign and partially shorter), these banks lend at longer maturities in the asset side (with higher credit volume and to riskier borrowers, as suggested by the higher ex-post loan defaults, and as we will see in the last subsection of the results, as suggested also by lending to ex-ante riskier borrowers).

\section{B. Firm-level Credit Supply Outcomes and Real Effects}

To examine whether monetary policy shocks have real effects on firms, we need to analyze firm-period level data by matching the credit register to the firm balance sheet data. This allows us to investigate if for example the total credit that firms obtain is sensitive to changes in foreign monetary policies. Importantly, when we restricted the analysis in the loan level regressions to firms that borrowed from at least two banks in a period, the estimated coefficients of monetary policy remained relatively unchanged (see e.g. the comparison of columns 3 and 4 of Table 2, Panel A). Therefore, fixed effects at both firm and state*industry*period in firm-level data provide good enough controls for unobserved borrowers allowing us to identify the bank credit supply channel.

Moreover, as explained in the empirical strategy, we introduce an interaction of the one-year-lagged average monetary policy of a country with the one-year-lagged share of bank credit of a firm with banks from this country. A coefficient that is statistically different from zero implies that the monetary policy of a country has a stronger effect over firms with a higher ex-ante share of their credit from banks from this country, which may imply significant real effects. Conversely, a coefficient that is statistically zero implies that while at the loan level we find that (foreign) monetary policy matters, firms are able to smooth these foreign shocks by switching to other banks or to other forms of credit. An important assumption of this specification is that firm-bank relations are persistent, and that is precisely 
what we find in the data, with only 9 percent of firms switching their main bank from one year to the next. ${ }^{39}$

The first five columns of Table 3 present the results of our bank credit outcomes for the firm-year level data. We find that, on average, firms with a higher lagged share of bank credit from foreign banks are more affected by the monetary policy in these countries. ${ }^{40}$ For example, for firms that had their total bank credit with foreign banks in the previous year, a 1 standard deviation reduction in the intrate ${ }^{Y}-f g n$ in the current year leads to an increase in the loan volume of 1.5 percent, a rise in maturity and collateral of 4.9 percent and 4.8 percent respectively, and a decline of 0.8 percent in interest rate. In addition, regarding loan default (delinquencies), a 1 standard deviation reduction in the intrate ${ }^{Y}$-fgn increases loan default by 5.3 percent. Finally, the impact of the average non-standard monetary policy at the firm-level is in general not statistically significant, except for collateral and default, but the lack of significance is partly due to higher standard errors.

There are also significant real effects. On the extensive margin, a 1 standard deviation reduction in intrate ${ }^{Y}$-fgn reduces firm exit due to loan defaults by 1 percent. The final six columns display the results for the intensive margin for firm-level variables obtained from Orbis. For total liabilities, assets, fixed-assets and employment, we find that foreign monetary policy shocks have real impacts on firms (columns 7 to 12). For instance, total liabilities of firms (including bank credit) increase by 1.2 percent, when in a given year the average foreign monetary policy declines by 1 standard deviation, while fixed-assets (i.e., net investment) rise by 0.5 percent. $^{41}$ Employment also increases, but only by 0.3 percent.

\footnotetext{
${ }^{39}$ Regarding the switching determinants, we find that switching rates are positively related with firm size and with the number of bank relations of a firm, and negatively related with loan's duration and volume. Somewhat surprisingly, if we define small (large) firms as those with fewer (more) than 50 employees (as defined by Beck and Demirguc-Kunt (2006)) we find that the switching rates are somewhat similar at 8 and 11 percent respectively. See also Table A6.

${ }^{40}$ Even when the lagged variable is of one year in the firm level as opposed to one month in the loan level.

${ }^{41} \mathrm{We}$ analyze net, not gross, investment, which is common in the literature, see e.g. Lang, Ofek, and Stulz (1996). If investment expenditures just match the depreciation of capital equipment, then gross investment rises; however, net investment is unchanged. Higher net investment, not gross one, is what matters for overall productivity, where net investment is computed as the annual change in fixed tangible assets. Note also that the effects are larger for bank credit than total liabilities and assets (see Table A18 that results do not depend on the scale of the different firm variables).
} 
Furthermore, since with this data set we only have few yearly observations for each firm after the QE period started, our results for the impact of non-standard monetary policies on real outcomes could lack statistical power (e.g. for loan outcomes, all QE results are statistically significant in the monthly level data). ${ }^{42}$ Moreover, we analyze whether the impact of the monetary policy is different depending on firm size. To do that, we re-estimate equation (2) interacting the monetary policies with an indicator for small firms with fewer than 50 employees (following Beck and Demirguc-Kunt (2006)). Results are displayed in Table A19 in the Appendix, and indicate that the effects are indeed stronger for smaller firms, while inexistent for large firms. Therefore, and given the somewhat overrepresentation of large firms in Orbis (see Table A5), our results for the firm balance-sheet variables suggest a lower bound on the real effects.

A possible concern regarding the relatively subdued impact of QE on the majority of the results is that this non-conventional policy is highly correlated with periods of high risk and uncertainty, such as those lived after the global financial crisis. Therefore, it is possible that the results, especially on QE, may be biased towards zero given the positive correlation between the QE measures and various measures of financial risk. To test for this possibility, we interact our QE measure with sovereign CDS of that same country. Results are displayed in Table A14 in the Appendix. We find that indeed QE results are stronger, the lower the CDS of the sovereign where the foreign bank is headquartered in. This may explain why for some results, elasticities from QE are lower than interest rates ones, especially from the Eurozone banks given the Eurozone crisis. All in all, when the Federal Reserve, the ECB and the Bank of England expand their balance sheet via nonstandard monetary policies, the U.S. and European banks expand less into Mexico, the higher the risk in the countries where their parent countries are.

\section{Reach-for-yield and Risk-taking Channel of Monetary Policy}

To further understand the risk taking behavior of banks, and to know whether they engage in ex-ante reach-for-yield, we examine whether credit terms are more likely to change

\footnotetext{
${ }^{42}$ See Table A16 and A17 for different lags of monetary policy on firm outcomes.
} 
for firms with higher ex-ante loan interest rates, which tend to have higher ex-post default rates (see Table A3). To do this, in each period we calculate the average interest rate charged by banks to all firms (firm-bank observations weighted by loan volume). We then separate our sample into two groups depending on whether their ex-ante cost of credit is above or below this average cost. Finally, we run equation (1) separately for these two samples of firms. The results of this exercise are exhibited in Table 4.

Results indicate that on average, foreign banks soften more lending conditions to firms with higher ex-ante interest rate when foreign monetary policy is relaxed. These effects operate in the same direction for the different lending margins and imply higher future loan defaults. In the first two columns of Table 4, we find that a 1 standard deviation decrease in the foreign monetary policy expands loan volume for the high-yield group by an average of 5 percent, and only by 1.3 percent in the low-yield group. Effects are large for US, UK and Eurozone banks. Similarly, a 1 standard deviation increase in QE increases loan volume of the high-yield firms by around 1.5 percent but has no statistically significant effect on the sample of low yield firms. ${ }^{43}$

Loan maturity (proxying liquidity risk) is the credit margin by which high-yield firms (proxying credit risk) benefit relatively more with an expansion in monetary policies. As columns 3 and 4 indicate, a reduction of 1 standard deviation in the average foreign interest rate lengthens the average loan maturity by 10 percent for firms with high-yield, whereas its effect is negligible among low-yield firms. Furthermore, we also find that on average foreign QE has a stronger, albeit smaller, effect on low-yield firms. In addition, while banks extend on average larger and longer loans to riskier firms when foreign monetary policy expands, the value of collateral requirements is higher, possibly due to valuation effects (Columns 5 and 6). ${ }^{44}$ Regarding loan rates, columns 7-8 display our results. In general, loan interest rates from high-yield firms respond in the direction of the changes to foreign monetary policy,

\footnotetext{
${ }^{43}$ On QE, effects are not significant for Eurozone banks, except for higher ex-post loan defaults. Note these banks were more affected by higher CDSs of their sovereign, which we show that mitigate the impact of QE on loan margins.

${ }^{44}$ However, adjustments in collateral values vary substantially depending on the bank's nationality, but again, are in general higher for low-yield firms when foreign monetary policy is relaxed.
} 
whereas low-yield firms do not. On average, a 1 standard deviation reduction of foreign monetary policy translates into a 1.1 percent reduction of the average loan rate of high-yield firms. As with other credit margins, interest rates of loans are also influenced by movements in QE. Our results suggest that a 1 standard deviation increase in qe-us translates in a reduction of 0.3 percentage points on the average loan rate of loans for high-yield firms.

Focusing on future default, in columns 9 and 10, we also find that the impact of loosening of credit conditions on future default is concentrated among firms with high-yield. In particular, default rates are more responsive to movements in the monetary policy from the U.S. and the U.K. (both standard and non-standard) and from the Eurozone (mainly nonstandard). For instance, a reduction of 1 standard deviation in the foreign interest rate increases the average default for high-yield firms by 11.7 percent and has no significant impact for low-yield firms. Similarly, the expansion in QE also increases the incidence of default. Changes in foreign $\mathrm{QE}$ are associated on average with an 8.6 percent increase in the share of bank credit in default among high-yield firms.

All in all, the impact of low foreign monetary policy rates and expansive QE on higher credit supply is stronger on borrowers with higher ex-ante loan rates, proxying for reach-foryield, and with higher ex-post loan defaults, thus suggesting an international risk-taking channel of monetary policy.

\section{Conclusions}

In this paper, we analyze the international bank lending and risk-taking channel of monetary policy rates and QE through foreign banks, and their effects on the supply of credit to local firms, the associated real effects in the economy and reach-for-yield risk-taking incentives. We analyze foreign banks, as foreign banks, apart from being affected by their home monetary policy, are important around the world, and even more in emerging markets and developing countries where they have around 50 percent of the market share in terms of loans, deposits and profits (see Claessens and van Horen, 2012). Despite the importance of these questions for public policy (notably central banking policies and international monetary and financial coordination) and academia (international macro-finance), identification of the 
international channel of monetary policy has been elusive due to the lack of exploitation of comprehensive credit registry data matched with firm and bank information. As we stressed in the Introduction, the empirical literature on the international risk-taking and credit channel of monetary policy has worked on macro or bank level data. We overcome this hurdle by analyzing Mexico, an excellent empirical setting for identification given the exhaustive micro datasets (credit register matched to firm and bank level data) and also given the important presence of foreign banks.

We use the supervisory dataset that contains all business loans in Mexico, including loan rates which are absent in most credit registers around the world, while exploiting foreign monetary policy shocks, both (standard) interest rate and (non-standard) QE. Loan-level data is crucial to identify credit supply (and risk-taking), especially as foreign banks may lend to different type of firms, and matched firm-credit level data is needed to measure the associated real effects of the credit channel of monetary policy.

The robust results suggest that a softening of foreign monetary policy increases the supply of credit of foreign banks to Mexican firms. Each regional policy shock mainly affects supply via their respective foreign banks, i.e. U.S., U.K. and Eurozone monetary policy mainly affects credit supply to Mexican firms via U.S., U.K. and Eurozone banks in Mexico, respectively. All loan terms are affected, but effects are substantially weaker for loan rates. Moreover, the international monetary policy channel implies strong real effects, with substantial stronger elasticities from monetary rates than QE. Finally, low foreign monetary policy rates and an expansion in QE lead to higher credit supply by foreign banks for borrowers with higher ex-ante loan rates (reach-for-yield), with substantial higher ex-post loan defaults, thus suggesting an international risk-taking channel of monetary policy.

All in all, the results suggest spillovers of core-countries' monetary policies on emerging markets, both in the foreign monetary softening part (with not only higher credit risk taken by foreign banks, but also higher liquidity risk stemming from higher foreign funding) and in the tightening part (with the negative associated local real effects in terms of 
lower firm total assets, net investment, employment and survival). ${ }^{45}$ Importantly, foreign monetary policy is not only key to analyze the international channel and to obtain exogenous variation of monetary policy, as compared to local policy, but moreover it is not determined by the local economic conditions of emerging markets, so a change of foreign policy can be further destabilizing, especially given the foreign bank channel we show in this paper. Results are consistent, among others, with some claims by the Governor Rajan of the Reserve Bank of India (2014) and Jackson Hole's speech by Rey (2013) on the effects of core countries' monetary policies on emerging markets' economies, and thus suggest a potential need for a more coordinated global monetary policy, for example at the G-20 level with both high income and emerging countries, or the use of local prudential policies in emerging markets. Hence, an avenue for future research, apart from analyzing the external (international) versus internal (local) spillovers of monetary policy, is whether local macroprudential policies can reduce, or even neutralize, the foreign spillovers stemming on emerging markets from foreign monetary policy in core economic areas, or whether global coordination of monetary policies are the only solution.

\section{Acknowledgments}

We are grateful to Banco de México, in particular to Ana Aguilar and Adrián De la Garza, for their support to this project. We thank Gabriel Chodorow-Reich, Mark Gertler, Peter Karadi, Fabrizio Lopez-Gallo Dey, Soledad Martinez-Peria, Victoria Nuguer, Pascual O’Dogherty, Raghuram Rajan, Hélène Rey, John Rogers, Andrei Shleifer, Jeremy Stein, conference participants at the NBER Summer Institute in Finance-Macro and Monetary Economics, and the seminar participants at Bank of England, Banca d'Italia, Banco de México, Banco de Portugal, CREI, Istituto Einaudi, Oxford University, World Bank, Vanderbilt University and the Federal Reserve Board for helpful comments. We thank Carlos Zarazúa for outstanding research assistance. The views in this paper are solely the

\footnotetext{
${ }^{45}$ Note that at the bank level, we also find that when foreign monetary policy is softer, the foreign subsidiaries take on more liabilities, especially foreign and short-term, and have more loan defaults on the asset side and higher expansion of the balance sheet. Therefore, our results are consistent with banks taking on higher liquidity risk (partly from foreigners, which are more fragile) and higher credit risk, providing more credit, to riskier exante and ex-post borrowers, and despite the shorter foreign liabilities, these banks lend at longer maturities in their assets.
} 
responsibility of the authors and should not be interpreted as reflecting the views of the Board of Governors of the Federal Reserve System or of any other person associated with the Federal Reserve System, the World Bank, or Banco de México. Peydró acknowledges

financial support from project ECO2012-32434 of the Spanish Ministry of Economics and Competitiveness and the European Research Council Grant (project 648398).

\section{References}

Acharya, V. and P. Schnabl. (2010): "Do Global Banks Spread Global Imbalances? The Case of Asset-Backed Commercial Paper During the Financial Crisis of 2007-09." IMF Economic Review vol. 58 (1), 37-73.

Adrian, T., and H. S. Shin (2011): "Financial Intermediaries and Monetary Economics," in Handbook of Monetary Economics 3a, ed. by B. M. Friedman, and M. Woodford. New York NY: Elsevier, 601-650.

Allen, F., and D. Gale (2000): "Bubbles and Crises," Economic Journal, 110, 236255.

- (2004): "Asset Price Bubbles and Monetary Policy," in Global Governance and Financial Crises, ed. by M. Desai, and Y. Said. London: Routledge, 19-42.

— (2007): “Understanding Financial Crises," New York NY: Oxford University Press.

Allen, F., and K. Rogoff (2011): “Asset Prices, Financial Stability and Monetary Policy," in The Riksbank's Inquiry into the Risks in the Swedish Housing Market, ed. by P. Jansson, and M. Persson. Stockholm: Sveriges Riksbank, 189-218.

Allen, F., E. Carletti, and D. Gale (2009): "Interbank Market Liquidity and Central Bank Intervention,” Journal of Monetary Economics, 56(5), 639-652.

- (2014): "Money, Financial Stability and Efficiency," Journal of Economic Theory, 149, 100-127. 
Altonji, J. G., T. E. Elder and C. R. Taber, (2005): "Selection on Observed and Unobserved Variables: Assessing the Effectiveness of Catholic Schools," Journal of Political Economy, 113(1), 151-184.

Altunbas, Y., Gambacorta, L., and D. Marques. (2014): “Does monetary policy affect bank risk?” International Journal of Central Banking 10(1): 95-135.

Arellano, M. (1987): "Computing Robust Standard Errors for Within-Group Estimators," Oxford Bulletin of Economics and Statistics, 49, 431-434.

Banco de Mexico (2014): "Reporte Sobre el Sistema Financiero".

Beck, Thorsten, and Asli Demirguc-Kunt. "Small and medium-size enterprises: Access to finance as a growth constraint." Journal of Banking \& Finance 30.11 (2006): 29312943.

Bernanke, B., (1983): "Nonmonetary Effects of the Financial Crisis in Propagation of the Great Depression," American Economic Review 73(3): 257-76.

Bernanke, B. and M. Gertler (1995): "Inside the Black Box: The Credit Channel of Monetary Policy Transmission," Journal of Economic Perspectives, 9(4), 27-48.

Bernanke, B. and A. Blinder (1992): “The Federal Funds Rate and the Channels of Monetary Transmission,” American Economic Review, 82, 901-921.

Bernanke, B. and C. Lown (1991): "The Credit Crunch," Brookings Papers on Economic Activity, 22, 205-248.

Borio, C., and H. Zhu (2008): “Capital Regulation, Risk-Taking and Monetary Policy: A Missing Link in the Transmission Mechanism," Working Paper, Bank for International Settlements.

Bruno, V. and Shin, H. (2015a): "Cross-Border Banking and Global Liquidity", Review of Economic Studies, 82 (2), 535-564.

(2015b): "Capital Flows and the Risk-Taking Channel of Monetary Policy" Journal of Monetary Economics, 71, 119-132. 
Calvo, G. and C. Reinhart (2000): "When Capital Inflows Come to a Sudden Stop: Consequences and Policy Options". In Kenen, P.; Swoboda, A. Reforming the International Monetary and Financial System. Washington, DC: International Monetary Fund.

Carabarin, M., A de la Garza, O. Moreno (2016): "Global Liquidity and Corporate Financing in Mexico", mimeo.

Cetorelli, N. and L. Goldberg (2012a): "Liquidity management of U.S. Global Banks: Internal Capital Markets in the Great Recession", Journal of International Economics, 88, 299-311.

(2012b): "Banking Globalization and Monetary Transmission," Journal of Finance, 67(5), 1811-43.

Claessens, S. and N. Van Horen (2012), "Foreign Banks: Trends, Impact and Financial Stability", International Monetary Fund Working Paper 12/10.

De Haas, R., N. Van Horen, (2012): "International Shock Transmission after the Lehman Brothers Collapse: Evidence from Syndicated Lending." American Economic Review: Papers \& Proceedings, 102(3): 231-237.

(2013): "Running for the Exit? International Bank Lending During a Financial Crisis." Review of Financial Studies 26: 244-285.

Dell'Ariccia, G, L Laeven and G Suarez (2015): "Bank leverage and monetary policy's risk-taking channel: Evidence from the United States", Journal of Finance, forthcoming.

Diamond, D. and R. Rajan (2006): "Money in a Theory of Banking," American Economic Review, 96(1), 30-53.

Diamond, D. and R. Rajan (2012): "Illiquid Banks, Financial Stability, and Interest Rate Policy," Journal of Political Economy, 120(3), 552-591. 
European Central Bank (2009): "Recent Developments in the Balance Sheets of the Eurosystem, the Federal Reserve System and the Bank of Japan," ECB Monthly Bulletin, October, 81-94.

_ (2011): “The Monetary Policy of the ECB," Third edition, May.

Freixas, X. and J. Jorge (2008): “The Role of Interbank Markets in Monetary Policy: A Model with Rationing,” Journal of Money, Credit and Banking, 40(6), 1151-1176.

Freixas, X., A. Martin, and D. Skeie, (2011): "Bank Liquidity, Interbank Markets, and Monetary Policy," The Review of Financial Studies, 24(8), 2656-2692.

Fischer, Stanley (2014): "The Federal Reserve and the Global Economy," Speech by Vice Chairman of the Board of Governors of the Federal Reserve System delivered as the Per Jacobsson Foundation Lecture. Annual Meetings of the International Monetary Fund and the World Bank Group Washington.

Gertler, M. and N. Kiyotaki (2010): "Financial Intermediation and Credit Policy in Business Cycle Analysis" In B. M. Friedman and M. Woodford (Eds.), Volume 3 of Handbook of Monetary Economics, Chapter 11, 547-599.

Gertler, M., and P. Karadi. (2011): “A Model of Unconventional Monetary Policy,” Journal of Monetary Economics 58 (1), 17-34.

Gertler, M., and P. Karadi. (2015): “Monetary Policy Surprises, Credit Costs, and Economic Activity,” American Economic Journal: Macroeconomics, 7(1): 44-76.

Giannetti, M. and L. Laeven. (2012): "The Flight Home Effect: Evidence from the Syndicated Loan Market during Financial Crises," Journal of Financial Economics 104(1): $23-43$.

Gourinchas, P.-O. \& M. Obstfeld, (2012): "Stories of the Twentieth Century for the Twenty-First," American Economic Journal: Macroeconomics, 4(1), 226-65.

Holmstrom, B. and J. Tirole (1998): "Private and Public Supply of Liquidity," Journal of Political Economy, 106(1), 1-40. 
IMF (2012): "Mexico: Financial Stability Assessment," IMF Country Report No. $12 / 65$.

INEGI (2014): "Exportaciones por Entidad Federativa”.

Ioannidou, V. P., S. Ongena, and J.-L. Peydró (2015): “Monetary Policy, RiskTaking and Pricing: Evidence from a Quasi-Natural Experiment," Review of Finance 19(1), $95-144$.

Jeon, B. N., Olivero, M. P., Wu, J. (2013): "Multinational banking and the international transmission of financial shocks: Evidence from foreign bank subsidiaries." Journal of Banking and Finance 37: 952-972.

Jiménez, G., S. Ongena, J.-L. Peydró, and J. Saurina (2012): “Credit Supply and Monetary Policy: Identifying the Bank Balance-Sheet Channel with Loan Applications" American Economic Review, 102(5), 2301-26.

(2014): "Hazardous Times for Monetary Policy: What do Twenty-Three Million Bank Loans Say about the Effects of Monetary Policy on Credit Risk-Taking?" Econometrica, 82(2), 463-505.

Jordà, Ò. and M. Schularick \& A. Taylor, (2011): "Financial Crises, Credit Booms, and External Imbalances: 140 Years of Lessons," IMF Economic Review, Palgrave Macmillan, 59(2), 340-378.

Kalemli-Ozcan, S., E. Papaioannou, and J.-L. Peydró (2013): "Financial Regulation, Financial Globalization, and the Synchronization of Economic Activity," Journal of Finance, $68,1179-1228$.

Kashyap, A. K., and J. Stein (2000): "What Do a Million Observations on Banks Say About the Transmission of Monetary Policy?" American Economic Review, 90, 407-428.

Khwaja, A. I. and A. Mian (2008): "Tracing the Impact of Bank Liquidity Shocks: Evidence from an Emerging Market," American Economic Review, 98(4), 1413-42. 
Kiyotaki, N. and J. Moore (2012): "Liquidity, Business Cycles, and Monetary Policy," NBER Working Papers 17934, National Bureau of Economic Research.

Lang, L., E. Ofek, and R. Stulz (1996): "Leverage, Investment and Firm Growth," Journal of Financial Economics, 40, 3-29.

Maddaloni, A., and J.-L. Peydró (2011): "Bank Risk-Taking, Securitization, Supervision, and Low Interest Rates: Evidence from Euro-Area and U.S. Lending Standards," Review of Financial Studies, 24, 2121-2165.

Mian, A. (2006): "Distance Constraints: The Limits of Foreign Lending in Poor Economies" Journal of Finance, 61(6), 1465-1505.

Mian, A., and A. Sufi. (2014): "What Explains the 2007-2009 Drop in Employment" Econometrica, 82, 2197-2223.

Miranda-Agrippino, S., Rey, H. (2015): "World Asset Markets and the Global Financial Cycle” Mimeo.

Nuguer, V., and G. Cuadra (2016): "Risky Banks and Macroprudential Policy for Emerging Economies", Working Papers 2016-06, Banco de México.

Ongena S. and D. Smith, (2001): “The Duration of Bank Relationships”, Journal of Financial Economics, 61, 449-475.

Paligorova, T., and J. Santos (2014): "Monetary Policy and Bank Risk- Taking: Evidence from the Corporate Loan Market," Journal of Financial Intermediation, forthcoming.

Peek, J., and E. S. Rosengren (2000): “Collateral Damage: Effects of the Japanese Bank Crisis on Real Activity in the United States," American Economic Review 90, 30-45.

Popov, A., G. Udell, (2012): “Cross-border banking, credit access, and the financial crisis." Journal of International Economics 87: 147-161. 
Rajan, R. (2005): "Has Finance Made the World Riskier?" speech presented at Jackson Hole, Federal Reserve Bank, Federal Reserve Bank, August.

_ (2014): “Competitive Monetary Easing: Is It Yesterday Once More?” Speech at the Brookings Institution.

Reinhart, C., and K. Rogoff (2009): "This Time is Different: Eight Centuries of Financial Folly", Princeton University Press.

Rey, H. (2013): "Dilemma Not Trilemma: The Global Financial Cycle and Monetary Policy Independence," paper presented at "Global Dimensions of Unconventional Monetary Policy," Jackson Hole, Federal Reserve Bank, August 22-24.

Schnabl, P. (2012): “The International Transmission of Bank Liquidity Shocks: Evidence from an Emerging Market," Journal of Finance, 67:897-932.

Schularick, M., and A. M. Taylor (2012): “Credit Booms Gone Bust: Monetary Policy, Leverage Cycles, and Financial Crises, 1870-2008," American Economic Review, 102, 1029-61.

Shleifer, A., and R. Vishny, (2010): "Unstable Banking," Journal of Financial Economics 97(3): 306-318.

Stein, J. (1998): “An Adverse-Selection Model of Bank Asset and Liability Management with Implications for the Transmission of Monetary Policy.” RAND Journal of Economics 29 (3): 466-486.

(2012): “Monetary Policy as Financial-Stability Regulation.” Quarterly Journal of Economics 127 (1): 57-95.

(2013): "Overheating in Credit Markets: Origins, Measurement, and Policy Responses," Speech by Federal Reserve Board Governor Jeremy Stein, February 7, 2013.

Stiglitz, J. and A. Weiss, (1981): "Credit Rationing in Markets with Imperfect Information." American Economic Review, 71, Issue 3, p. 393-410. 
Table 1. Summary Statistics

\begin{tabular}{|c|c|c|c|}
\hline Variable & Mean & Median & St. Dev \\
\hline \multicolumn{4}{|l|}{ Variables at the Loan-Month Level } \\
\hline loan volume (thousands of Mexican pesos) & 2,244 & 379 & 6,168 \\
\hline loan maturity (months) & 33.2 & 36.0 & 21.1 \\
\hline loan collateral & 0.26 & 0.00 & 0.52 \\
\hline loan rate & 0.15 & 0.15 & 0.07 \\
\hline loan default & 0.07 & 0.00 & 0.26 \\
\hline intrate-us & 0.015 & 0.002 & 0.019 \\
\hline intrate-uk & 0.024 & 0.005 & 0.022 \\
\hline intrate-euro & 0.017 & 0.010 & 0.015 \\
\hline intrate-mex & 0.058 & 0.046 & 0.018 \\
\hline intrate-usr & -0.002 & -0.007 & 0.017 \\
\hline intrate-ukr & 0.000 & -0.002 & 0.020 \\
\hline intrate-euror & 0.000 & -0.003 & 0.012 \\
\hline intrate-fgnr & 0.000 & 0.000 & 0.014 \\
\hline intrate-mexr & 0.000 & -0.001 & 0.010 \\
\hline qe-us & 0.022 & 0.013 & 0.027 \\
\hline qe-uk & 0.018 & 0.004 & 0.030 \\
\hline qe-euro & 0.015 & 0.013 & 0.032 \\
\hline qe-fgn & 0.002 & 0.000 & 0.028 \\
\hline bank-us & 0.152 & 0.000 & 0.359 \\
\hline bank-uk & 0.134 & 0.000 & 0.341 \\
\hline bank-euro & 0.323 & 0.000 & 0.468 \\
\hline bank-mex & 0.386 & 0.000 & 0.487 \\
\hline \multicolumn{4}{|l|}{ Variables at the Firm-Year Level } \\
\hline $\begin{array}{l}\text { loan volume }{ }^{\mathrm{Y}} \text { (thousands of Mexican } \\
\text { pesos) }\end{array}$ & 25,795 & 3,304 & 86,906 \\
\hline loan maturity ${ }^{\mathrm{Y}}$ (months) & 33.1 & 34.3 & 22.8 \\
\hline loan collateral ${ }^{\mathrm{Y}}$ & 0.27 & 0.00 & 0.57 \\
\hline loan $\operatorname{rate}^{\mathrm{Y}}$ & 0.15 & 0.15 & 0.08 \\
\hline loan default ${ }^{\mathrm{Y}}$ & 0.06 & 0.00 & 0.24 \\
\hline $\operatorname{exit}^{Y}$ & 0.04 & 0.00 & 0.19 \\
\hline intrate ${ }^{\mathrm{Y}}$-fgnr*share ${ }^{\mathrm{Y}}$-fgn & 0.000 & 0.000 & 0.010 \\
\hline intrate $^{Y}$-mexr* share $^{Y}$-mex & 0.000 & 0.000 & 0.004 \\
\hline $\mathrm{qe}^{\mathrm{Y}}-\mathrm{fgn}^{*}$ share $^{\mathrm{Y}}$-fgn & 0.001 & 0.000 & 0.022 \\
\hline
\end{tabular}




\begin{tabular}{lccc} 
Variable & Mean & Median & St. Dev \\
\hline Variables at the Firm-Year Level (Orbis sample) & & \\
assets $^{Y}$ & 308,128 & 19,850 & $1,105,935$ \\
fixed assets $^{Y}$ & 95,202 & 3,042 & 354,762 \\
liabilities $^{Y}$ & 110,190 & 9,350 & 362,078 \\
non-current liabilities $^{\mathrm{Y}}$ & 22,949 & 0 & 94,264 \\
current liabilities $^{\mathrm{Y}}$ & 82,555 & 8,180 & 216,639 \\
employment $^{\mathrm{Y}}$ (units) & 115 & 40 & 177 \\
\hline
\end{tabular}

Notes: Table A1 presents the definitions of all variables. Loan-level data at the loan-month and firmyear levels consist of 8,268,794 and 747,910 observations, respectively, and 14,563 firm-year observations from Orbis (see Table 2 and 3 and the data section of the paper for more detailed information); all variables from the Orbis sample are in thousands of Mexican pesos, with the exception of employment ${ }^{Y}$. 
Table 2- Panel A. Impact of International Monetary Policies on Domestic Loan Volume

\begin{tabular}{|c|c|c|c|c|}
\hline & (1) & $(2)$ & (3) & (4) \\
\hline intrate-usr & $\begin{array}{l}-0.19 \\
(0.16)\end{array}$ & & & \\
\hline intrate-usr $*$ bank-us & $\begin{array}{c}-2.93 * * * \\
(0.34)\end{array}$ & $\begin{array}{c}-3.55 * * * \\
(0.40)\end{array}$ & $\begin{array}{c}-3.21 * * * \\
(0.35)\end{array}$ & $\begin{array}{c}-3.31 * * * \\
(0.54)\end{array}$ \\
\hline intrate-ukr & $\begin{array}{l}-0.11 \\
(0.30)\end{array}$ & & & \\
\hline intrate-ukr * bank-uk & $\begin{array}{c}-1.05 * * \\
(0.49)\end{array}$ & $\begin{array}{c}-2.42 * * * \\
(0.54)\end{array}$ & $\begin{array}{l}-2.11 * * * \\
(0.46)\end{array}$ & $\begin{array}{l}-2.45 * * * \\
(0.74)\end{array}$ \\
\hline intrate-euror & $\begin{array}{c}2.05^{* * * *} \\
(0.63)\end{array}$ & & & \\
\hline intrate-euror * bank-euro & $\begin{array}{c}-2.10 * * \\
(0.82)\end{array}$ & $\begin{array}{l}-1.70^{*} \\
(0.97)\end{array}$ & $\begin{array}{c}-1.12 * * \\
(0.54)\end{array}$ & $\begin{array}{l}-0.63 \\
(0.82)\end{array}$ \\
\hline intrate-mexr & $\begin{array}{c}-0.59 * * * \\
(0.19)\end{array}$ & & & \\
\hline intrate-mexr $*$ bank-mex & $\begin{array}{l}-0.03 \\
(0.32)\end{array}$ & $\begin{array}{c}0.58 \\
(0.47)\end{array}$ & $\begin{array}{l}-0.03 \\
(0.47)\end{array}$ & $\begin{array}{l}-0.10 \\
(0.75)\end{array}$ \\
\hline qe-us & $\begin{array}{c}-0.52 * * * \\
(0.10)\end{array}$ & & & \\
\hline qe-us $*$ bank-us & $\begin{array}{c}0.56^{* *} \\
(0.26)\end{array}$ & $\begin{array}{l}0.95^{* * *} \\
(0.26)\end{array}$ & $\begin{array}{l}0.85^{* * *} \\
(0.20)\end{array}$ & $\begin{array}{l}0.90 * * * \\
(0.28)\end{array}$ \\
\hline qe-uk & $\begin{array}{l}-0.04 \\
(0.11)\end{array}$ & & & \\
\hline qe-uk $*$ bank-uk & $\begin{array}{c}0.65^{* * * *} \\
(0.19)\end{array}$ & $\begin{array}{l}0.70 * * \\
(0.34)\end{array}$ & $\begin{array}{l}0.58^{*} \\
(0.32)\end{array}$ & $\begin{array}{c}0.55 \\
(0.48)\end{array}$ \\
\hline qe-euro & $\begin{array}{l}0.13^{*} \\
(0.07)\end{array}$ & & & \\
\hline qe-euro * bank-euro & $\begin{array}{c}0.37 * * * \\
(0.12)\end{array}$ & $\begin{array}{c}0.07 \\
(0.14)\end{array}$ & $\begin{array}{c}0.10 \\
(0.10)\end{array}$ & $\begin{array}{c}0.06 \\
(0.16)\end{array}$ \\
\hline Firm*Bank F.E. & Yes & Yes & Yes & Yes \\
\hline State*Industry*Period F.E. & No & Yes & Yes & - \\
\hline Firm*Period F.E. & No & No & No & Yes \\
\hline $\begin{array}{l}\text { Firms borrowing from more than } 1 \\
\text { bank }\end{array}$ & No & No & Yes & Yes \\
\hline Observations & $8,268,794$ & $8,268,794$ & $3,020,617$ & $3,020,617$ \\
\hline R-squared & 0.01 & 0.03 & 0.04 & 0.47 \\
\hline \multicolumn{5}{|c|}{$\begin{array}{l}\text { Notes: Estimates from OLS regressions. Observations are at the firm-bank-month level. The dependen } \\
\text { variable is the volume of loans, in logs, from a firm with a bank in a given month. intrate-countryr is the } \\
\text { residual of policy rate of country, where country stands for US, UK, Euro Area or Mexico. qe-country is the } \\
\text { ratio of the yearly real change in central bank assets to GDP of country. bank- country is an indicator that } \\
\text { bank headquarters are in country. Other controls are listed in section } 2 \text { of the paper. Fixed effects already } \\
\text { absorbed by other fixed effects are indicated by "_.". Standard errors are reported in parentheses and are } \\
\text { clustered at the period and bank-industry level, where period is month. *significant at } 10 \text { percent } \\
* * \text { significant at } 5 \text { percent, ***significant at } 1 \text { percent. }\end{array}$} \\
\hline
\end{tabular}


Table 2- Panel B. Impact of International Monetary Policies on Other Domestic Credit Margins

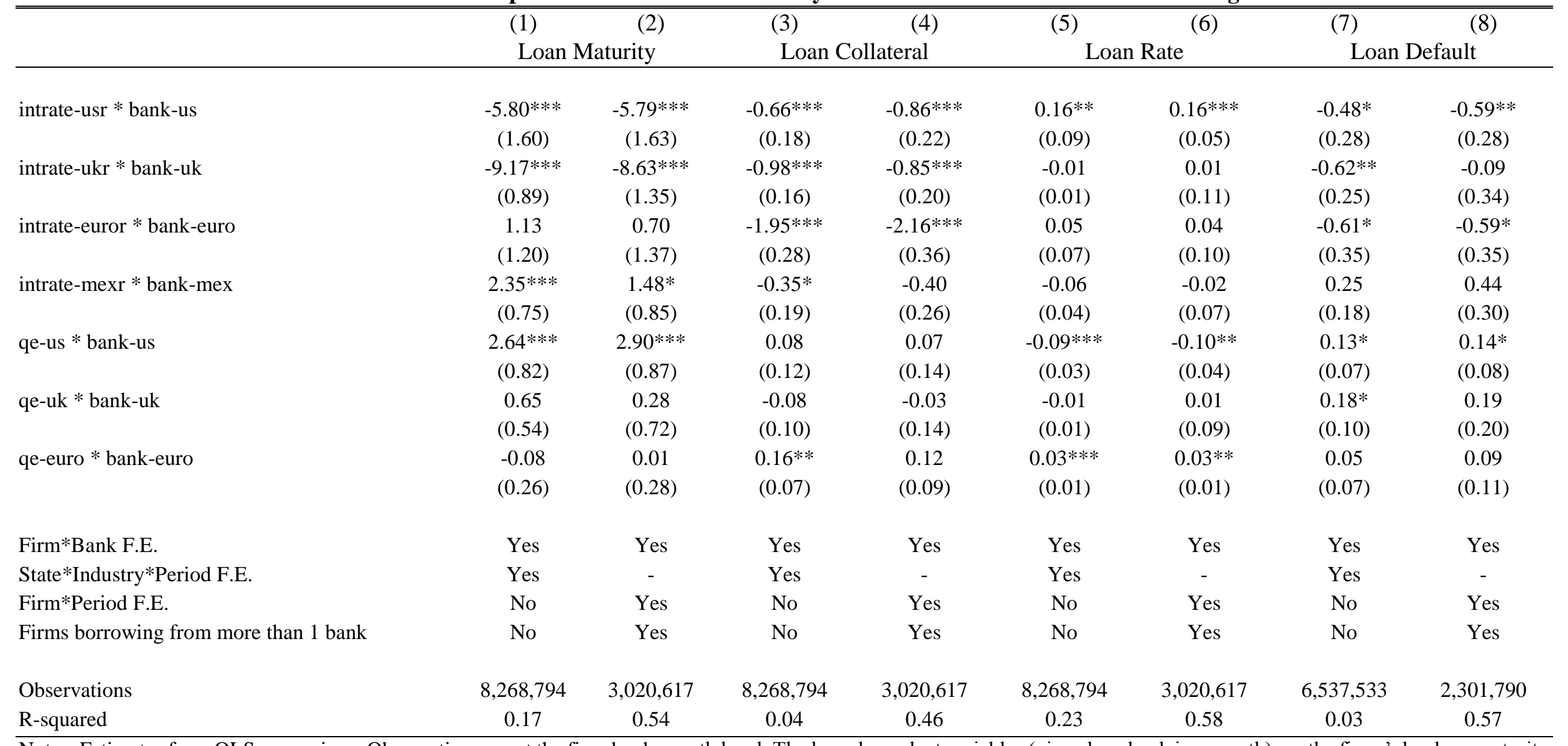

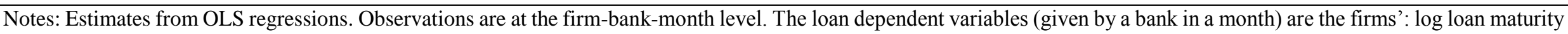

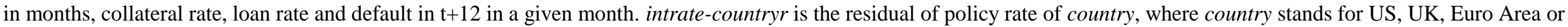

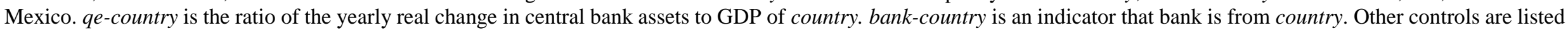

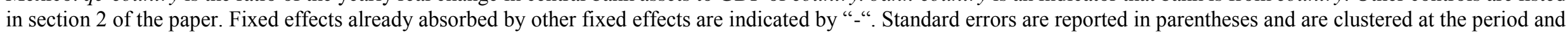
bank-industry level, where period is month. *significant at 10 percent, **significant at 5 percent, ***significant at 1 percent. 
Table 2- Panel C. Impact of 3-month to 12-month lagged International Monetary Policies on Domestic Credit Margins

\begin{tabular}{|c|c|c|c|c|c|c|c|c|c|c|c|c|c|c|c|}
\hline & (1) & (2) & (3) & (4) & (5) & (6) & (7) & (8) & (9) & (10) & (11) & (12) & (13) & (14) & (15) \\
\hline & \multicolumn{3}{|c|}{ Loan Volume } & \multicolumn{3}{|c|}{ Loan Maturity } & \multicolumn{3}{|c|}{ Loan Collateral } & \multicolumn{3}{|c|}{ Loan Rate } & \multicolumn{3}{|c|}{ Loan Default } \\
\hline & $3 \mathrm{~m} \mathrm{lag}$ & $6 \mathrm{~m} \mathrm{lag}$ & $12 \mathrm{~m} \mathrm{lag}$ & $3 \mathrm{~m} \mathrm{lag}$ & $6 \mathrm{~m} \mathrm{lag}$ & $12 \mathrm{~m} \mathrm{lag}$ & $3 \mathrm{~m} \mathrm{lag}$ & $6 \mathrm{~m} \mathrm{lag}$ & $12 \mathrm{~m} \mathrm{lag}$ & $3 \mathrm{~m}$ lag & $6 \mathrm{~m} \mathrm{lag}$ & $12 \mathrm{~m} \mathrm{lag}$ & $3 \mathrm{~m} \mathrm{lag}$ & $6 \mathrm{~m} \mathrm{lag}$ & $12 \mathrm{~m} \mathrm{lag}$ \\
\hline intrate-fgnr & $-1.46^{* *}$ & $-1.81 * * *$ & $-2.05 * * *$ & $-4.81 * * *$ & $-4.72 * * *$ & $-4.29 * * *$ & $-1.09 * * *$ & $-1.25 * * *$ & $-1.34 * * *$ & 0.04 & $0.07 *$ & $0.20^{* * *}$ & $-0.49 * * *$ & $-0.49 * * *$ & $-0.26^{*}$ \\
\hline *bank-fgn & $(0.58)$ & $(0.57)$ & $(0.46)$ & $(1.16)$ & $(1.21)$ & $(1.13)$ & $(0.33)$ & $(0.32)$ & $(0.28)$ & $(0.04)$ & $(0.04)$ & $(0.02)$ & $(0.14)$ & $(0.13)$ & $(0.13)$ \\
\hline intrate- & 0.06 & 0.50 & 0.25 & $2.50 * * *$ & $2.94 * * *$ & $3.41 * * *$ & $-0.79 * * *$ & -0.34 & $0.71 * * *$ & 0.04 & $0.10 * *$ & $0.06 * *$ & 0.28 & 0.2 & 0.18 \\
\hline *bank-mex & $(0.34)$ & $(0.40)$ & $(0.28)$ & $(0.84)$ & $(0.82)$ & $(0.89)$ & $(0.26)$ & $(0.25)$ & $(0.20)$ & $(0.04)$ & $(0.04)$ & $(0.02)$ & $(0.21)$ & $(0.17)$ & $(0.17)$ \\
\hline qe-fgn & $0.31 * *$ & $0.46^{* * *}$ & $0.50^{* * * *}$ & $1.00^{* * *}$ & $1.35^{* * * *}$ & $1.34 * * *$ & $0.17 * * *$ & $0.13 * *$ & 0.08 & 0.01 & 0.01 & 0.01 & 0.03 & 0.05 & $0.21 * * *$ \\
\hline *bank-fgn & $(0.11)$ & $(0.09)$ & $(0.09)$ & $(0.24)$ & $(0.23)$ & $(0.25)$ & $(0.06)$ & $(0.05)$ & $(0.06)$ & $(0.01)$ & $(0.01)$ & $(0.01)$ & $(0.05)$ & $(0.05)$ & $(0.04)$ \\
\hline F*B F.E. & Yes & Yes & Yes & Yes & Yes & Yes & Yes & Yes & Yes & Yes & Yes & Yes & Yes & Yes & Yes \\
\hline S*I*P F.E. & Yes & Yes & Yes & Yes & Yes & Yes & Yes & Yes & Yes & Yes & Yes & Yes & Yes & Yes & Yes \\
\hline Obs. & $7,046,918$ & $7,046,918$ & $7,046,918$ & $7,046,918$ & $7,046,918$ & $7,046,918$ & $7,046,918$ & $7,046,918$ & $7,046,918$ & $7,046,918$ & $7,046,918$ & $7,046,918$ & $5,196,351$ & $5,196,351$ & $5,196,351$ \\
\hline R-squared & 0.03 & 0.03 & 0.03 & 0.13 & 0.13 & 0.13 & 0.04 & 0.04 & 0.04 & 0.18 & 0.18 & 0.19 & 0.03 & 0.03 & 0.03 \\
\hline
\end{tabular}

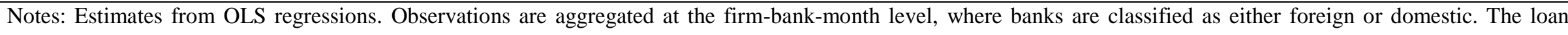

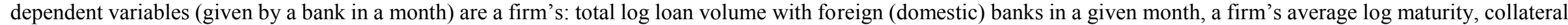

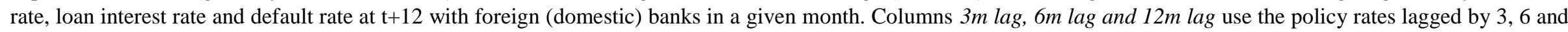

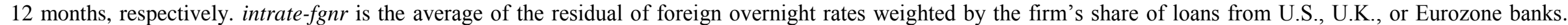

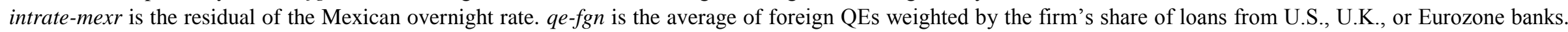

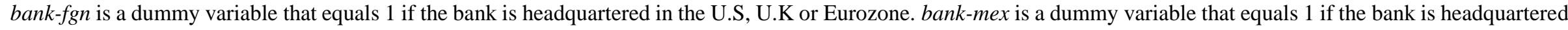

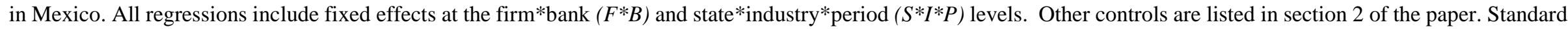

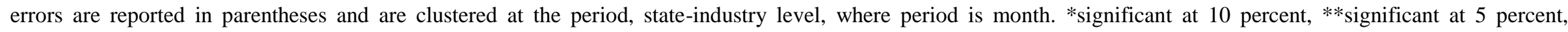
$* * *$ significant at 1 percent. 
Table 3. Impact of International Monetary Policy on Domestic Firm-Level Real Effects and Credit Outcomes

\begin{tabular}{|c|c|c|c|c|c|c|c|c|c|c|c|c|}
\hline & $\begin{array}{c}(1) \\
\text { Credit } \\
\text { Volume }\end{array}$ & $\begin{array}{c}(2) \\
\text { Credit } \\
\text { Maturity }\end{array}$ & $\begin{array}{c}(3) \\
\text { Credit } \\
\text { Collateral }\end{array}$ & $\begin{array}{l}(4) \\
\text { Credit } \\
\text { Rate }\end{array}$ & $\begin{array}{c}(5) \\
\text { Credit } \\
\text { Default }\end{array}$ & $\begin{array}{l}(6) \\
\text { Exit }\end{array}$ & $\begin{array}{c}(7) \\
\text { Liabilities }\end{array}$ & $\begin{array}{c}(8) \\
\text { Current } \\
\text { Liabilities }\end{array}$ & $\begin{array}{c}(9) \\
\text { Non- } \\
\text { Current } \\
\text { Liabilities }\end{array}$ & $\begin{array}{c}(10) \\
\text { Assets }\end{array}$ & $\begin{array}{l}(11) \\
\text { Fixed } \\
\text { Assets }\end{array}$ & $\begin{array}{c}\text { (12) } \\
\text { Employment }\end{array}$ \\
\hline intrate $^{\mathrm{Y}}$-fgnr* share $^{\mathrm{Y}}$-fgn & $\begin{array}{l}-1.54 * \\
(0.89)\end{array}$ & $\begin{array}{c}-4.92 * * \\
(1.88)\end{array}$ & $\begin{array}{c}-1.32 * * \\
(0.52)\end{array}$ & $\begin{array}{l}0.12 * \\
(0.07)\end{array}$ & $\begin{array}{l}-0.32 * \\
(0.19)\end{array}$ & $\begin{array}{l}0.92 * \\
(0.54)\end{array}$ & $\begin{array}{c}-1.20 * * \\
(0.40)\end{array}$ & $\begin{array}{c}-1.26 * * * \\
(0.38)\end{array}$ & $\begin{array}{c}-2.08 * * \\
(0.65)\end{array}$ & $\begin{array}{l}-0.76^{*} \\
(0.39)\end{array}$ & $\begin{array}{l}-0.45^{*} \\
(0.25)\end{array}$ & $\begin{array}{l}-0.34 * \\
(0.20)\end{array}$ \\
\hline intrate $^{\mathrm{Y}}$-mexr* share $^{\mathrm{Y}}$-mex & $\begin{array}{l}3.28 * \\
(1.83)\end{array}$ & $\begin{array}{c}4.37 \\
(3.85)\end{array}$ & $\begin{array}{c}0.16 \\
(2.23)\end{array}$ & $\begin{array}{l}-0.02 \\
(0.10)\end{array}$ & $\begin{array}{c}0.05 \\
(0.68)\end{array}$ & $\begin{array}{l}-0.22 \\
(0.70)\end{array}$ & $\begin{array}{c}0.43 \\
(0.69)\end{array}$ & $\begin{array}{c}0.93 \\
(0.61)\end{array}$ & $\begin{array}{l}-1.23 \\
(2.88)\end{array}$ & $\begin{array}{l}0.85 * * \\
(0.31)\end{array}$ & $\begin{array}{c}1.19 * * * \\
(0.15)\end{array}$ & $\begin{array}{c}0.27 \\
(0.57)\end{array}$ \\
\hline $\mathrm{qe}^{\mathrm{Y}}-$ fgn $^{*} \operatorname{share}^{\mathrm{Y}}$-fgn & $\begin{array}{c}0.24 \\
(0.31)\end{array}$ & $\begin{array}{c}0.95 \\
(0.96)\end{array}$ & $\begin{array}{l}0.39 * * \\
(0.18)\end{array}$ & $\begin{array}{c}0.03 \\
(0.04)\end{array}$ & $\begin{array}{l}0.14 * \\
(0.08)\end{array}$ & $\begin{array}{c}0.02 \\
(0.10)\end{array}$ & $\begin{array}{c}0.20 \\
(0.16)\end{array}$ & $\begin{array}{c}0.09 \\
(0.20)\end{array}$ & $\begin{array}{c}0.43 \\
(0.40)\end{array}$ & $\begin{array}{c}0.15 \\
(0.15)\end{array}$ & $\begin{array}{c}0.68 * * * \\
(0.12)\end{array}$ & $\begin{array}{l}-0.06 \\
(0.12)\end{array}$ \\
\hline $\begin{array}{l}\text { Firm F.E. } \\
\text { State*Industry*Year } \\
\text { F.E. }\end{array}$ & Yes & Yes & Yes & Yes & Yes & Yes & Yes & Yes & Yes & Yes & Yes & Yes \\
\hline Observations & 747,910 & 747,910 & 747,910 & 747,910 & 735,240 & 747,913 & 13,918 & 13,918 & 13,918 & 14,563 & 14,563 & 13,838 \\
\hline R-squared & 0.09 & 0.14 & 0.04 & 0.17 & 0.03 & 0.04 & 0.20 & 0.20 & 0.25 & 0.26 & 0.22 & 0.19 \\
\hline
\end{tabular}

Notes: Estimates from OLS regressions. Observations are aggregated at the firm-year level. The first six columns use the information from the loan-level dataset and refer to a firm's: loan volume in logs, maturity in logs, collateral rate, loan interest rate, 1-year-ahead default rate and a proxy of firm survival. The last six columns restrict the sample to firms that are observed in the loan-level dataset and in the Orbis dataset. The dependent variables are a firm's log liabilities (total, current, noncurrent), log assets (total and fixed) and employment in a given year. intrate ${ }^{Y}$-fgnr is the yearly average of the residual of foreign overnight rates weighted by the firm's share of loans from U.S., U.K., or Eurozone banks. share ${ }^{Y}$-fgn is the one-year-lagged share of a firm's debt with foreign banks. intrate ${ }^{Y}$-mexr is the residual of the Mexican overnight rate. share ${ }^{Y}$ - mex is a firm's one-year-lagged-share of loans from Mexican banks. $q e^{Y}$-fgn is the average of foreign QE weighted by the firm's share of loans from U.S., U.K., or Eurozone banks. share ${ }^{Y}$-fgn is the one-year-lagged share of a firm's bank debt from foreign banks. All regressions include fixed effects at the firm and state*industry*year level. Standard errors are reported in parentheses and are clustered at the state*year level. *significant at 10 percent, $* *$ significant at 5 percent, $* * *$ significant at 1 percent. 
Table 4. Impact of International Monetary Policies on Domestic Credit Margins by Ex-Ante Loan Rates

\begin{tabular}{|c|c|c|c|c|c|c|c|c|c|c|}
\hline & (1) & $(2)$ & (3) & (4) & $(5)$ & (6) & $(7)$ & (8) & $(9)$ & (10) \\
\hline & \multicolumn{2}{|c|}{ Loan Volume } & \multicolumn{2}{|c|}{ Loan Maturity } & \multicolumn{2}{|c|}{ Loan Collateral } & \multicolumn{2}{|c|}{ Loan Rate } & \multicolumn{2}{|c|}{ Loan Default } \\
\hline & High yield & Low yield & High yield & Low yield & High yield & Low yield & High yield & Low yield & High yield & Low yield \\
\hline \multirow[t]{2}{*}{ intrate-usr* bank-us } & $-3.92 * * *$ & $-2.28 * * *$ & $-6.46 * * *$ & $-0.89 * *$ & $-0.59 * * *$ & $-1.40 * * *$ & $0.20 * * *$ & 0.02 & $-0.59 *$ & $0.58 * *$ \\
\hline & $(0.43)$ & $(0.69)$ & $(1.78)$ & $(0.45)$ & $(0.15)$ & $(0.42)$ & $(0.03)$ & $(0.04)$ & $(0.35)$ & $(0.26)$ \\
\hline \multirow[t]{2}{*}{ intrate-ukr* bank-uk } & $-2.75 * * *$ & -0.34 & $-9.47 * * *$ & 0.22 & $-1.08 * * *$ & $-0.82 *$ & 0.02 & 0.01 & $-0.55^{*}$ & 0.19 \\
\hline & $(0.59)$ & $(0.87)$ & $(1.00)$ & $(0.52)$ & $(0.15)$ & $(0.48)$ & $(0.08)$ & $(0.10)$ & $(0.29)$ & $(0.33)$ \\
\hline \multirow[t]{2}{*}{ intrate-euror* bank- euro } & $-2.51 * *$ & -1.04 & 1.36 & $2.35^{* * *} *$ & $-2.31 * * *$ & -0.71 & $0.15^{*}$ & 0.04 & -0.35 & -0.24 \\
\hline & (1.13) & (1.14) & (1.33) & $(0.61)$ & $(0.30)$ & $(0.54)$ & $(0.09)$ & $(0.06)$ & $(0.53)$ & $(0.52)$ \\
\hline \multirow[t]{2}{*}{ intrate-mexr* bank-mex } & $0.80^{*}$ & 1.23 & $2.72 * * *$ & -0.21 & -0.32 & 0.01 & $-0.10^{*}$ & -0.06 & 0.20 & 0.21 \\
\hline & $(0.45)$ & $(0.75)$ & $(0.76)$ & $(0.69)$ & $(0.21)$ & $(0.42)$ & $(0.06)$ & $(0.06)$ & $(0.20)$ & $(0.18)$ \\
\hline \multirow[t]{2}{*}{ qe-us* bank-us } & $0.94 * * *$ & 0.49 & $3.08 * * *$ & 0.44 & 0.15 & $-0.70^{*}$ & $-0.10 * *$ & 0.02 & $0.20 * * *$ & -0.02 \\
\hline & $(0.28)$ & $(0.31)$ & $(0.84)$ & $(0.28)$ & (0.09) & $(0.37)$ & $(0.04)$ & $(0.02)$ & $(0.07)$ & $(0.11)$ \\
\hline \multirow[t]{2}{*}{ qe-uk* bank-uk } & $0.70 *$ & 0.03 & 0.74 & -0.73 & -0.07 & 0.22 & -0.01 & -0.02 & $0.20 *$ & 0.22 \\
\hline & $(0.38)$ & $(0.40)$ & $(0.58)$ & $(0.48)$ & $(0.08)$ & $(0.44)$ & $(0.05)$ & $(0.07)$ & $(0.10)$ & $(0.24)$ \\
\hline \multirow[t]{2}{*}{ qe-euro* bank-euro } & 0.01 & -0.24 & -0.13 & $0.45^{* * *}$ & $0.10 *$ & 0.26 & $0.04 * * *$ & 0.01 & $0.13 * *$ & 0.06 \\
\hline & $(0.12)$ & $(0.17)$ & $(0.27)$ & $(0.13)$ & $(0.06)$ & $(0.17)$ & $(0.01)$ & $(0.01)$ & $(0.07)$ & $(0.07)$ \\
\hline Firm*Bank F.E. & Yes & Yes & Yes & Yes & Yes & Yes & Yes & Yes & Yes & Yes \\
\hline $\begin{array}{l}\text { State*Industry*Period } \\
\text { F.E. }\end{array}$ & Yes & Yes & Yes & Yes & Yes & Yes & Yes & Yes & Yes & Yes \\
\hline Observations & $7,110,956$ & $1,157,838$ & $7,110,956$ & $1,157,838$ & $7,110,956$ & $1,157,838$ & $7,110,956$ & $1,157,838$ & $5,602,833$ & 934,700 \\
\hline R-squared & 0.03 & 0.09 & 0.21 & 0.08 & 0.04 & 0.10 & 0.25 & 0.29 & 0.03 & 0.10 \\
\hline \multicolumn{11}{|c|}{$\begin{array}{l}\text { Notes: Estimates from OLS regressions. Observations are at the firm-bank-month level. A firm-bank-period observation is high (low) yield if the interest rate it pays on } \\
\text { its loans is above (below) the average loan interest rate, weighted by loan volume, paid by all firms in the previous quarter for all loans. The dependent variables are a } \\
\text { firm's: log loan volume, log maturity in months, collateral rate, loan rate and future default rate (at period t+12) with a given bank in a given month. intrate-countryr is } \\
\text { the residual of policy rate of country, where country stands for US, UK, Euro Area or Mexico. qe-country is the ratio of the yearly real change in central bank assets to } \\
\text { GDP of country. bank- country is an indicator that bank headquarters are in country. Other controls are listed in section } 2 \text { of the paper. Standard errors clustered at the } \\
\text { period and bank-industry level are reported in parentheses, where period is month. *significant at } 10 \text { percent, **significant at } 5 \text { percent, ***significant at } 1 \text { percent. }\end{array}$} \\
\hline
\end{tabular}




\section{Appendix}

Figure A1. Monetary Policies and Quantitative Easing June 2001- December 2015
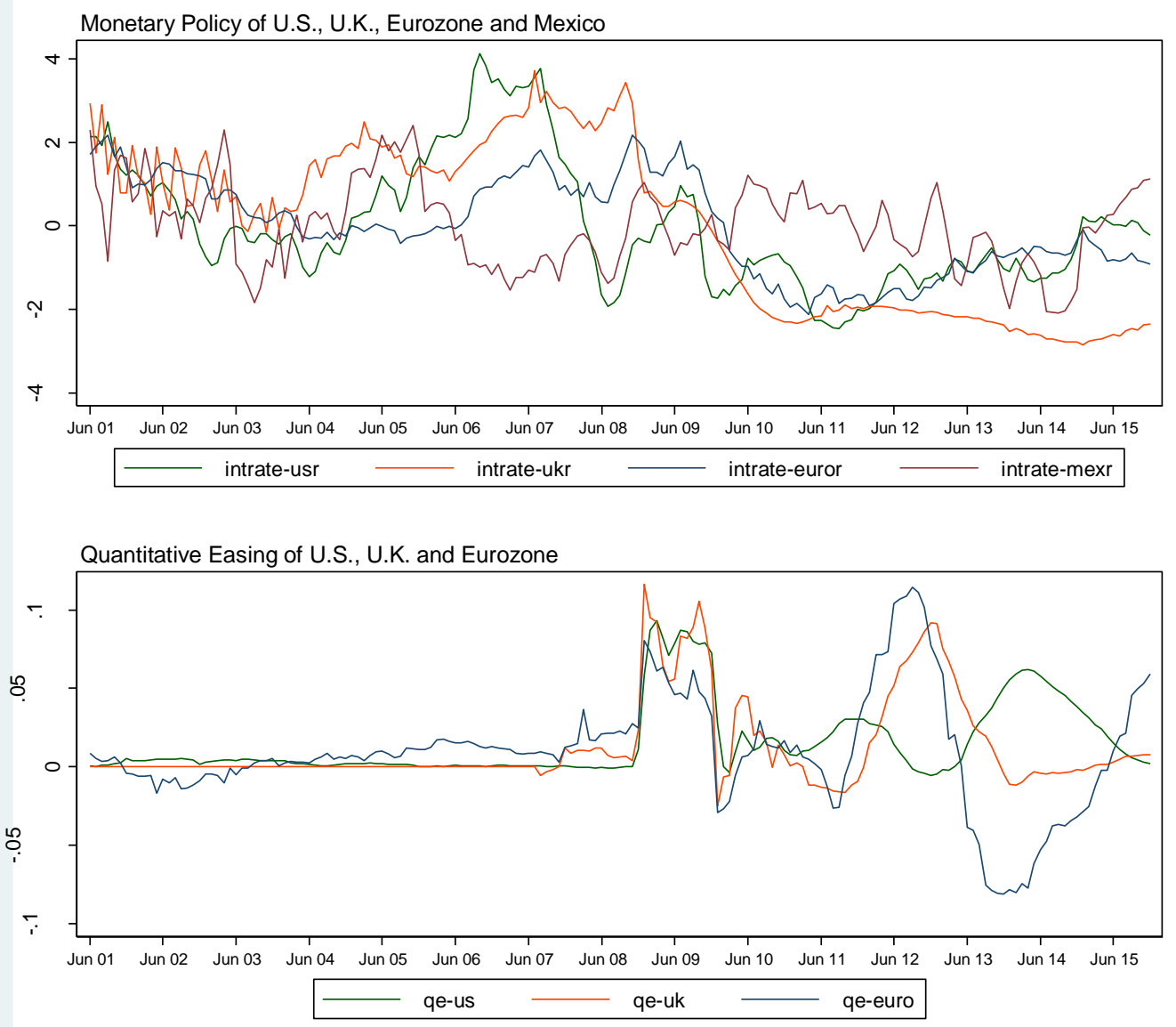

Notes: The first figure plots the residuals from regressions of the foreign monetary policies (Eonia rate for the Eurozone, Sonia rate for the U.K. and Fed Funds rate for the U.S.) on the annual growth rate of real GDP and CPI of each region over time, and the residuals from a regression of the Mexican monetary policy (Tasa de Fondeo Bancario) on the Fed Funds, and the annual growth rate of CPI and real GDP of both Mexico and the U.S. The second figure plots the evolution of quantitative easing over time in the Eurozone, U.K. and U.S., respectively. The quantitative easing is measured as the yearly real change in total balance sheet assets of each central bank (ECB, BoE and Federal Reserve) as a share of GDP in each region. 
Table A1. Variable Definitions (Loan-Month Level)

\begin{tabular}{|c|c|}
\hline Variable & Definition \\
\hline loan volume & $\begin{array}{l}\text { Value of the outstanding loans that a firm has from a given bank in a given } \\
\text { month (thousands of Mexican pesos) }\end{array}$ \\
\hline loan maturity & $\begin{array}{l}\text { Average maturity (in months) of the outstanding loans that a firm has from a } \\
\text { given bank in a given month, weighted by loan volume }\end{array}$ \\
\hline loan collateral & $\begin{array}{l}\text { Average fraction of the outstanding loans that a firm has from a given bank } \\
\text { in a given month that is covered by the firms' assets, weighted by loan } \\
\text { volume }\end{array}$ \\
\hline loan rate & $\begin{array}{l}\text { Average annualized loan rate of the outstanding loans that a firm has from a } \\
\text { given bank in a given month, weighted by loan volume }\end{array}$ \\
\hline loan default & $\begin{array}{l}\text { Average fraction of the outstanding loans that a firm has from a given bank } \\
\text { in a given month that have been delinquent for at least } 90 \text { days, weighted by } \\
\text { loan volume }\end{array}$ \\
\hline intrate-us & Fed Funds rate \\
\hline intrate-uk & Sonia rate \\
\hline intrate-euro & Eonia rate \\
\hline intrate-mex & Mexican Overnight Interest Rate (Tasa de Fondeo Interbancaria) \\
\hline intrate-usr & $\begin{array}{l}\text { Residual from regression of Fed Funds rate on annual growth rate of real } \\
\text { GDP-U.S. and CPI-U.S. }\end{array}$ \\
\hline intrate-ukr & $\begin{array}{l}\text { Residual from regression of Sonia rate on annual growth rate of real GDP- } \\
\text { U.K. and CPI-U.K. }\end{array}$ \\
\hline intrate-euror & $\begin{array}{l}\text { Residual from regression of Eonia rate on annual growth rate of real GDP- } \\
\text { Eurozone and CPI- Eurozone }\end{array}$ \\
\hline intrate-fgnr & $\begin{array}{l}\text { Average policy rate residuals of U.K., U.S. and Eurozone weighted by firm's } \\
\text { loan volume from each geographical region }\end{array}$ \\
\hline intrate-mexr & $\begin{array}{l}\text { Residual from regression of Overnight Mexican interest rate on Fed Funds } \\
\text { and annual growth rate of real GDP-mex, real GDP-U.S., CPI-mex and CPI- } \\
\text { U.S. }\end{array}$ \\
\hline qe-us & $\begin{array}{l}\text { Ratio of the yearly real change in the Federal Reserve's balance sheet assets } \\
\text { to U.S. GDP }\end{array}$ \\
\hline qe-uk & $\begin{array}{l}\text { Ratio of the yearly real change in the BoE's balance sheet assets to U.K. } \\
\text { GDP }\end{array}$ \\
\hline qe-euro & $\begin{array}{l}\text { Ratio of the yearly real change in the ECB's balance sheet assets to Eurozone } \\
\text { GDP }\end{array}$ \\
\hline qe-fgn & $\begin{array}{l}\text { Average QE of the U.S., U.K. and Eurozone areas weighted by firm's loan } \\
\text { volume from each geographical region }\end{array}$ \\
\hline bank-country & $\begin{array}{l}\text { Indicator variable that equals one if bank is headquartered in country, where } \\
\text { country is U.S., U.K., Eurozone or Mexico }\end{array}$ \\
\hline gdp-country & $\begin{array}{l}\text { Seasonally adjusted real GDP annual growth of country, where country is } \\
\text { U.S., U.K., Eurozone or Mexico }\end{array}$ \\
\hline cpi-country & $\begin{array}{l}\text { CPI annual growth of country, where country is U.S., U.K., Eurozone or } \\
\text { Mexico }\end{array}$ \\
\hline cds-country & $\begin{array}{l}\text { Sovereign credit default swaps (CDS) of country, where country is U.S., } \\
\text { U.K. or Eurozone }\end{array}$ \\
\hline
\end{tabular}

Notes: All intrate-country and qe-country variables are lagged 1-quarter. 
Table A1. Variable Definitions (Firm-Year Level)

\begin{tabular}{|c|c|}
\hline Variable & Definition \\
\hline loan volume ${ }^{Y}$ & $\begin{array}{l}\text { Value of the outstanding loans that a firm has from a given bank in a given } \\
\text { year (thousands of Mexican pesos) }\end{array}$ \\
\hline loan maturity ${ }^{\mathrm{Y}}$ & $\begin{array}{l}\text { Average maturity (in months) of the outstanding loans that a firm has from } \\
\text { a given bank in a given year, weighted by loan volume }\end{array}$ \\
\hline loan collateral ${ }^{\mathrm{Y}}$ & $\begin{array}{l}\text { Average fraction of the outstanding loans that a firm has from a given } \\
\text { bank in a given year that is covered by the firms' assets, weighted by loan } \\
\text { volume }\end{array}$ \\
\hline loan rate r $^{\mathrm{y}}$ & $\begin{array}{l}\text { Average annualized loan rate of the outstanding loans that a firm has from } \\
\text { a given bank in a given year, weighted by loan volume }\end{array}$ \\
\hline loan default ${ }^{Y}$ & $\begin{array}{l}\text { Average fraction of the outstanding loans that a firm has from a given } \\
\text { bank in a given year that are more than } 90 \text { days in arrears, weighted by } \\
\text { loan volume }\end{array}$ \\
\hline $\operatorname{exit}^{\mathrm{Y}}$ & $\begin{array}{l}\text { Proxy for firm survival due to loan defaults. Indicator variable that equals } \\
1 \text { if a firm in default exits permanently from the loan-level dataset in a } \\
\text { given year }\end{array}$ \\
\hline intrate $^{\mathrm{Y}}$-fgnr $*$ share $^{\mathrm{Y}}$-fgn & $\begin{array}{l}\text { Average annual residuals of monetary policies, weighted by the firm's } \\
\text { loan volume from each geographical region, times the one-year-lagged } \\
\text { share of a firm's loans with foreign banks }\end{array}$ \\
\hline intrate $^{\mathrm{Y}}$-mexr $*$ share $^{\mathrm{Y}}$-mex & $\begin{array}{l}\text { Residual of the regression of annual overnight Mexican rate on Fed Funds, } \\
\text { GDP-mex, GDP-us, CPI-mex, CPI-us- times the one-year-lagged share of } \\
\text { a firm's loans from Mexican banks }\end{array}$ \\
\hline $\mathrm{qe}^{\mathrm{Y}}$-fgn $*$ share $^{\mathrm{Y}}$-fgn & $\begin{array}{l}\text { Average annual QE, weighted by the firm's loan volume from each } \\
\text { geographical region, times the one-year-lagged share of a firm's loans } \\
\text { from foreign banks }\end{array}$ \\
\hline \multicolumn{2}{|l|}{ Variables from Orbis } \\
\hline $\begin{array}{l}\text { assets }^{Y} \\
\text { fixed assets } Y\end{array}$ & $\begin{array}{l}\text { Total firm assets (thousands of Mexican pesos) in a given year } \\
\text { Total fixed-assets of a firm (thousands of Mexican pesos) in a gi }\end{array}$ \\
\hline liabilities ${ }^{Y}$ & Total liabilities of a firm (thousands of Mexican pesos) in a given year \\
\hline non-current liabilities ${ }^{\mathrm{Y}}$ & $\begin{array}{l}\text { Liabilities of a firm in a given year with a maturity over } 12 \text { months } \\
\text { (thousands of Mexican pesos) }\end{array}$ \\
\hline current liabilities $^{Y}$ & $\begin{array}{l}\text { Liabilities of a firm in a given year with a maturity under } 12 \text { months } \\
\text { (thousands of Mexican pesos) }\end{array}$ \\
\hline employment ${ }^{\mathrm{Y}}$ & Total number of employees of a firm in a given year \\
\hline
\end{tabular}


Table A2. Summary Statistics Monthly Bank-level Data

\begin{tabular}{|c|c|c|c|c|c|}
\hline & $\begin{array}{c}\text { (1) } \\
\text { All banks }\end{array}$ & $\begin{array}{c}(2) \\
\text { Mex banks } \\
\text { (large) }\end{array}$ & $\begin{array}{c}\text { (3) } \\
\text { Euro Area } \\
\text { Banks }\end{array}$ & $\begin{array}{c}\text { (4) } \\
\text { U.K. Banks }\end{array}$ & $\begin{array}{c}\text { (5) } \\
\text { U.S. Banks }\end{array}$ \\
\hline \multicolumn{6}{|c|}{ Balance Sheet Information } \\
\hline \multirow[t]{2}{*}{ Assets (logs) } & 4.4 & 6.0 & 6.4 & 5.8 & 6.6 \\
\hline & (1.8) & $(0.6)$ & $(0.1)$ & $(0.5)$ & $(0.5)$ \\
\hline \multirow[t]{2}{*}{ Liquidity ratio } & 0.09 & 0.09 & 0.12 & 0.14 & 0.10 \\
\hline & $(0.05)$ & $(0.02)$ & $(0.03)$ & $(0.05)$ & $(0.03)$ \\
\hline \multirow[t]{2}{*}{ Capital ratio } & 0.09 & 0.07 & 0.09 & 0.07 & 0.12 \\
\hline & $(0.07)$ & $(0.03)$ & $(0.08)$ & $(0.02)$ & $(0.01)$ \\
\hline \multirow[t]{2}{*}{ Deposit ratio } & 0.43 & 0.49 & 0.47 & 0.58 & 0.43 \\
\hline & $(0.14)$ & $(0.08)$ & $(0.09)$ & $(0.06)$ & $(0.06)$ \\
\hline \multirow[t]{2}{*}{ ROA } & 1.0 & 1.1 & 1.7 & 0.8 & 1.5 \\
\hline & $(2.0)$ & $(0.4)$ & $(0.7)$ & $(0.6)$ & $(0.7)$ \\
\hline \multirow[t]{2}{*}{ ROE } & 12.9 & 16.6 & 19.9 & 11.6 & 12.3 \\
\hline & $(11.5)$ & $(6.8)$ & (7.9) & $(9.1)$ & $(6.3)$ \\
\hline \multirow[t]{2}{*}{ Commercial Credit } & 0.34 & 0.34 & 0.28 & 0.29 & 0.23 \\
\hline & $(0.16)$ & $(0.10)$ & $(0.06)$ & $(0.05)$ & $(0.06)$ \\
\hline \multirow[t]{2}{*}{ Market share } & 0.06 & 0.14 & 0.16 & 0.11 & 0.15 \\
\hline & $(0.07)$ & $(0.03)$ & $(0.06)$ & $(0.03)$ & $(0.03)$ \\
\hline \multicolumn{6}{|c|}{ Commercial Loan Portfolio Composition (\%) } \\
\hline Agriculture & 4 & 7 & 5 & 8 & 6 \\
\hline Construction & 9 & 9 & 16 & 9 & 6 \\
\hline Manufacturing & 19 & 21 & 24 & 24 & 26 \\
\hline Retail & 38 & 35 & 31 & 36 & 42 \\
\hline Services & 22 & 18 & 15 & 15 & 12 \\
\hline Other Sectors & 8 & 10 & 8 & 9 & 8 \\
\hline
\end{tabular}

Notes: Assets are measured in logs of billions of real Mexican Pesos at January 2008 prices. Liquidity ratio is the ratio of liquid assets to total assets. Capital ratio is the ratio of equity over total assets. Deposit ratio is the ratio of total deposits to assets. $R O A$ is the return on assets measured as ratio of net income to assets. $R O E$ is the return on equity measured as the ratio of net income to equity. Commercial credit is the ratio of commercial credit to total assets. Market share is the bank's market share of commercial credit. Standard deviations are reported in parentheses. Statistics cover the period of June 2001 to December 2015. The panel of Commercial Loan Portfolio Composition denotes the share of commercial credit allocated by a bank to firms in the Agriculture, Construction, Manufacturing, Retail, Services and Other Sectors. 
Table A3. Summary Statistics Monthly Data by Firms' Yield

\begin{tabular}{|c|c|c|c|c|c|c|}
\hline \multirow[b]{3}{*}{ Variable } & (1) & (2) & (3) & (4) & (5) & (6) \\
\hline & \multicolumn{3}{|c|}{ High-yield firms } & \multicolumn{3}{|c|}{ Low-yield firms } \\
\hline & Mean & Median & St. Dev & Mean & Median & St. Dev \\
\hline Loan Volume & 842 & 302 & 1,692 & 4,908 & 3,332 & 4,697 \\
\hline Loan Maturity & 33.5 & 36.0 & 19.6 & 32.4 & 24.0 & 28.8 \\
\hline Loan Collateral & 0.24 & 0.00 & 0.43 & 0.45 & 0.23 & 0.83 \\
\hline Loan Rate & 16.2 & 16.1 & 7.4 & 8.2 & 9.3 & 2.1 \\
\hline Loan Default & 0.08 & 0.00 & 0.27 & 0.03 & 0.00 & 0.17 \\
\hline
\end{tabular}

Notes: High (Low) yield firms - A firm-bank-month observation has high (low) yield if the loan rate the firm pays on its loan is above (below) the average loan interest rate, weighted by loan volume, paid by all firms in all loans in that month.

Table A4. Characteristics of firms borrowing from foreign banks and the largest domestic bank

\begin{tabular}{lcc}
\hline \hline & $(1)$ & $(2)$ \\
& Loan Volume $(\operatorname{logs})$ & Total Assets $(\operatorname{logs})$ \\
\hline bank-us & 0.17 & 0.25 \\
& $(0.40)$ & $(0.97)$ \\
bank-uk & 0.70 & 0.66 \\
& $(0.45)$ & $(1.67)$ \\
bank-euro & 0.31 & 0.59 \\
& $(0.26)$ & $(0.91)$ \\
Observations & & 13,287 \\
R-squared & 642,309 & 0.88 \\
\hline
\end{tabular}

Notes: Estimates from OLS regressions. Each observation represents a firm-year pair. The sample is constrained to firms borrowing from foreign banks and the largest domestic bank. bank-country is an indicator variable that equals one if a bank is from country, where country stands for the U.S., U.K., and the Euro Area (the omitted category corresponds to the largest Mexican bank). The dependent variables correspond to the total bank loan volume and total assets (both in logs) of a firm at a given year. All regressions include fixed effects at the state*industry*year level. Standard errors that are clustered at the year and state*industry level are reported in parentheses. ${ }^{*}$ significant at $10 \%, * *$ significant at $5 \%, * * *$ significant at $1 \%$. 
Table A5. Characteristics of firms in Orbis and rest of firms

\begin{tabular}{lccc}
\hline \hline & $(1)$ & $(2)$ & $(3)$ \\
& Orbis & Non-Orbis & $\begin{array}{c}\text { Difference } \\
\text { (t-stats) }\end{array}$ \\
\hline firm age & 15.5 & 13.9 & 1.8 \\
loan volume (logs) & $(10.0)$ & $(13.9)$ & $(34.7)$ \\
loan maturity (months) & 16.0 & 15.0 & 1.0 \\
loan collateral & $(2.4)$ & $(2.7)$ & $(118.3)$ \\
& 30.0 & 34.2 & -4.2 \\
loan rate & $(28.5)$ & $(28.1)$ & $(-38.8)$ \\
& 0.30 & 0.27 & 0.03 \\
loan default & $(0.42)$ & $(0.5)$ & $(15.8)$ \\
& 13.8 & 15.1 & 1.3 \\
& $(5.1)$ & $(5.4)$ & $(-63.7)$ \\
& 0.07 & 0.13 & -0.05 \\
& $(0.23)$ & $(0.3)$ & $(-45.4)$ \\
\hline
\end{tabular}

Notes: The first two columns report means and standard deviations (in parentheses) of the characteristics of firms - present in the loan-level dataset - depending on whether they are in the Orbis data set. The third column presents the mean difference of each variable between the two groups (with its $t$-stat in parentheses). Firm age is measured in years; loan volume is measured in thousands of Mexican pesos at January 2008 prices; loan maturity is the average duration of the loans; loan collateral is the fraction of loans that are guaranteed by firm assets; loan rate is the loan rate charged by banks in percent; loan default is the fraction of loans in arrears for more than 90 days. 
Table A6. Probability that a firm switches banks

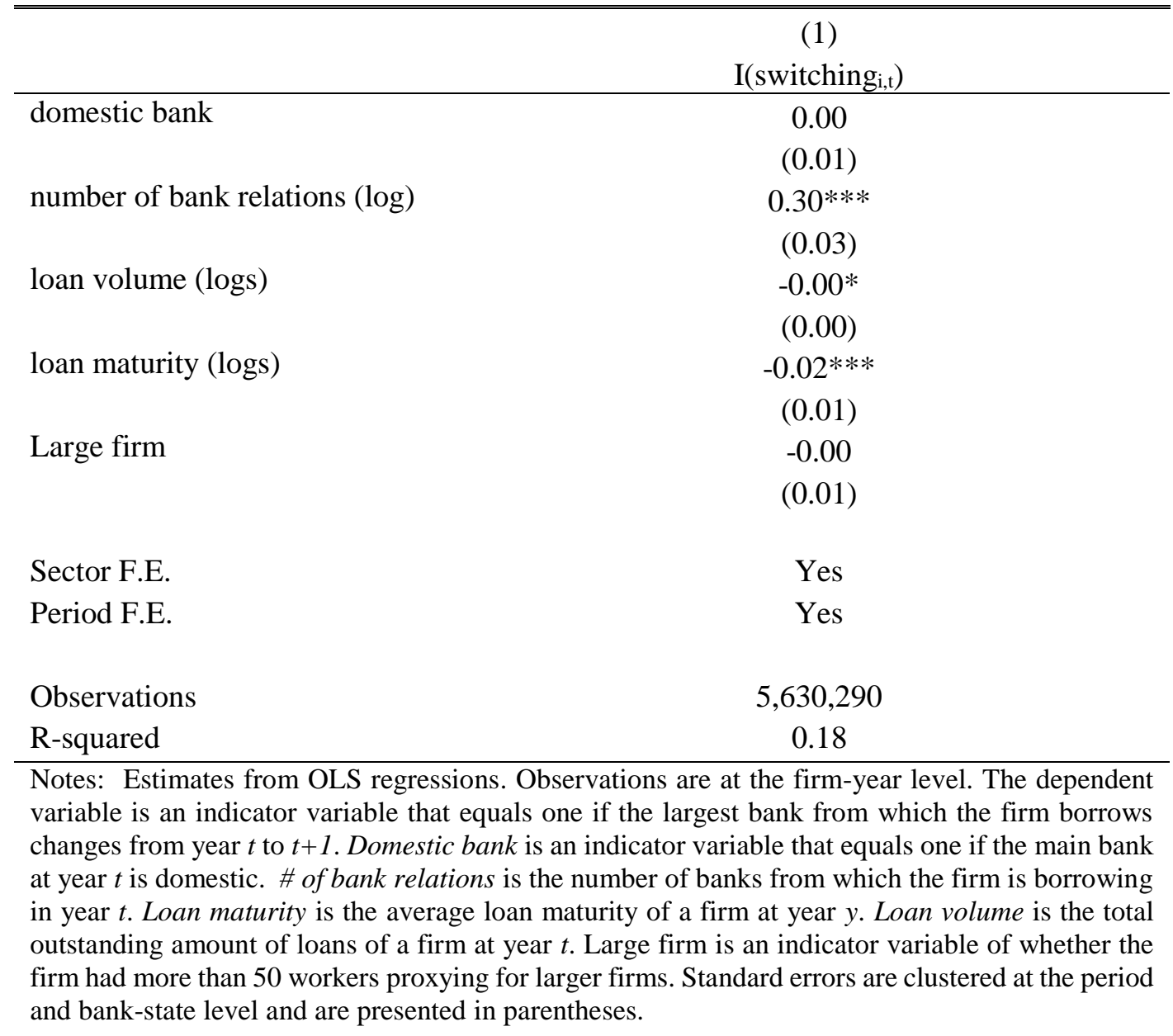


Table A7. Impact of International Monetary Policies on Domestic Loan Volume (June 2001 - Nov 2009)

\begin{tabular}{|c|c|c|c|c|}
\hline & $(1)$ & $(2)$ & (3) & $(4)$ \\
\hline intrate-usr & $\begin{array}{l}-0.44 * \\
(0.24)\end{array}$ & & & \\
\hline intrate-usr * bank-us & $\begin{array}{c}-1.08 * * \\
(0.54)\end{array}$ & $\begin{array}{c}-1.53^{* *} \\
(0.60)\end{array}$ & $\begin{array}{c}-1.69 * * * \\
(0.50)\end{array}$ & $\begin{array}{c}-2.06 * * * \\
(0.78)\end{array}$ \\
\hline intrate-ukr & $\begin{array}{c}0.85^{* *} \\
(0.39)\end{array}$ & & & \\
\hline intrate-ukr * bank-uk & $\begin{array}{c}-2.65 * * * \\
(0.95)\end{array}$ & $\begin{array}{c}-4.81 * * * \\
(1.22)\end{array}$ & $\begin{array}{c}-5.60 * * * \\
(1.08)\end{array}$ & $\begin{array}{c}-5.90 * * * \\
(1.82)\end{array}$ \\
\hline intrate-euror & $\begin{array}{c}1.29 * * \\
(0.54)\end{array}$ & & & \\
\hline intrate-euror * bank-euro & $\begin{array}{c}0.89 \\
(0.94)\end{array}$ & $\begin{array}{c}0.83 \\
(1.08)\end{array}$ & $\begin{array}{c}0.74 \\
(0.88)\end{array}$ & $\begin{array}{c}0.77 \\
(1.43)\end{array}$ \\
\hline intrate-mexr & $\begin{array}{c}-0.91 * * * \\
(0.30)\end{array}$ & & & \\
\hline intrate-mexr $*$ bank-mex & $\begin{array}{l}-0.18 \\
(0.39)\end{array}$ & $\begin{array}{c}0.63 \\
(0.84)\end{array}$ & $\begin{array}{c}0.39 \\
(0.65)\end{array}$ & $\begin{array}{c}0.74 \\
(1.08)\end{array}$ \\
\hline $\begin{array}{l}\text { Firm*Bank F.E. } \\
\text { State*Industry*Period F.E. } \\
\text { Firm*Period F.E. } \\
\text { Firms borrowing from more than } 1 \\
\text { bank }\end{array}$ & $\begin{array}{l}\text { Yes } \\
\text { No } \\
\text { No } \\
\text { No }\end{array}$ & $\begin{array}{l}\text { Yes } \\
\text { Yes } \\
\text { No } \\
\text { No }\end{array}$ & $\begin{array}{l}\text { Yes } \\
\text { Yes } \\
\text { No } \\
\text { Yes }\end{array}$ & $\begin{array}{c}\text { Yes } \\
- \\
\text { Yes } \\
\text { Yes }\end{array}$ \\
\hline $\begin{array}{l}\text { Observations } \\
\text { R-squared }\end{array}$ & $\begin{array}{c}4,309,232 \\
0.01\end{array}$ & $\begin{array}{c}4,309,232 \\
0.03\end{array}$ & $\begin{array}{c}1,367,706 \\
0.05\end{array}$ & $\begin{array}{c}1,367,706 \\
0.50\end{array}$ \\
\hline
\end{tabular}

Notes: Estimates from OLS regressions for the period up to November 2009. Observations are at the firmbank-month level. The dependent variable is the firm's loan volume from a given bank in a given month. intrate-countryr is the residual of policy rate of country, where country stands for US, UK, Euro Area or Mexico. bank-country is an indicator variable that equals 1 if bank is from country. Other controls are listed in section 2 of the paper. Fixed effects already absorbed by other fixed effects are indicated by “- ". Standard errors clustered at the period and bank-industry level are reported in parentheses, where period is month. *significant at 10 percent, ${ }^{* *}$ significant at 5 percent, ${ }^{* * *}$ significant at 1 percent. 


\section{Table A8. Impact of International Monetary Policies on Balance Sheet Variables of Banks}

\begin{tabular}{lccccc}
\hline \hline & $(1)$ & $(2)$ & $(3)$ & $(4)$ & $(5)$ \\
& Assets & $\begin{array}{c}\text { Overdue } \\
\text { Credit }\end{array}$ & Liabilities & $\begin{array}{c}\text { Short-term } \\
\text { Liabilities }\end{array}$ & $\begin{array}{c}\text { Foreign } \\
\text { Liabilities }\end{array}$ \\
\hline intrate-fgnr* bank-fgn & $-1.55^{*}$ & $-0.36^{* * *}$ & $-2.52^{* * *}$ & -8.10 & $-6.09 * * *$ \\
& $(0.79)$ & $(0.09)$ & $(0.93)$ & $(6.05)$ & $(1.80)$ \\
intrate-mexr * bank-mex & -0.45 & 0.06 & -0.21 & 2.69 & $-3.12^{*}$ \\
& $(0.70)$ & $(0.10)$ & $(0.75)$ & $(3.28)$ & $(1.76)$ \\
qe-fgn * bank-fgn & $1.62 * * *$ & $0.13^{* * *}$ & $1.51^{* * *}$ & 1.85 & $1.87 * *$ \\
& $(0.25)$ & $(0.03)$ & $(0.27)$ & $(1.27)$ & $(0.73)$ \\
Period F.E. & & & & & \\
Bank F.E. & Yes & Yes & Yes & Yes & Yes \\
Yes & Yes & Yes & Yes & Yes \\
Observations & 2,627 & 2,591 & 2,627 & 2,593 & 2,593 \\
R-squared & 0.97 & 0.16 & 0.96 & 0.80 & 0.85 \\
\hline Not & & & & & \\
\hline
\end{tabular}

Notes: Estimates from OLS regressions. Observations are at the bank-month level. Assets are the total assets (in logs) of a bank in a given month. Overdue credit is the ratio of credit in arrears to total credit of a bank in a given month. Liabilities are the total liabilities (in logs) of a bank in a given month. Short-term liabilities are the short-term and immediate liabilities (in logs) in a given month. Foreign Liabilities are the liabilities from foreign banks and central banks (in logs) in a given month. intrate-fgnr is the residual of the interest rate of the country in which the foreign bank is headquartered in, on its respective GDP and CPI growth. fgn-bank is an indicator of foreign bank. intrate-mexr is the residual of policy rate of Mexico. qe-fgn is the QE of the foreign country in which the bank is headquartered in, with QE measured as the ratio of the yearly change in central bank assets to GDP. Controls include linear time trends for banks headquartered in Mexico, the Eurozone, U.K. and U.S. Additional control variables are listed in section 2 of the paper. Standard errors clustered at the period level are in parentheses, where period is month level. *significant at 10 percent, $* *$ significant at 5 percent, $* * *$ significant at 1 percent. 
Table A9. Impact of International Monetary Policies on Domestic Credit Margins of Firms in Tradeable and Non-Tradeable Sectors

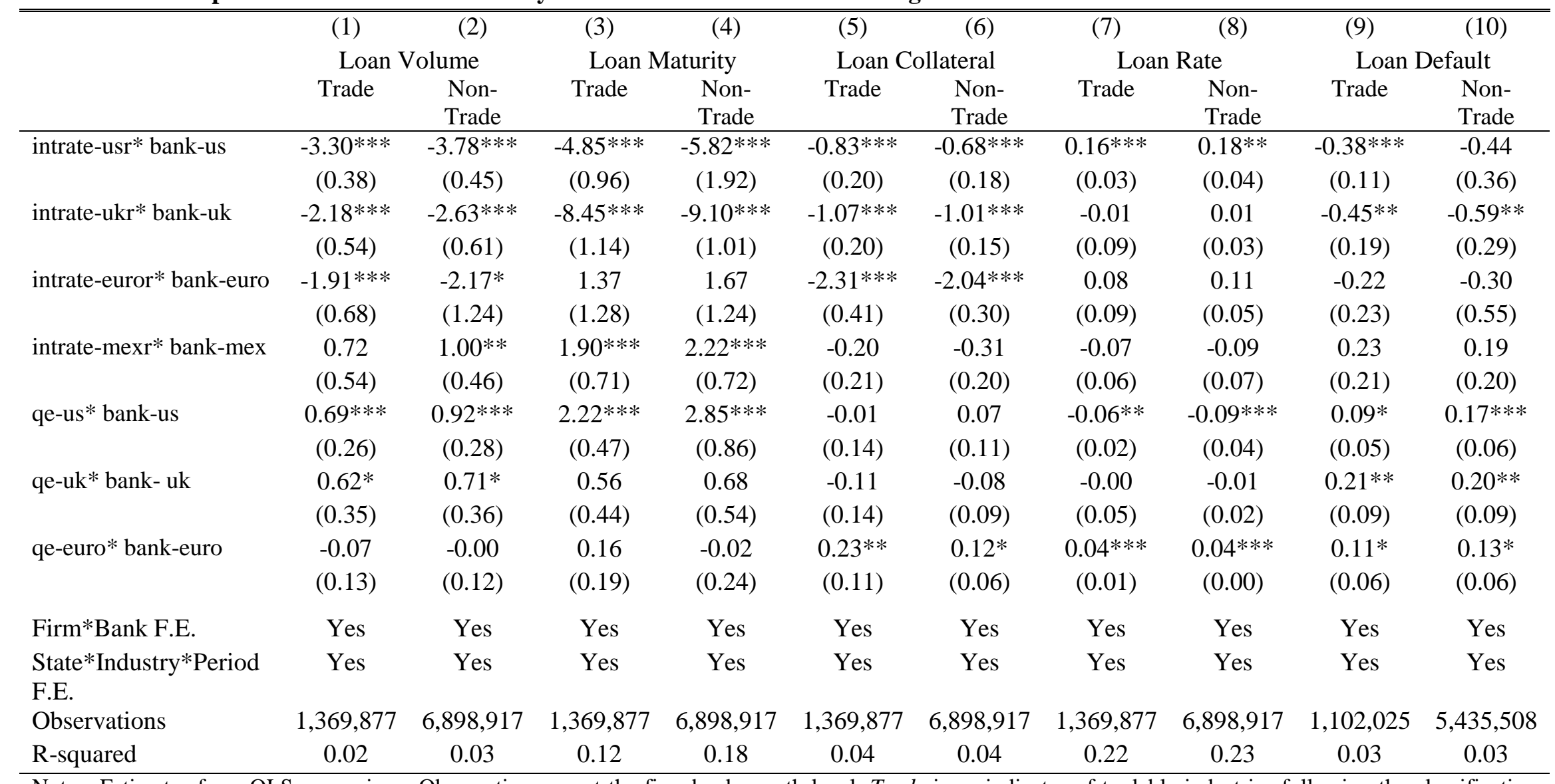

Notes: Estimates from OLS regressions. Observations are at the firm-bank-month level. Trade is an indicator of tradable industries following the classification outlined by Amir and Mian (2012), whereas Non-trade are the remaining industries. The dependent variables are: a firm's log loan volume, maturity, collateral rate, loan interest rate and default rate at $t+12$ with a given bank in a given month. intrate-countryr is the residual of the policy rate of country, where country stands for US, UK, Euro Area or Mexico. qe-country is the ratio of the yearly real change in central bank assets to GDP of country. country-bank is an indicator that bank is from country. Other controls are listed in section 2 of the paper. Standard errors are reported in parentheses and are clustered at the period and bank-industry level, where period is month. *significant at 10 percent, $* *$ significant at 5 percent, $* * *$ significant at 1 percent. 
Table A10. Impact of International Monetary Policies on Domestic Credit Margins of Firms from Northern and Southern States

\begin{tabular}{|c|c|c|c|c|c|c|c|c|c|c|}
\hline & (1) & (2) & (3) & (4) & (5) & (6) & (7) & (8) & (9) & $(10)$ \\
\hline & \multicolumn{2}{|c|}{ Loan Volume } & \multicolumn{2}{|c|}{ Loan Maturity } & \multicolumn{2}{|c|}{ Loan Collateral } & \multicolumn{2}{|c|}{ Loan Rate } & \multicolumn{2}{|c|}{ Loan Default } \\
\hline & North & South & North & South & North & South & North & South & North & South \\
\hline intrate-usr * bank-us & $\begin{array}{c}-3.21 * * * \\
(0.76)\end{array}$ & $\begin{array}{c}-3.95 * * * \\
(0.51)\end{array}$ & $\begin{array}{c}-6.03 * * * \\
(1.44)\end{array}$ & $\begin{array}{c}-5.41 * * * \\
(1.81)\end{array}$ & $\begin{array}{c}-0.56 * * * \\
(0.20)\end{array}$ & $\begin{array}{c}-0.79 * * * \\
(0.18)\end{array}$ & $\begin{array}{c}0.16 * * \\
(0.09)\end{array}$ & $\begin{array}{c}0.19 * * \\
(0.11)\end{array}$ & $\begin{array}{c}-0.67 * * \\
(0.26)\end{array}$ & $\begin{array}{l}-0.29 \\
(0.34)\end{array}$ \\
\hline intrate-ukr $*$ bank-uk & $\begin{array}{c}-2.26 * * * \\
(0.70)\end{array}$ & $\begin{array}{c}-2.75 * * * \\
(0.69)\end{array}$ & $\begin{array}{c}-8.79 * * * \\
(0.89)\end{array}$ & $\begin{array}{c}-9.13 * * * \\
(0.93)\end{array}$ & $\begin{array}{c}-1.03 * * * \\
(0.16)\end{array}$ & $\begin{array}{c}-1.03 * * * \\
(0.15)\end{array}$ & $\begin{array}{c}0.00 \\
(0.01)\end{array}$ & $\begin{array}{c}0.01 \\
(0.02)\end{array}$ & $\begin{array}{c}-0.78 * * * \\
(0.21)\end{array}$ & $\begin{array}{c}-0.43 \\
(0.31)\end{array}$ \\
\hline intrate-euror * bank- euro & $\begin{array}{c}-2.74 * * * \\
(0.89)\end{array}$ & $\begin{array}{l}-1.95 \\
(1.36)\end{array}$ & $\begin{array}{c}1.35 \\
(1.31)\end{array}$ & $\begin{array}{c}1.73 \\
(1.07)\end{array}$ & $\begin{array}{c}-2.23 * * * \\
(0.26)\end{array}$ & $\begin{array}{c}-2.04 * * * \\
(0.32)\end{array}$ & $\begin{array}{c}0.12 \\
(0.08)\end{array}$ & $\begin{array}{c}0.10 \\
(0.09)\end{array}$ & $\begin{array}{l}-0.43 \\
(0.38)\end{array}$ & $\begin{array}{l}-0.18 \\
(0.54)\end{array}$ \\
\hline intrate-mexr $*$ bank-mex & $\begin{array}{c}0.81 \\
(0.75)\end{array}$ & $\begin{array}{c}1.05 * * * \\
(0.38)\end{array}$ & $\begin{array}{c}2.11 * * * \\
(0.51)\end{array}$ & $\begin{array}{c}2.21 * * \\
(0.93)\end{array}$ & $\begin{array}{l}-0.10 \\
(0.26)\end{array}$ & $\begin{array}{c}-0.44 * * \\
(0.20)\end{array}$ & $\begin{array}{c}-0.08 \\
(0.11)\end{array}$ & $\begin{array}{c}-0.08 \\
(0.13)\end{array}$ & $\begin{array}{c}0.27 \\
(0.18)\end{array}$ & $\begin{array}{c}0.14 \\
(0.22)\end{array}$ \\
\hline qe-us * bank-us & $\begin{array}{c}0.95 * * * \\
(0.32)\end{array}$ & $\begin{array}{c}0.85 * * * \\
(0.26)\end{array}$ & $\begin{array}{c}2.52 * * * \\
(0.72)\end{array}$ & $\begin{array}{c}2.82 * * * \\
(0.83)\end{array}$ & $\begin{array}{c}0.02 \\
(0.14)\end{array}$ & $\begin{array}{c}0.08 \\
(0.10)\end{array}$ & $\begin{array}{c}-0.07 * * * \\
(0.02)\end{array}$ & $\begin{array}{c}-0.09 * * * \\
(0.03)\end{array}$ & $\begin{array}{c}0.13 \\
(0.09)\end{array}$ & $\begin{array}{c}0.16 * * * \\
(0.05)\end{array}$ \\
\hline qe-uk $*$ bank-uk & $\begin{array}{l}0.81 * \\
(0.50)\end{array}$ & $\begin{array}{l}0.66^{*} \\
(0.37)\end{array}$ & $\begin{array}{c}0.62 \\
(0.46)\end{array}$ & $\begin{array}{c}0.68 \\
(0.55)\end{array}$ & $\begin{array}{l}-0.10 \\
(0.10)\end{array}$ & $\begin{array}{c}-0.08 \\
(0.09)\end{array}$ & $\begin{array}{c}-0.01 \\
(0.03)\end{array}$ & $\begin{array}{l}-0.01 \\
(0.02)\end{array}$ & $\begin{array}{c}0.16 \\
(0.10)\end{array}$ & $\begin{array}{c}0.22 * * \\
(0.09)\end{array}$ \\
\hline qe-euro * bank-euro & $\begin{array}{c}0.16 \\
(0.31)\end{array}$ & $\begin{array}{l}-0.10 \\
(0.13)\end{array}$ & $\begin{array}{c}0.08 \\
(0.29)\end{array}$ & $\begin{array}{c}-0.02 \\
(0.21)\end{array}$ & $\begin{array}{c}0.11 \\
(0.06)\end{array}$ & $\begin{array}{c}0.15 * * \\
(0.07)\end{array}$ & $\begin{array}{c}0.03 * * * \\
(0.00)\end{array}$ & $\begin{array}{c}0.04 * * * \\
(0.00)\end{array}$ & $\begin{array}{c}0.10 \\
(0.09)\end{array}$ & $\begin{array}{c}0.14 * * \\
(0.06)\end{array}$ \\
\hline Firm*Bank F.E. & Yes & Yes & Yes & Yes & Yes & Yes & Yes & Yes & Yes & Yes \\
\hline $\begin{array}{l}\text { State*Industry*Period } \\
\text { F.E. }\end{array}$ & Yes & Yes & Yes & Yes & Yes & Yes & Yes & Yes & Yes & Yes \\
\hline Observations & $3,034,567$ & $5,234,227$ & $3,034,567$ & $5,234,227$ & $3,034,567$ & $5,234,227$ & $3,034,567$ & $5,234,227$ & $2,428,606$ & $4,108,927$ \\
\hline R-squared & 0.03 & 0.03 & 0.15 & 0.18 & 0.04 & 0.03 & 0.21 & 0.24 & 0.03 & 0.03 \\
\hline
\end{tabular}




\section{Table A11. Impact of International Monetary Policies on Loan Volume Controlling for}

Bank Characteristics

\begin{tabular}{|c|c|c|c|c|}
\hline & $(1)$ & $(2)$ & (3) & $(4)$ \\
\hline intrate-usr & $\begin{array}{l}-0.27 * \\
(0.16)\end{array}$ & & & \\
\hline intrate-usr * bank-us & $\begin{array}{c}-2.83 * * * \\
(0.34)\end{array}$ & $\begin{array}{c}-3.39 * * * \\
(0.37)\end{array}$ & $\begin{array}{c}-2.92 * * * \\
(0.33)\end{array}$ & $\begin{array}{c}-3.04 * * * \\
(0.50)\end{array}$ \\
\hline intrate-ukr & $\begin{array}{l}-0.08 \\
(0.31)\end{array}$ & & & \\
\hline intrate-ukr * bank-uk & $\begin{array}{c}-1.15^{* * *} \\
(0.48)\end{array}$ & $\begin{array}{c}-2.49 * * * \\
(0.61)\end{array}$ & $\begin{array}{c}-2.31 * * * \\
(0.45)\end{array}$ & $\begin{array}{c}-2.67 * * * \\
(0.70)\end{array}$ \\
\hline intrate-euror & $\begin{array}{c}1.84 * * * \\
(0.62)\end{array}$ & & & \\
\hline intrate-euror * bank-euro & $\begin{array}{c}-2.32 * * * \\
(0.81)\end{array}$ & $\begin{array}{l}-1.90^{*} \\
(1.04)\end{array}$ & $\begin{array}{c}-1.14 * * \\
(0.53)\end{array}$ & $\begin{array}{l}-0.64 \\
(0.82)\end{array}$ \\
\hline intrate-mexr & $\begin{array}{c}-0.78 * * * \\
(0.19)\end{array}$ & & & \\
\hline intrate-mexr $*$ bank-mex & $\begin{array}{c}0.00 \\
(0.32)\end{array}$ & $\begin{array}{c}0.80 \\
(0.50)\end{array}$ & $\begin{array}{l}-0.03 \\
(0.51)\end{array}$ & $\begin{array}{l}-0.01 \\
(0.80)\end{array}$ \\
\hline qe-us & $\begin{array}{c}-0.46 * * * \\
(0.11)\end{array}$ & & & \\
\hline qe-us * bank-us & $\begin{array}{c}0.64 * * * \\
(0.25)\end{array}$ & $\begin{array}{c}0.98 * * * \\
(0.25)\end{array}$ & $\begin{array}{c}0.94 * * * \\
(0.19)\end{array}$ & $\begin{array}{c}1.01 * * * \\
(0.28)\end{array}$ \\
\hline qe-uk & $\begin{array}{l}-0.08 \\
(0.11)\end{array}$ & & & \\
\hline qe-uk * bank-uk & $\begin{array}{c}0.59 * * * \\
(0.18)\end{array}$ & $\begin{array}{l}0.65^{*} \\
(0.34)\end{array}$ & $\begin{array}{l}0.53 * \\
(0.31)\end{array}$ & $\begin{array}{c}0.45 \\
(0.47)\end{array}$ \\
\hline qe-euro & $\begin{array}{l}0.13^{*} \\
(0.08)\end{array}$ & & & \\
\hline qe-euro * bank-euro & $\begin{array}{c}0.39 * * * \\
(0.12)\end{array}$ & $\begin{array}{c}0.13 \\
(0.15)\end{array}$ & $\begin{array}{c}0.17 \\
(0.12)\end{array}$ & $\begin{array}{c}0.13 \\
(0.19)\end{array}$ \\
\hline Firm*Bank F.E. & Yes & Yes & Yes & Yes \\
\hline State*Industry*Period F.E. & No & Yes & Yes & - \\
\hline Firm*Period F.E. & No & No & No & Yes \\
\hline Firms borrowing from more than 1 bank & No & No & Yes & Yes \\
\hline Observations & $8,268,794$ & $8,268,794$ & $3,020,617$ & $3,020,617$ \\
\hline R-squared & 0.01 & 0.03 & 0.04 & 0.48 \\
\hline
\end{tabular}

Notes: Estimates from OLS regressions. Observations are at the firm-bank-month level. All regressions control for time-varying bank size (in logs) as well as liquidity and capital ratio of a given bank at a given month. The dependent variable is the volume of loans, in logs, from a firm with a bank in a given month. intrate-countryr is the residual of policy rate of country, where country stands for US, UK, Euro Area or Mexico. qe-country is the ratio of the yearly real change in central bank assets to GDP of country. bankcountry is an indicator that bank headquarters are in country. Other controls are listed in section 2 of the paper. Fixed effects already absorbed by other fixed effects are indicated by “-“. Standard errors are reported in parentheses and are clustered at the period and bank-industry level, where period is month. *significant at 10 percent, $* *$ significant at 5 percent, ${ }^{* * *}$ significant at 1 percent. 
Table A12. Impact of Instrumented Fed Fund Rates on Domestic Loan Volume

\begin{tabular}{|c|c|c|c|c|c|c|c|c|c|c|c|c|}
\hline & (1) & (2) & (3) & (4) & $(5)$ & (6) & (7) & $(8)$ & (9) & (10) & (11) & (12) \\
\hline chg_intrate-us* bank-us & $\begin{array}{c}-0.06 * * * \\
(0.01)\end{array}$ & $\begin{array}{c}-0.10 * * * \\
(0.01)\end{array}$ & & & & & & & & & & \\
\hline instr-fedf ${ }_{\mathrm{m} 1} *$ bank-us & & & $\begin{array}{c}-0.05 * * * \\
(0.01)\end{array}$ & $\begin{array}{c}-0.06 * * * \\
(0.01)\end{array}$ & & & & & & & & \\
\hline instr-fedf $\mathrm{m}_{3} *$ bank-us & & & & & $\begin{array}{c}-0.12 * * * \\
(0.03)\end{array}$ & $\begin{array}{c}-0.13 * * * \\
(0.03)\end{array}$ & & & & & & \\
\hline instr-edollar $\mathrm{q}_{\mathrm{q} 2} *$ bank-us & & & & & & & $\begin{array}{c}-0.16 * * * \\
(0.02)\end{array}$ & $\begin{array}{c}-0.19 * * * \\
(0.02)\end{array}$ & & & & \\
\hline instr-edollar ${ }_{\mathrm{q} 3} *$ bank-us & & & & & & & & & $\begin{array}{c}-0.14 * * * \\
(0.02)\end{array}$ & $\begin{array}{c}-0.18 * * * \\
(0.02)\end{array}$ & & \\
\hline instr-edollar $\mathrm{r}_{\mathrm{q}} *$ bank-us & & & & & & & & & & & $\begin{array}{c}-0.10 * * * \\
(0.02)\end{array}$ & $\begin{array}{c}-0.14 * * * \\
(0.02)\end{array}$ \\
\hline intrate-mexr* bank-mex & $\begin{array}{c}0.10 \\
(0.25)\end{array}$ & $\begin{array}{c}0.05 \\
(0.30)\end{array}$ & $\begin{array}{c}0.13 \\
(0.24)\end{array}$ & $\begin{array}{c}0.17 \\
(0.28)\end{array}$ & $\begin{array}{c}0.13 \\
(0.24)\end{array}$ & $\begin{array}{c}0.18 \\
(0.28)\end{array}$ & $\begin{array}{c}0.13 \\
(0.24)\end{array}$ & $\begin{array}{c}0.18 \\
(0.28)\end{array}$ & $\begin{array}{c}0.13 \\
(0.24)\end{array}$ & $\begin{array}{c}0.18 \\
(0.28)\end{array}$ & $\begin{array}{c}0.13 \\
(0.24)\end{array}$ & $\begin{array}{c}0.17 \\
(0.28)\end{array}$ \\
\hline EU controls & No & Yes & No & Yes & No & Yes & No & Yes & No & Yes & No & Yes \\
\hline U.K. controls & No & Yes & No & Yes & No & Yes & No & Yes & No & Yes & No & Yes \\
\hline Firm*Bank F.E. & Yes & Yes & Yes & Yes & Yes & Yes & Yes & Yes & Yes & Yes & Yes & Yes \\
\hline $\begin{array}{l}\text { State*Industry*Period } \\
\text { FE }\end{array}$ & Yes & Yes & Yes & Yes & Yes & Yes & Yes & Yes & Yes & Yes & Yes & Yes \\
\hline Observations & $4,309,232$ & $4,309,232$ & $4,309,232$ & $4,309,232$ & $4,309,232$ & $4,309,232$ & $4,309,232$ & $4,309,232$ & $4,309,232$ & $4,309,232$ & $4,309,232$ & $4,309,232$ \\
\hline R-squared & 0.03 & 0.04 & 0.03 & 0.04 & 0.03 & 0.04 & 0.03 & 0.04 & 0.03 & 0.04 & 0.03 & 0.04 \\
\hline
\end{tabular}

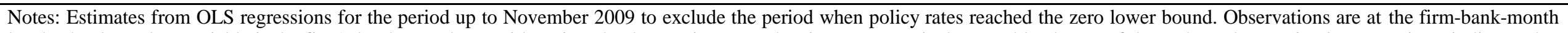

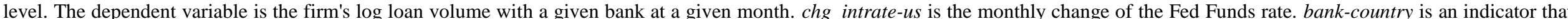

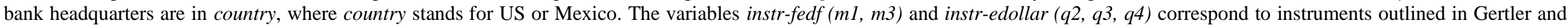

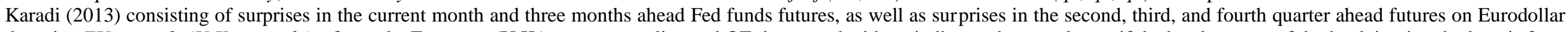

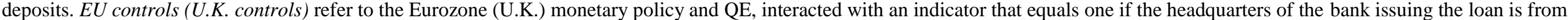

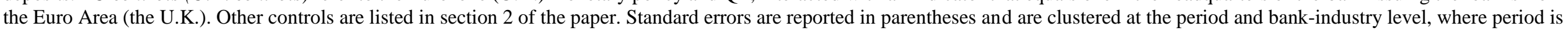
month. *significant at 10 percent, $* *$ significant at 5 percent, $* * *$ significant at 1 percent. 
Table A13. Impact of International Monetary Policies on Domestic Credit Margins (sample of five largest banks)

\begin{tabular}{|c|c|c|c|c|c|c|c|c|c|c|}
\hline & (1) & (2) & (3) & (4) & (5) & (6) & (7) & (8) & (9) & $(10)$ \\
\hline & \multicolumn{2}{|c|}{ Loan Volume } & \multicolumn{2}{|c|}{ Loan Maturity } & \multicolumn{2}{|c|}{ Loan Collateral } & \multicolumn{2}{|c|}{ Loan Rate } & \multicolumn{2}{|c|}{ Loan Default } \\
\hline \multirow[t]{2}{*}{ intrate-usr } & $-0.73 * * *$ & & $-2.54 * * *$ & & -0.15 & & $-0.05 * *$ & & -0.19 & \\
\hline & $(0.19)$ & & $(0.40)$ & & $(0.10)$ & & $(0.02)$ & & $(0.14)$ & \\
\hline \multirow[t]{2}{*}{ intrate-usr $*$ bank-us } & $-2.13 * * *$ & $-2.86 * * *$ & $-5.38 * * *$ & $-5.51 * * *$ & $-0.61 * * *$ & $-0.88 * * *$ & $0.04 *$ & $0.13 * * *$ & $-0.56 * * *$ & $-0.49 * *$ \\
\hline & $(0.27)$ & $(0.32)$ & $(0.67)$ & $(1.83)$ & $(0.18)$ & $(0.23)$ & $(0.02)$ & $(0.04)$ & $(0.13)$ & $(0.22)$ \\
\hline \multirow[t]{2}{*}{ intrate-ukr } & $-0.67 * *$ & & $-2.84 * * *$ & & $0.87 * * *$ & & $0.29 * * *$ & & $-1.01 * * *$ & \\
\hline & $(0.32)$ & & $(0.47)$ & & $(0.15)$ & & $(0.04)$ & & $(0.17)$ & \\
\hline \multirow[t]{2}{*}{ intrate-ukr * bank-uk } & -0.31 & $-1.69 * * *$ & $-8.62 * * *$ & $-8.98 * * *$ & $-1.51 * * *$ & $-1.30 * * *$ & $-0.14 * * *$ & -0.03 & $-1.08 * * *$ & $-0.87 * * *$ \\
\hline & $(0.49)$ & $(0.44)$ & $(0.66)$ & (1.06) & $(0.13)$ & $(0.19)$ & $(0.05)$ & $(0.08)$ & $(0.15)$ & $(0.18)$ \\
\hline \multirow[t]{2}{*}{ intrate-euror } & $1.96^{* * *}$ & & $2.50 * *$ & & $-0.72 * * *$ & & -0.09 & & $1.55 * * *$ & \\
\hline & $(0.48)$ & & $(1.16)$ & & $(0.24)$ & & $(0.08)$ & & $(0.32)$ & \\
\hline \multirow[t]{2}{*}{ intrate-euror $*$ bank-euro } & -0.52 & -0.32 & 0.48 & 1.74 & $-1.72 * * *$ & $-2.28 * * *$ & $-0.20 * * *$ & -0.07 & $-0.94 * * *$ & $-0.68 * *$ \\
\hline & $(0.66)$ & $(0.81)$ & $(1.09)$ & $(1.45)$ & $(0.41)$ & $(0.38)$ & $(0.06)$ & $(0.10)$ & $(0.21)$ & $(0.32)$ \\
\hline \multirow[t]{2}{*}{ intrate-mexr } & $-1.18 * * *$ & & $-1.82 * * *$ & & $-0.24 * *$ & & $0.16 * * *$ & & $-0.56 * * *$ & \\
\hline & $(0.20)$ & & $(0.40)$ & & $(0.11)$ & & $(0.03)$ & & $(0.12)$ & \\
\hline \multirow[t]{2}{*}{ intrate-mexr $*$ bank-mex } & -0.14 & 0.62 & $2.38 * * *$ & $2.83 * * *$ & $-0.89 * * *$ & $-0.75 * * *$ & 0.03 & -0.07 & $0.33 * * *$ & 0.28 \\
\hline & $(0.36)$ & $(0.57)$ & $(0.73)$ & $(1.06)$ & $(0.32)$ & $(0.28)$ & $(0.04)$ & $(0.07)$ & $(0.12)$ & $(0.24)$ \\
\hline \multirow[t]{2}{*}{ qe-us } & $-1.18 * * *$ & & $0.74 * * *$ & & 0.08 & & $-0.04 * * *$ & & $-0.35^{* *}$ & \\
\hline & $(0.18)$ & & $(0.22)$ & & $(0.08)$ & & $(0.02)$ & & $(0.16)$ & \\
\hline \multirow[t]{2}{*}{ qe-us * bank-us } & $0.85 * * *$ & $0.97 * * *$ & 0.57 & $2.58 * * *$ & -0.19 & 0.23 & $-0.14 * * *$ & $-0.10^{*}$ & -0.08 & 0.12 \\
\hline & $(0.24)$ & $(0.25)$ & $(0.61)$ & $(0.93)$ & $(0.14)$ & $(0.14)$ & $(0.03)$ & $(0.05)$ & $(0.08)$ & $(0.09)$ \\
\hline \multirow[t]{2}{*}{ qe-uk } & -0.16 & & -0.27 & & 0.04 & & $0.04 * * *$ & & $-0.22 * * *$ & \\
\hline & $(0.10)$ & & $(0.20)$ & & $(0.05)$ & & $(0.01)$ & & $(0.08)$ & \\
\hline \multirow[t]{2}{*}{ qe-uk $*$ bank-uk } & $0.73 * * *$ & $0.79 * *$ & $1.14 * * *$ & 0.71 & -0.03 & -0.02 & 0.07 & -0.01 & $0.13 *$ & 0.11 \\
\hline & $(0.21)$ & $(0.37)$ & $(0.35)$ & $(0.62)$ & $(0.07)$ & $(0.09)$ & $(0.05)$ & $(0.05)$ & $(0.07)$ & $(0.10)$ \\
\hline \multirow[t]{2}{*}{ qe-euro } & 0.10 & & $0.29 *$ & & $0.11 * * *$ & & $-0.03 * * *$ & & $0.33 * * *$ & \\
\hline & $(0.07)$ & & $(0.15)$ & & $(0.03)$ & & $(0.01)$ & & $(0.11)$ & \\
\hline \multirow[t]{2}{*}{ qe-euro $*$ bank-euro } & $0.44 * * *$ & 0.26 & $0.45 * *$ & 0.01 & $0.52 * * *$ & $0.23 * * *$ & 0.00 & $0.03 * *$ & 0.12 & 0.05 \\
\hline & $(0.12)$ & $(0.17)$ & $(0.20)$ & $(0.30)$ & $(0.09)$ & $(0.08)$ & $(0.01)$ & $(0.01)$ & $(0.11)$ & $(0.11)$ \\
\hline Observations & $6,476,960$ & $6,476,960$ & $6,476,960$ & $6,476,960$ & $6,476,960$ & $6,476,960$ & $6,476,960$ & $6,476,960$ & $4,690,739$ & $4,690,739$ \\
\hline R-squared & 0.01 & 0.03 & 0.16 & 0.20 & 0.01 & 0.04 & 0.19 & 0.25 & 0.01 & 0.03 \\
\hline
\end{tabular}


Table A14. Impact of International Monetary Policies on Credit Margins (controlling for Sovereign Credit Default Swaps of the U.K., U.S. and Eurozone)

\begin{tabular}{|c|c|c|c|c|c|c|c|c|c|c|}
\hline & (1) & (2) & (3) & (4) & (5) & (6) & (7) & (8) & (9) & $(10)$ \\
\hline & \multicolumn{2}{|c|}{ Loan Volume } & \multicolumn{2}{|c|}{ Loan Maturity } & \multicolumn{2}{|c|}{ Loan Collateral } & \multicolumn{2}{|c|}{ Loan Rate } & \multicolumn{2}{|c|}{ Loan Default } \\
\hline \multirow[t]{2}{*}{ intrate-fgnr*share-fgn } & $-1.70 * * *$ & $-1.49 * * *$ & $-4.64 * * *$ & $-4.89 * * *$ & $-1.23 * * *$ & $-1.14 * * *$ & $0.10 * * *$ & $0.09 * * *$ & $-0.25 * * *$ & $-0.26 * * *$ \\
\hline & $(0.23)$ & $(0.22)$ & $(0.60)$ & $(0.64)$ & $(0.20)$ & $(0.21)$ & $(0.02)$ & $(0.02)$ & $(0.08)$ & $(0.08)$ \\
\hline \multirow[t]{2}{*}{ intrate-mexr*share-mex } & 0.43 & $0.52 * *$ & $2.09 * *$ & $2.16 * *$ & -0.19 & -0.17 & $-0.07 * * *$ & $-0.07 * * *$ & 0.29 & 0.28 \\
\hline & $(0.26)$ & $(0.24)$ & $(0.96)$ & $(0.95)$ & $(0.62)$ & $(0.63)$ & $(0.03)$ & $(0.03)$ & $(0.19)$ & $(0.19)$ \\
\hline \multirow[t]{2}{*}{ qe-fgn*share-fgn } & $0.22 * *$ & $0.37 *$ & $1.04 * * *$ & $1.76 * * *$ & $0.11 * *$ & 0.09 & $0.04 * * *$ & $0.05 * *$ & $0.15 * * *$ & $0.13 * *$ \\
\hline & $(0.10)$ & $(0.19)$ & $(0.20)$ & $(0.32)$ & $(0.05)$ & $(0.08)$ & $(0.01)$ & $(0.02)$ & $(0.04)$ & $(0.06)$ \\
\hline \multirow[t]{2}{*}{$c d s^{*}$ share-fgn } & & $0.02 * * *$ & & $-0.01 * * *$ & & $0.01 * * *$ & & $-0.00 * *$ & & -0.00 \\
\hline & & $(0.00)$ & & $(0.00)$ & & $(0.00)$ & & $(0.00)$ & & $(0.00)$ \\
\hline \multirow[t]{2}{*}{$q e-f g n^{*} c d s^{*}$ share-fgn } & & $-0.17 * *$ & & $-0.40 * * *$ & & -0.01 & & -0.00 & & 0.04 \\
\hline & & $(0.08)$ & & $(0.11)$ & & $(0.02)$ & & $(0.01)$ & & $(0.04)$ \\
\hline Firm F.E. & Yes & Yes & Yes & Yes & Yes & Yes & Yes & Yes & Yes & Yes \\
\hline State*Industry*Period F.E. & Yes & Yes & Yes & Yes & Yes & Yes & Yes & Yes & Yes & Yes \\
\hline Observations & $5,852,277$ & $5,852,277$ & $5,852,277$ & $5,852,277$ & $5,852,277$ & $5,852,277$ & $5,852,277$ & $5,852,277$ & $4,682,443$ & $4,682,443$ \\
\hline R-squared & 0.03 & 0.03 & 0.12 & 0.13 & 0.04 & 0.04 & 0.17 & 0.18 & 0.03 & 0.03 \\
\hline
\end{tabular}

Notes: Estimates from OLS regressions. Observations are at the firm-month level. The dependent variables are a firm's: log total loan volume, log maturity, collateral rate, loan interest rate and default rate 12-months ahead with a given bank in a given month. intrate-fgnr is the average of the residual of foreign overnight rates, weighted

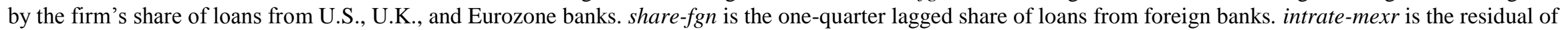
Mexican overnight rate. share-mex is the one-quarter lagged share of loans from Mexican banks. qe-fgn is the average of foreign QEs, weighted by the firm's share of loans from U.S., U.K., or Eurozone banks. $c d s$ is the average level of the foreign Sovereign Credit Default Swaps, weighted by the firm's share of loans from U.S., U.K., and Eurozone banks. Other controls are listed in section 2 of the paper. Standard errors are reported in parentheses and are clustered at the period level. *significant at 10 percent, $* *$ significant at 5 percent, ***significant at 1 percent. 
Table A15. Asymmetric Impact of Expansions and Contractions of International Monetary Policies on Domestic Credit Margins

\begin{tabular}{|c|c|c|c|c|c|}
\hline & $\begin{array}{c}(1) \\
\text { Loan } \\
\text { Volume }\end{array}$ & $\begin{array}{c}(2) \\
\text { Loan } \\
\text { Maturity }\end{array}$ & $\begin{array}{c}(3) \\
\text { Loan } \\
\text { Collateral } \\
\end{array}$ & $\begin{array}{l}(4) \\
\text { Loan } \\
\text { Rate }\end{array}$ & $\begin{array}{c}(5) \\
\text { Loan } \\
\text { Default }\end{array}$ \\
\hline intrate-fgnr*share-fgn & $\begin{array}{c}-2.11 * * * \\
(0.56)\end{array}$ & $\begin{array}{c}-3.18 * * \\
(1.48)\end{array}$ & $\begin{array}{c}-1.91 * * * \\
(0.38)\end{array}$ & $\begin{array}{l}0.22 * * \\
(0.10)\end{array}$ & $\begin{array}{c}-0.36^{* *} \\
(0.18)\end{array}$ \\
\hline intrate-fgnr*share-fgn*I( $\left.\exp _{\text {intfrn }}\right)$ & $\begin{array}{c}1.97 \\
(1.38)\end{array}$ & $\begin{array}{l}-3.76 \\
(3.38)\end{array}$ & $\begin{array}{c}2.74 * * * \\
(0.83)\end{array}$ & $\begin{array}{l}-0.28 \\
(0.17)\end{array}$ & $\begin{array}{c}0.16 \\
(0.52)\end{array}$ \\
\hline intrate-mexr*share-mex & $\begin{array}{c}0.50 \\
(1.36)\end{array}$ & $\begin{array}{l}2.08^{*} \\
(1.14)\end{array}$ & $\begin{array}{c}0.06 \\
(0.87)\end{array}$ & $\begin{array}{l}-0.12 \\
(0.15)\end{array}$ & $\begin{array}{c}0.28 \\
(0.35)\end{array}$ \\
\hline intrate-mexr*share-mex $* I\left(\exp _{\text {intdom }}\right)$ & $\begin{array}{c}2.17 \\
(7.06)\end{array}$ & $\begin{array}{c}0.20 \\
(1.74)\end{array}$ & $\begin{array}{c}1.61 * * * \\
(0.53)\end{array}$ & $\begin{array}{c}0.17 \\
(0.21)\end{array}$ & $\begin{array}{c}0.35 \\
(0.45)\end{array}$ \\
\hline qe-fgn*share-fgn & $\begin{array}{l}0.99 * * \\
(0.43)\end{array}$ & $\begin{array}{c}0.98 \\
(0.96)\end{array}$ & $\begin{array}{c}0.12 \\
(0.32)\end{array}$ & $\begin{array}{l}-0.09 * \\
(0.05)\end{array}$ & $\begin{array}{c}0.60 \\
(0.64)\end{array}$ \\
\hline qe-fgn*share-fgn $* I\left(\exp _{q e}\right)$ & $\begin{array}{l}-0.42 \\
(0.61)\end{array}$ & $\begin{array}{c}0.40 \\
(1.38)\end{array}$ & $\begin{array}{l}-0.13 \\
(0.43)\end{array}$ & $\begin{array}{c}0.05 \\
(0.09)\end{array}$ & $\begin{array}{c}1.04 * * * \\
(0.35)\end{array}$ \\
\hline $\begin{array}{l}\text { Firm F.E. } \\
\text { State*Industry*Period F.E. }\end{array}$ & $\begin{array}{l}\text { Yes } \\
\text { Yes }\end{array}$ & $\begin{array}{l}\text { Yes } \\
\text { Yes }\end{array}$ & $\begin{array}{l}\text { Yes } \\
\text { Yes }\end{array}$ & $\begin{array}{l}\text { Yes } \\
\text { Yes }\end{array}$ & $\begin{array}{l}\text { Yes } \\
\text { Yes }\end{array}$ \\
\hline $\begin{array}{l}\text { Observations } \\
\text { R-squared }\end{array}$ & $\begin{array}{c}5,852,277 \\
0.04\end{array}$ & $\begin{array}{c}5,852,277 \\
0.13\end{array}$ & $\begin{array}{c}5,852,277 \\
0.05\end{array}$ & $\begin{array}{c}5,852,277 \\
0.18\end{array}$ & $\begin{array}{c}4,682,443 \\
0.03\end{array}$ \\
\hline $\begin{array}{l}\text { Notes: Estimates from OLS regressions } \\
\text { maturity, collateral rate, loan rate and d } \\
\text { foreign overnight rates, weighted by the } \\
\text { from foreign banks. intrate-mexr is the } r \\
\text { fgn is the average of foreign QEs, weigh } \\
\text { equals one if the residual of the overnigh } \\
\text { of central bank assets, weighted by the } \mathrm{f} \\
\text { Standard errors are reported in parenthes } \\
\text { percent. }\end{array}$ & $\begin{array}{l}\text { ervations are } \\
\text { rate } 12 \text {-mon } \\
\text { 's share of lo } \\
\text { al of Mexican } \\
\text { y the firm's s } \\
\text { of country il } \\
\text { exposure to } 1 \\
d \text { are clustere }\end{array}$ & $\begin{array}{l}\text { irm-month le } \\
\text { with a giver } \\
\text { U.S., U.K., } \\
\text { ht rate. share } \\
\text { oans from U. } \\
\text { t is positive. } \\
\text { m banks from } \\
\text { eriod level. * }\end{array}$ & $\begin{array}{l}\text { lependent va } \\
\text { a given mon } \\
\text { ne banks. sh } \\
\text { one-quarter } \\
\text { or Eurozone } \\
\text { an indicator } \\
\text { countries. O } \\
t \text { at } 10 \text { perce }\end{array}$ & $\begin{array}{l}\text { are: a firm's } \\
\text { te-fgnr is the } \\
\text { is the one-qu } \\
\text { share of loan } \\
\text { (exp intcountry) } \\
\text { itive annual } \\
\text { trols are liste } \\
\text { nificant at } 5\end{array}$ & $\begin{array}{l}\text { an volume, log } \\
\mathrm{f} \text { the residual of } \\
\mathrm{d} \text { share of loans } \\
\text { kican banks. qe- } \\
\text { tor variable that } \\
\text { in the net value } \\
2 \text { of the paper. } \\
\text { * significant at } 1\end{array}$ \\
\hline
\end{tabular}


Table A16. Impact of Various Lags of International Monetary Policies on Domestic Credit Margins and Future Default (Firm Level)

\begin{tabular}{|c|c|c|c|c|c|c|c|c|c|c|c|c|c|c|c|}
\hline & (1) & (2) & (3) & (4) & (5) & (6) & (7) & $(8)$ & (9) & (10) & $(11)$ & (12) & (13) & (14) & $(15)$ \\
\hline & \multicolumn{3}{|c|}{ Loan Volume } & \multicolumn{3}{|c|}{ Loan Maturity } & \multicolumn{3}{|c|}{ Loan Collateral } & \multicolumn{3}{|c|}{ Loan Rate } & \multicolumn{3}{|c|}{ Loan Default } \\
\hline & $3 \mathrm{~m} \mathrm{lag}$ & $6 \mathrm{~m}$ lag & $12 \mathrm{~m} \mathrm{lag}$ & $3 \mathrm{~m}$ lag & $6 \mathrm{~m} \mathrm{lag}$ & $12 \mathrm{~m} \mathrm{lag}$ & $3 \mathrm{~m} \mathrm{lag}$ & $6 \mathrm{~m}$ lag & $12 \mathrm{~m} \mathrm{lag}$ & $3 \mathrm{~m}$ lag & $6 \mathrm{~m}$ lag & $\begin{array}{c}12 \mathrm{~m} \\
\mathrm{lag}\end{array}$ & $3 \mathrm{~m}$ lag & $6 \mathrm{~m}$ lag & $12 \mathrm{~m} \mathrm{lag}$ \\
\hline intrate-fgnr & $-1.70 * * *$ & $-1.86 * * *$ & $-1.70 * * *$ & $-4.64 * * *$ & $-4.43 * * *$ & $-4.64 * * *$ & $-1.23 * * *$ & $-1.22 * * *$ & $-1.09 * * *$ & $0.10^{* * *}$ & $0.14 * * *$ & $0.25^{* * * *}$ & $-0.25 * * *$ & $-0.18^{* *}$ & 0.01 \\
\hline *share-fgn & $(0.23)$ & $(0.24)$ & $(0.29)$ & $(0.60)$ & $(0.66)$ & $(0.60)$ & $(0.20)$ & $(0.19)$ & $(0.20)$ & $(0.02)$ & $(0.02)$ & $(0.03)$ & $(0.08)$ & $(0.08)$ & $(0.08)$ \\
\hline intrate-mexr & 0.43 & 0.53 & $-0.67 * *$ & $2.09 * *$ & $2.52^{* * * *}$ & $2.09 * *$ & -0.19 & 0.07 & $1.00 *$ & $-0.07 * * *$ & -0.01 & $0.07 * * *$ & 0.29 & 0.27 & 0.29 \\
\hline *share-mex & $(0.26)$ & $(0.37)$ & $(0.26)$ & $(0.96)$ & $(0.96)$ & $(0.96)$ & $(0.62)$ & $(0.60)$ & $(0.55)$ & $(0.03)$ & $(0.03)$ & $(0.02)$ & $(0.19)$ & $(0.20)$ & $(0.18)$ \\
\hline qe-fgn & $0.22 * *$ & $0.48^{* * *}$ & $0.72^{* * *}$ & $1.04 * * *$ & $1.39 * * *$ & $1.04 * * *$ & $0.11 * *$ & $0.11^{* *}$ & $0.13 * *$ & $0.04 * * *$ & $0.03 * *$ & 0.01 & $0.15^{* * *}$ & $0.12 * * *$ & $0.09^{* * *}$ \\
\hline *share-fgn & $(0.10)$ & $(0.10)$ & $(0.12)$ & $(0.20)$ & $(0.21)$ & $(0.20)$ & $(0.05)$ & $(0.05)$ & $(0.05)$ & $(0.01)$ & $(0.01)$ & $(0.01)$ & $(0.04)$ & $(0.04)$ & $(0.03)$ \\
\hline Firm F.E. & Yes & Yes & Yes & Yes & Yes & Yes & Yes & Yes & Yes & Yes & Yes & Yes & Yes & Yes & Yes \\
\hline S*I*P F.E. & Yes & Yes & Yes & Yes & Yes & Yes & Yes & Yes & Yes & Yes & Yes & Yes & Yes & Yes & Yes \\
\hline Obs. & $5,852,277$ & $5,852,277$ & $5,852,277$ & $5,852,277$ & $5,852,277$ & $5,852,277$ & $5,852,277$ & $5,852,277$ & $5,852,277$ & $5,852,277$ & $5,852,277$ & $5,852,277$ & $4,682,443$ & $4,682,443$ & $4,682,443$ \\
\hline R-squared & 0.03 & 0.03 & 0.03 & 0.12 & 0.12 & 0.12 & 0.04 & 0.04 & 0.04 & 0.17 & 0.18 & 0.19 & 0.03 & 0.03 & 0.03 \\
\hline
\end{tabular}

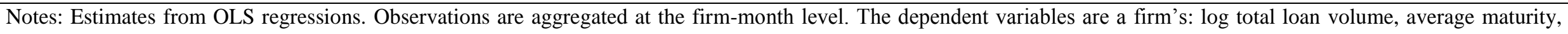

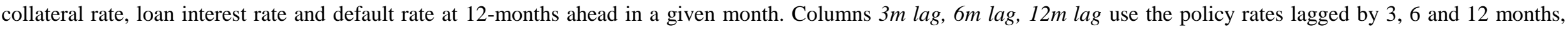

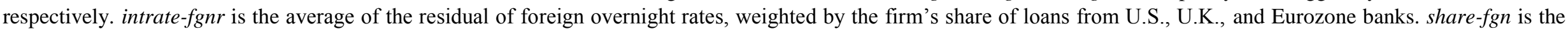

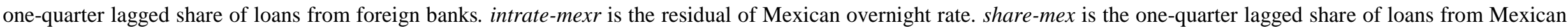

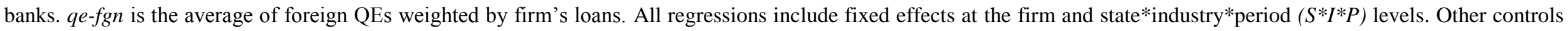

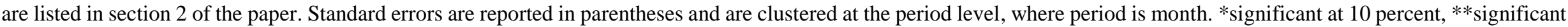
at 5 percent, ***significant at 1 percent. 
Table A17. Impact of Lagged-1-year International Monetary Policies on Real Variables of Domestic Firms

\begin{tabular}{|c|c|c|c|c|c|c|c|}
\hline & (1) & (2) & (3) & (4) & (5) & (6) & (7) \\
\hline & Exit & Liabilities & $\begin{array}{c}\text { Current } \\
\text { Liabilities } \\
\end{array}$ & $\begin{array}{c}\text { Non-Current } \\
\text { Liabilities }\end{array}$ & Assets & Fixed Assets & Employment \\
\hline \multirow[t]{2}{*}{ intrate $^{\mathrm{Y}-1}$-fgnr*share ${ }^{\mathrm{Y}}$-fgn } & $0.88^{*}$ & $-1.22 * *$ & $-1.34 * *$ & $-1.32 * *$ & $-0.64 *$ & -0.00 & $-0.39 *$ \\
\hline & $(0.54)$ & $(0.41)$ & $(0.42)$ & $(0.49)$ & $(0.37)$ & $(0.37)$ & $(0.23)$ \\
\hline \multirow[t]{2}{*}{ intrate $^{\mathrm{Y}-1}-$ mexr $^{*}$ share $^{\mathrm{Y}}$-mex } & -0.21 & 0.46 & 1.02 & -2.02 & $0.74 * *$ & $0.96 * * *$ & 0.30 \\
\hline & $(0.75)$ & $(0.80)$ & $(0.71)$ & $(2.69)$ & $(0.29)$ & $(0.28)$ & $(0.62)$ \\
\hline \multirow[t]{2}{*}{$\mathrm{qe}^{\mathrm{Y}-1}$-fgn*share ${ }^{\mathrm{Y}}$-fgn } & -0.13 & 0.03 & -0.14 & $1.78 *$ & 0.31 & 0.82 & -0.12 \\
\hline & $(0.09)$ & $(0.43)$ & $(0.47)$ & $(0.92)$ & $(0.29)$ & $(0.46)$ & $(0.11)$ \\
\hline Firm F.E. & Yes & Yes & Yes & Yes & Yes & Yes & Yes \\
\hline Observations & 744,221 & 13,945 & 13,918 & 6,923 & 14,563 & 14,563 & 13,838 \\
\hline R-squared & 0.04 & 0.20 & 0.20 & 0.25 & 0.26 & 0.22 & 0.19 \\
\hline
\end{tabular}

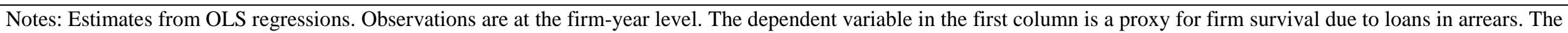

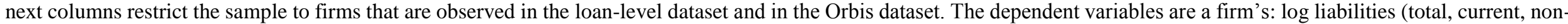

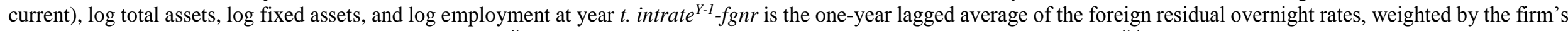

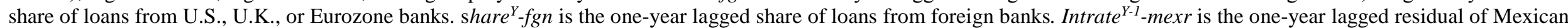

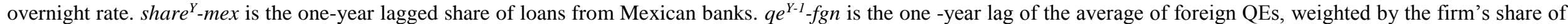

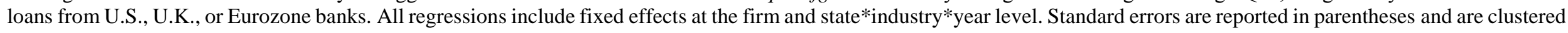
at the state*year level. *significant at 10 percent, **significant at 5 percent, ***significant at 1 percent. 
Table A18. Impact of International Monetary Policies on Real Variables re-scaled by Initial Local Firm Assets

\begin{tabular}{|c|c|c|c|}
\hline & $\begin{array}{c}(1) \\
\text { Loan Volume }\end{array}$ & $\begin{array}{c}\text { (2) } \\
\text { Liabilities }\end{array}$ & $\begin{array}{c}(3) \\
\text { Assets }\end{array}$ \\
\hline intrate $^{\mathrm{Y}}$-fgnr* share $^{\mathrm{Y}}$-fgn & $\begin{array}{l}-1.64 * \\
(0.94)\end{array}$ & $\begin{array}{c}-1.03 * * \\
(0.43)\end{array}$ & $\begin{array}{c}-0.69 * * \\
(0.32)\end{array}$ \\
\hline intrate $^{\mathrm{Y}}$-mexr*share ${ }^{\mathrm{Y}}$-mex & $\begin{array}{l}-0.03 \\
(1.26)\end{array}$ & $\begin{array}{c}0.38 \\
(0.75)\end{array}$ & $\begin{array}{c}0.66 \\
(0.50)\end{array}$ \\
\hline $\mathrm{qe}^{\mathrm{Y}}$-fgn* share $^{\mathrm{Y}}$-fgn & $\begin{array}{c}0.35 \\
(0.33)\end{array}$ & $\begin{array}{c}0.22 \\
(0.23)\end{array}$ & $\begin{array}{c}0.17 \\
(0.21)\end{array}$ \\
\hline $\begin{array}{l}\text { Firm F.E. } \\
\text { State*Industry*Year F.E. }\end{array}$ & $\begin{array}{l}\text { Yes } \\
\text { Yes }\end{array}$ & $\begin{array}{l}\text { Yes } \\
\text { Yes }\end{array}$ & $\begin{array}{l}\text { Yes } \\
\text { Yes }\end{array}$ \\
\hline $\begin{array}{l}\text { Observations } \\
\text { R-squared }\end{array}$ & $\begin{array}{c}42,574 \\
0.24\end{array}$ & $\begin{array}{c}13,943 \\
0.20\end{array}$ & $\begin{array}{c}14,563 \\
0.26\end{array}$ \\
\hline
\end{tabular}

Notes: Estimates from OLS regressions. Observations are at the firm-year level for the sample of firms matched with Orbis data. The dependent variables are a firm's: log loan volume, log liabilities and log total assets, re-scaled by the firm's initial assets. intrate$f g n r$ is the average of the residual of foreign overnight rates weighted by firm's loans. share-fgn is the one-quarter lagged share of loans from foreign banks. intrate-mexr is the residual of Mexican overnight rate. share-mex is the one-quarter lagged share of loans from Mexican banks. qe-fgn is the average of foreign QEs weighted by firm's loans. All regressions include fixed effects at the firm, state*industry*year level. Standard errors are reported in parentheses and are clustered at the state*year level. *significant at 10 percent, $* *$ significant at 5 percent, $* * *$ significant at 1 percent. 
Table A19. Impact of International Monetary Policies on Real Variables of Small versus Large Domestic Firms

\begin{tabular}{|c|c|c|c|c|c|c|c|}
\hline & $\begin{array}{l}(1) \\
\text { Exit }\end{array}$ & $\begin{array}{c}(2) \\
\text { Liabilities }\end{array}$ & $\begin{array}{c}(3) \\
\text { Current } \\
\text { Liabilities }\end{array}$ & $\begin{array}{c}(4) \\
\text { Non-Current } \\
\text { Liabilities }\end{array}$ & $\begin{array}{c}(5) \\
\text { Assets }\end{array}$ & $\begin{array}{c}(6) \\
\text { Fixed Assets }\end{array}$ & $\begin{array}{c}(7) \\
\text { Employment }\end{array}$ \\
\hline intrate $^{Y}$-fgnr* share $^{Y}$-fgn $*$ small & $\begin{array}{l}1.32 * \\
(0.73)\end{array}$ & $\begin{array}{c}-1.39 * * \\
(0.49)\end{array}$ & $\begin{array}{c}-1.37 * * \\
(0.43)\end{array}$ & $\begin{array}{c}-3.34 * * \\
(1.16)\end{array}$ & $\begin{array}{c}-1.04 * * \\
(0.42)\end{array}$ & $\begin{array}{l}-0.40^{*} \\
(0.24)\end{array}$ & $\begin{array}{l}-0.53 \\
(0.34)\end{array}$ \\
\hline intrate $^{\mathrm{Y}}$-fgnr* share $^{\mathrm{Y}}$-fgn $*$ large & $\begin{array}{l}-0.06 \\
(0.22)\end{array}$ & $\begin{array}{l}-0.49 \\
(0.56)\end{array}$ & $\begin{array}{l}-0.89 \\
(0.67)\end{array}$ & $\begin{array}{c}0.83 \\
(1.14)\end{array}$ & $\begin{array}{c}0.25 \\
(0.56)\end{array}$ & $\begin{array}{c}0.23 \\
(0.62)\end{array}$ & $\begin{array}{l}-0.61 \\
(0.72)\end{array}$ \\
\hline intrate $^{\mathrm{Y}}$-mexr* share $^{\mathrm{Y}}$-mex $*$ small & $\begin{array}{c}-1.40 * * * \\
(0.36)\end{array}$ & $\begin{array}{c}0.76 \\
(0.67)\end{array}$ & $\begin{array}{l}1.49 * * \\
(0.57)\end{array}$ & $\begin{array}{l}-5.97 \\
(4.73)\end{array}$ & $\begin{array}{l}0.78 * \\
(0.37)\end{array}$ & $\begin{array}{c}1.72 * * * \\
(0.25)\end{array}$ & $\begin{array}{l}-0.74 \\
(1.52)\end{array}$ \\
\hline intrate $^{\mathrm{Y}}$-mexr* share $^{\mathrm{Y}}$-mex $*$ large & $\begin{array}{c}0.78 \\
(1.26)\end{array}$ & $\begin{array}{c}0.24 \\
(0.68)\end{array}$ & $\begin{array}{c}0.57 \\
(0.55)\end{array}$ & $\begin{array}{c}1.53 \\
(3.20)\end{array}$ & $\begin{array}{l}0.96 * * \\
(0.40)\end{array}$ & $\begin{array}{c}0.89 * * * \\
(0.20)\end{array}$ & $\begin{array}{c}0.78 \\
(0.57)\end{array}$ \\
\hline $\mathrm{qe}^{\mathrm{Y}}$-fgn*share ${ }^{\mathrm{Y}}$-fgn $*$ small & $\begin{array}{c}0.01 \\
(0.12)\end{array}$ & $\begin{array}{c}0.19 \\
(0.21)\end{array}$ & $\begin{array}{c}0.06 \\
(0.20)\end{array}$ & $\begin{array}{c}1.40 * * \\
(0.49)\end{array}$ & $\begin{array}{c}0.16 \\
(0.22)\end{array}$ & $\begin{array}{c}0.65 * * * \\
(0.19)\end{array}$ & $\begin{array}{c}0.04 \\
(0.23)\end{array}$ \\
\hline $\mathrm{qe}^{\mathrm{Y}}$-fgn*share ${ }^{\mathrm{Y}}$-fgn $*$ large & $\begin{array}{c}0.10 \\
(0.11)\end{array}$ & $\begin{array}{c}0.09 \\
(0.39)\end{array}$ & $\begin{array}{c}0.09 \\
(0.51)\end{array}$ & $\begin{array}{c}-1.65 * * * \\
(0.39)\end{array}$ & $\begin{array}{c}0.00 \\
(0.27)\end{array}$ & $\begin{array}{c}0.68 \\
(0.43)\end{array}$ & $\begin{array}{l}-0.26 \\
(0.22)\end{array}$ \\
\hline Firm F.E. & Yes & Yes & Yes & Yes & Yes & Yes & Yes \\
\hline $\begin{array}{l}\text { State*Industry* Year F.E. } \\
\text { Observations }\end{array}$ & $\begin{array}{c}\text { Yes } \\
734,309\end{array}$ & $\begin{array}{c}\text { Yes } \\
13,898\end{array}$ & $\begin{array}{c}\text { Yes } \\
13,871\end{array}$ & $\begin{array}{c}\text { Yes } \\
6,882\end{array}$ & $\begin{array}{c}\text { Yes } \\
14,471\end{array}$ & $\begin{array}{c}\text { Yes } \\
14,471\end{array}$ & $\begin{array}{c}\text { Yes } \\
13,823\end{array}$ \\
\hline R-squared & 0.03 & 0.20 & 0.20 & 0.26 & 0.26 & 0.22 & 0.20 \\
\hline
\end{tabular}

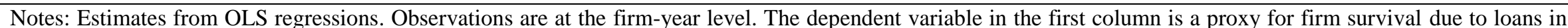

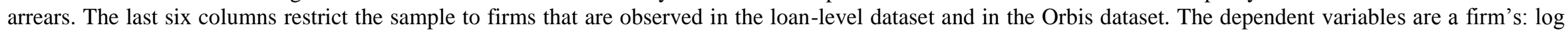

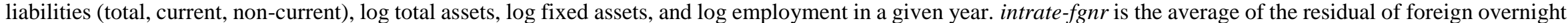

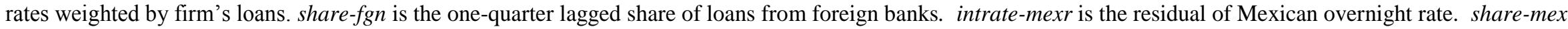

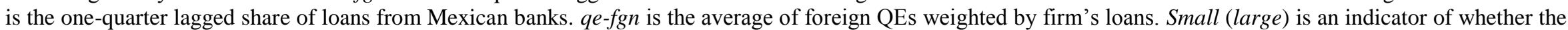

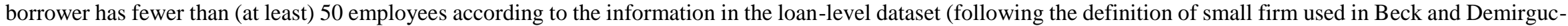

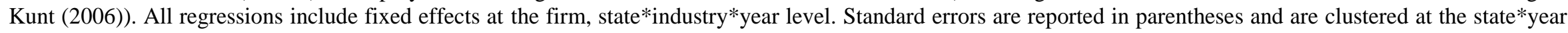
level. *significant at 10 percent, **significant at 5 percent, ***significant at 1 percent. 